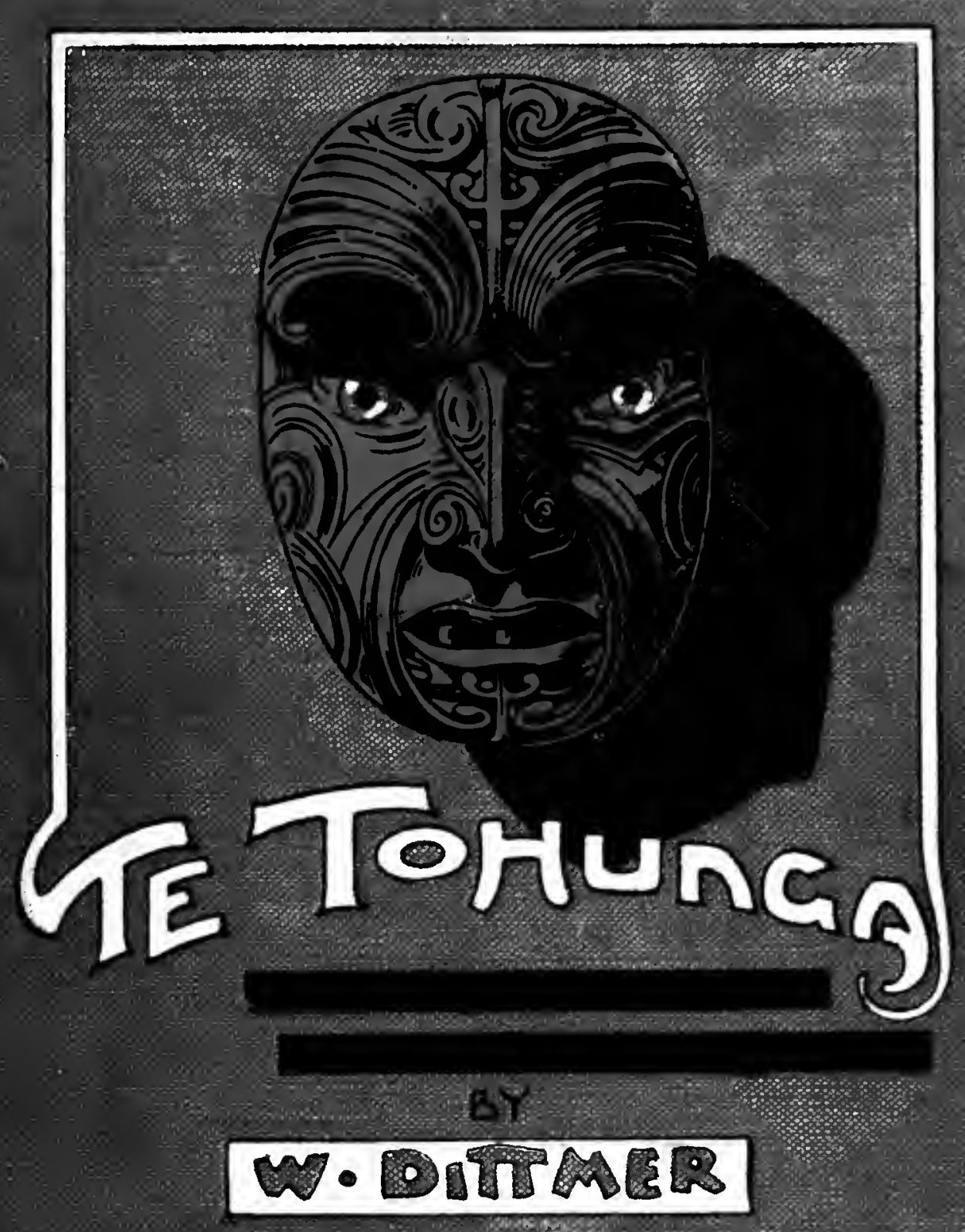




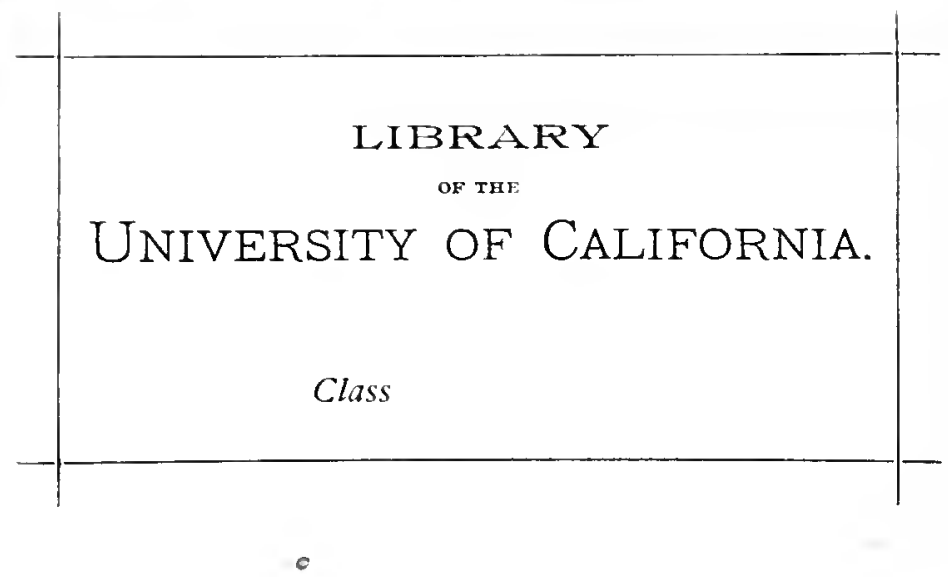

I 


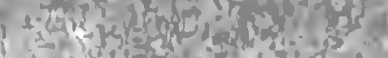


A

MEMORIAL

To

THE RT. HON. R. J. SEDDON, P.C.

Premier of New Zealand, 1893-1906 

TE TOHUNGA 


\section{Digitized by the Internet Archive in 2007 with funding from Microsoft Corporation}





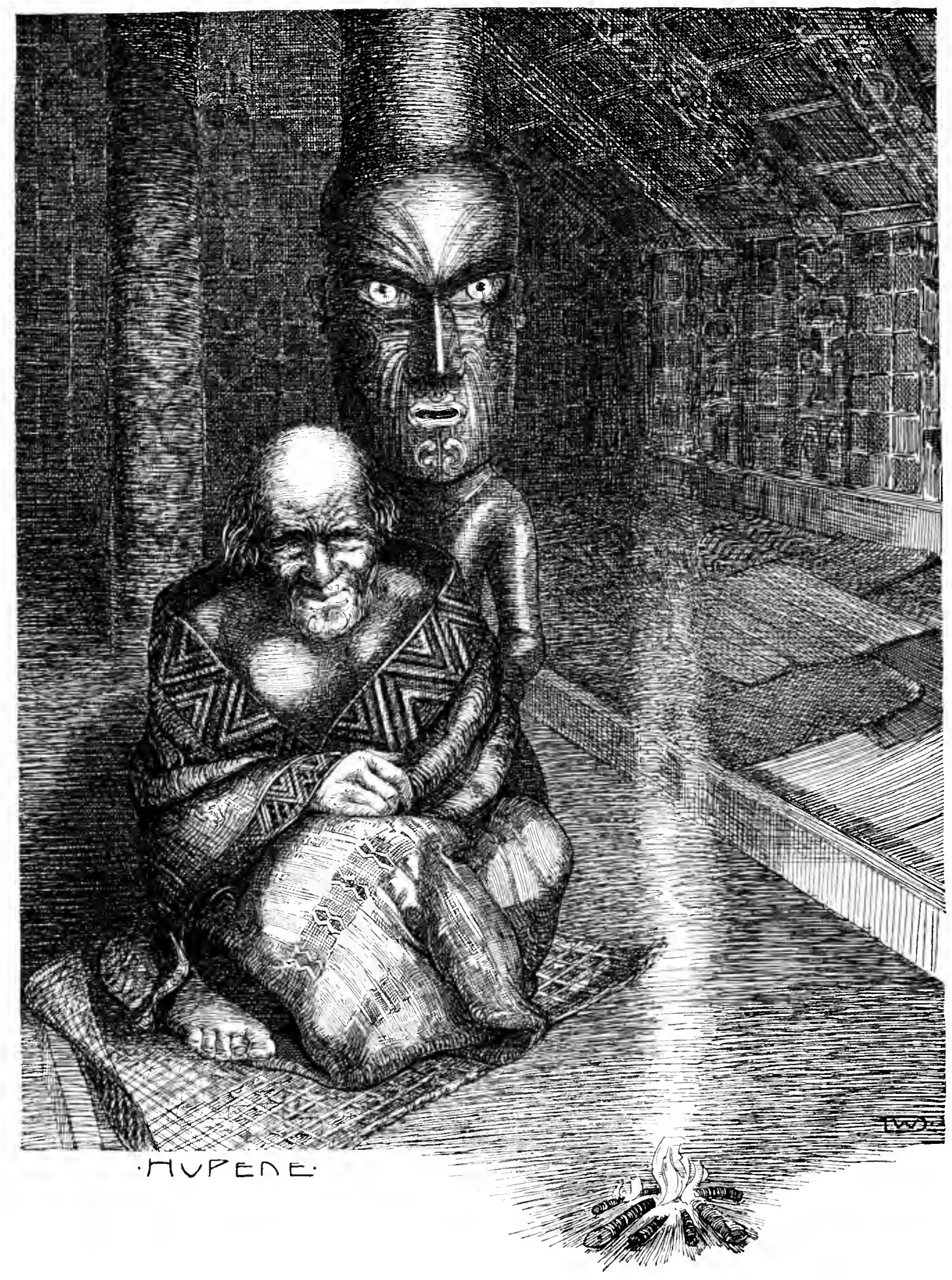




\title{
T'E TOHUNGA
}

\section{THE ANCIENT LEGENDS AND TRADITIONS OF THE MAORIS}

\author{
ORALLY COLLECTED AND PICTURED \\ BY \\ W. DITTIMER
}

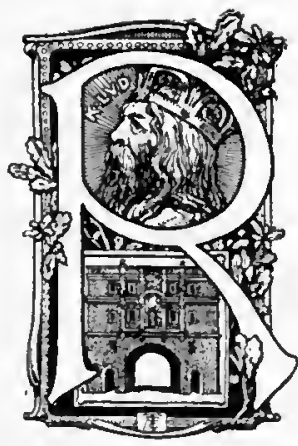

LON DON

GEORGE ROUTLEDGE \& SONS, LIMITED

NEW YORK : E. P. DUTTON \& CO. 
Nau i waka aua te kakahu, he taniko taku

(You wove the garment, I have put the border to it)

Maori Proverb

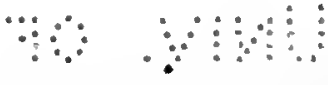




\section{THE COUNTESS OF RANFURLY}

Who was a true friend to Artists and

their Art in New Zealand

This Book is Dedicated

By the Author 


\section{LIST OF CONTENTS}

CHAP.

INTRODUCTION. With 2 Illustrations .

PAGE

I. TIKI-THE ANCESTOR OF MANKIND. With 3 Illustrations . . . . . . . 5

II. THE CREATION OF HAWAIKI. With 3 Illustrations.$\quad$. $\quad . \quad$. $\quad . \quad$. $\quad$. 9

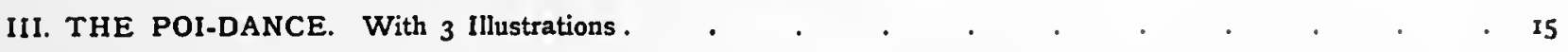

IV. THE CREATION OF THE STARS. With 5 Illustrations. . . . . . . . . . 20

V. THE CHANT OF RANGI-NUI. With 2 Illustrations . . . . . . . . . . . 26

VI. TANE-THE CREATION OF NATURE. With 2 Illustrations . . . . . . . . . 30

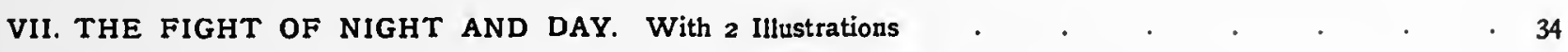

VIII. MAUI-THE CREATION OF NEW ZEALAND. With 6 Illustrations _ . • . . . 37

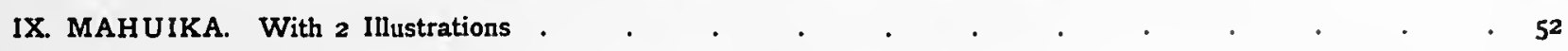

X. MAUI AND MAHUIKA; MAUI'S FIGHT WITH THE SUN. With 3 Illustrations . . . 56

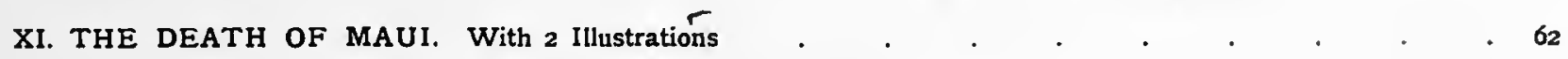

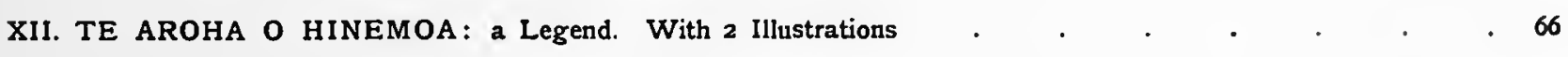

XIII. MAUI AND IRAWARU : a Tradition. With I Illustration. . . . . . . . . . $7 I$

XIV. NGA PATU-PAIAREHE, THE CHILDREN OF THE MIST [by James Cowan]. With 3 Illustrations 74

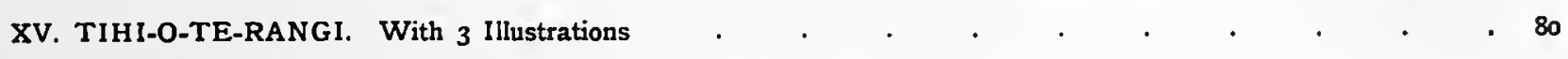

XV1. THE BATTLE OF THE GIANTS. With 3 lllustrations . . . . . . . . . • • 86

XVII. THE COMING OF THE MAORI [by James Cowan]. With 3 Illustrations . . . . ..93

XVIII. TRADITION-TAMA-TE-KAPUA. With 4 Illustrations . . . . . . . . . . I00

XIX. A TANGI. TE REINGA [by James Cowan]. With 3 Illustrations . . . . . . . $\quad$ ro7

XX. NGAWAI. THE BURIAL OF TE HEU-HEU ON TONGARIRO. With 4 Illustrations . . . Ir4 


\section{LIST OF FULL-PAGE ILLUSTRATIONS}

1. HUPENE, THE OLD TOHUNGA

PAGE

2. MATAPO, A BLIND TOHUNGA

Frontispiece

3. TANE, THE GOD OF TREES

4. THE BIRTH OF MAUI AT MAHIKU-RANGI

5. TANE SEARCHING FOR THE DWELLING OF THE EVENING STAR AND THE MORNING STAR 21

6. NGAWAI, A MAORI CHIEFTAINESS

7. TANE AND THE TREES

8. MAUI ENTERS HINE-NUI-TE-PO'S PATAKA

9. MAUI .

10. A TOHUNGA

11. MAUI CHANTING INCANTATIONS

12. MAUI FISHING NEW ZEALAND OUT OF THE OCEAN.

13. TARANGA, THE NIGHT-SUN, AND MAUI

14. MAUI'S FIGHT WITH THE SUN .

15. HINE-NUI-TE-PO KILLING MAUI .

I6. HINEMOA

17. MAUI AND IRAWARU .

18. THE MAORIS AND THE FAIRY PEOPLE . . . . . . . . . . . . . 77

19. A TANGI

20. A GIANT

21. THE BATTLE

22. HAWAIKI

23. THE JOURNEY

24. THE FIRST OFFERING TO THE GODS

25. THE BREAKING OPEN OF THE GATES OF HEAVEN 


\section{GLOSSARY}

The pronunciation of the vowels in Maori are:

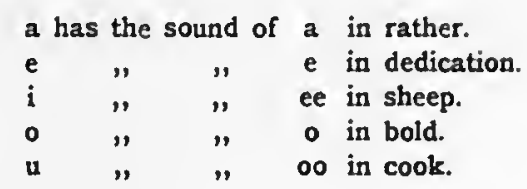

Ariki : a high chief, a leader, a master, lord.

Aroha : affection, love.

Atua: a supernatural being, a god.

Atua-toko: a small carved stick, the symbol of the god whom it represents. It was stuck in the ground whilst holding incantations to its presiding god.

Haere-mai : come here, welcome.

Haere-ra: good-bye, go, farewell.

Haere-mai-ra, me o tatou mate: come here, that I may sorrow with you.

Karakia: invocation, ceremony, prayer.

Kehua : spirit, ghost.

Kia-ora: welcome, good luck. A greeting.

Kura : red. The sacred colour of the Maori.

Mana : power, authority, prestige, influence, sanctity, luck.

Mere-pounamu: a native weapon made of a rare green stone.

Mua: an old-time Polynesian god.

Piu-piu : short mat made out of flax leaves and neatly decorated.

Po: gloom, darkness, the lower world.

Rangatira: chief, warrior, gentlemen.

Reinga: the spirit land, the home of the dead.

Taiaha: a weapon made of wood.

Tangi : funeral, dirge. Assembly to cry over the dead.

Taniwha: sea monster, water spirit.

Tapu: sacred, supernatural possession of power. Under restriction.

Taua: war party.

Tiki : first man created, a figure carved of wood, or other representation of man.

Tohunga: a priest, a possessor of supernatural powers.

Tohu-mate : omen of death.

Tupuna: ancestor.

Wairua: spirit, soul.

Whare : hut made of fern stems tied together with flax and wines, and roofed in with raupo (reeds).

Whare-puni : large, and often beautifully carved and decorated house. A meeting house.

Whare-kura: the ancient sacred building of the Maoris at Hawaiki. Those who once met there in council are now regarded as their highest gods. Whare-kura is the name of the sacred history of the Maoris.

Whaka-papa: the genealogical history of the Maori, or a tribe, or a family. 


\section{PREFACE}

WITH the drawings it began.

An expired world tried to come to life again in the fragments which some old Maori narrated. Nature all around favoured admiration only, and her loneliness was alive with longing.

Of Maori art I had never heard, and, when that art was first offered to me, I had none other to choose. At first it disgusted me. But I had to make use of my time. The evergreen nature was beautiful, and entrancing was her invitation to waste my life in her midst, as she herself was wasting hers.

To protect myself against her allurements, I began the first sketches of old carvings. Then I made more.

Sitting beside me, and looking at my work, an old Maori related the deeds of his ancestor, upon whose carved image I was at work.

And they were mighty deeds!

In the evenings later, at the camp-fire, those deeds lived again in my thoughts, and the imagination busied herself, awkwardly enough, to express new ideas with the help of new forms.

That was the beginning of the first drawing.

Out of books I could learn the old legends, but from the fragmentary narratives of my old friends they sprang into life: so the number of drawings grew-aimless, purposeless.

By that which first had disgusted me I was now greatly attracted; the forest was dreaming while I worked, the river murmured, and a strange people awoke interest and friendship.

Then, one day, came a traveller from Europe. He saw the drawings and spoke the words: "Make a book", and the magic words: "I'll get it published!" Then he went his way back to Europe again. It was four years ago.

Because these words were spoken in a far-away country, this book came to life-otherwise the destiny of those first few drawings would doubtless have been the destiny of everything else in the great nature: to wither, to fall to dust. Perhaps it would have been a pity.

As to the text of the book: 'twere better that another had written it. More serious treatises have been published by those with greater opportunities 
to hear and more art to reproduce the legends from the mouths of the old folk now dead and gone, and I owe a good deal to them, especially to Sir George Grey's Polynesian Mythology and Rev. R. Taylor's Te ika a Maui, as well as to $\mathrm{Mr}$ John White, Mr E. Schirren, and Hamilton's Maori Art. But it was to my old friends that I chiefly listened, seeking to look into the past through their eyes, to stir my imagination through their memories; yet, even though my pencil may not have done its work amiss, I have grave doubts of the work of my pen.

A part only of the legends is contained in this book: it will suffice to keep alive what I have received from my tattooed friends during the long, long days of a peculiarly strange life. The little that is new in my book does not pretend to be scientific: I have written it to help my drawings along their way.

And, after all, the book would possibly never have been completed without the friends which the drawings made in New Zealand, above all Augustus Hamilton, Director of the Colonial Museum. The encouragement and help I received from him, the benefit of his wide knowledge and love of art and of all things Maori, and his true friendship, gave confidence to my wavering hopes of representing graphically the imaginings of a people so alien to and so distant from the European mind.

At last everything was done: the parting hour came-from the new home back to the old. And now my thoughts are wandering back, often and often, to that distant time when everything was at its beginning: when the tent was pitched under the willow on the river, and from the Maori village on the other shore issued the sounds of happy life; when morning after morning the sur rose golden over the hills, and every night the river reflected the silvery stars; when the willow grew slowly yellow, and the falling leaves gilded the tent; when the smoke of the camp-fire rose blue into the skies-and the first drawing was finished.

W. DitTMER.

London : 1907. 

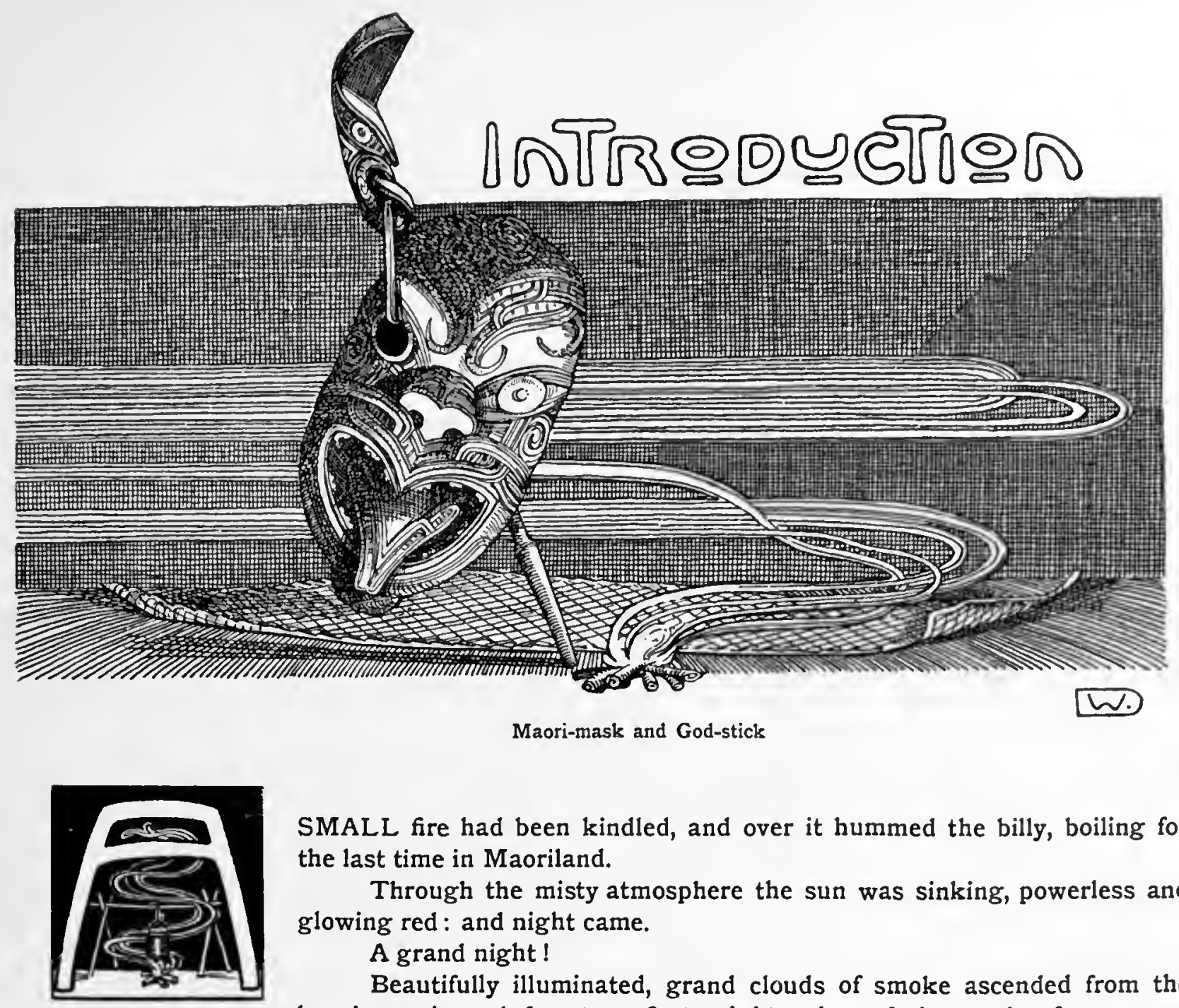

SMALL fire had been kindled, and over it hummed the billy, boiling for the last time in Maoriland.

Through the misty atmosphere the sun was sinking, powerless and glowing red: and night came.

A grand night!

Beautifully illuminated, grand clouds of smoke ascended from the burning primeval forest-a first mighty sign of the work of man, and the will of man, for the fire has to finish the work of the axe, and to consume the forest.

Stars in silvery brilliance bespatter the East; the West is all aglow with crimson, gold, and creamy white; but to-morrow work and care will follow the great destruction, for endless is the beauty of this ever green country, but its liberty and its fruitfulness are labour.

He who wishes for liberty must till the soil, and the fruit of liberty shall be art, for art is not an image, but a fruit.

A strange fruit is once gathered by the Maori children of Nature, a fruit grown out of the darknesses of the ocean-encircled forests-an art, hopeless and sad. A fruit without seed.

Was not Darkness the mother of All? Does not the everlasting ocean encircle all? And in the end must not Darkness again swallow all? This art followed the ways of untiring Nature: unseeming tools, unmeasured time, and endless labour, shaped to perfection the hardest stone into the "mere pounamu," the beautifully formed and polished greenstone-weapon - the giant of the forest into the wonderful war-canoe.

Sharp-edged stones and shells have to shape the tree into the centre-post of the house, into the mighty figure of the god and ancestor; and such labour stands in grim need of incantations to the atuas (gods) who dwell in the darknesses of the Lower World and who dwell in the spaces of light above the earth, that they may strengthen and enliven the unseeming tools with their god-power.

The sages and dreamers of many generations had spent their lives bending over the smoke of their little fires, and forming into wisdom what their eyes perceived of the wonders 


\section{ANCIENT LEGENDS OF THE MAORIS}

of the world; and their wisdom has resulted in incantations and Karakias * powerful enough to overcome the gods.

These incantations and Karakias are tapu, that is, sacred. The possessor of them is a Tohunga; a Tohunga is sacred. The tapu of the Tohunga is descended from the gods, and so is his wisdom. The gods are all descended from the Great Mother Darkness, the goddess Hine-nui-te-po; and they are the ancestors of mankind, which with every generation moves farther and farther away from the gods.

Once a great inspiration must have fallen upon the Maori world; but since then generation followed generation, framing incantations, speculating, shaping-never renewing, never widening, this inspiration, but working out form and expression to perfection.

The life of man became like the life of ever-renewing Nature, producing and again destroying, giving birth, and again killing, to enable life to be sustained: the souls of man grew into the rigid wisdom of incantations; the food of man became man.

He who wishes for art must till the soil, but he who tills the soil must have faith; for art, though a fruit of Nature, is a child of god.

With the rising Sun came the old friend, and placed fresh wood on the camp-fire, a work of love; for he is a Rangatira-Tohunga (chief priest) of great mana in his tribe, and his tapu forbids menial labour. With Sorrow in his face, he sat down, quietly laying a parting present at our feet.

On the water of the river sways the reflected canoe loaded for the journey, and the sun plays among the leaves of the trees, the children of the God Tane-Mahuta.

"Take with you the wisdom of the old people, my wanderer, the wisdom which will be soon forgotten among my children, who follow now the ways of the pakeha (the new friends) who came to us bringing the truth of their God; and we are now all children of the great Queen over the seas, who promised to be our mother. Go in peace, my friend!"

Deeply thinking, he looked in the glowing embers. Each followed his own thoughts.

Far away at Hawaiki was the world created, and there is the home of the Maoris. It is the birthplace of their race; it was the dwelling-place of their ancestors, who are gods now, and live in the heavens; it is their Spirit Land.

Their ancestors built the whare-kura, the sacred Temple, at Hawaiki, and it stood facing the East, at the place of Mua. In the whare-kura assembled the highest chiefs and the Tohungas of all the tribes to communicate with the spirits of the gods, and to repeat and rehearse the names and heroic deeds of their ancestors, that they might take deep root in the hearts of the living, and that they might never forget their descent from the most ancient gods, who dwelled in the Darkness, the Nothing, and the Beginning of All Things! They assembled to acquire and repeat the sacred wisdom of the incantations, the ceremonies, and the traditions, from Te-Kore, the Nothing to Te-Po, the Lower World, to Te-Ao, the Light, to Rangi-nui, the Great Heaven, and to Papa-nui, the Great Earth; the incantations and Karakias to the Gods of War and of Witchcraft, and the food; and all those to the multitude of spirits who govern, help, or hinder, the living.

From Hawaiki the heroes and their tribes wandered over the seas, and the Tohungas took with them the wisdom of the whare-kura, guarding it sacredly, and repeating it only to the ears of their descendants or to those of high rank and ambition; and nothing of the sacred knowledge was lost from the days of Te-Kore to the present time; but now it is dying with the last Tohungas.

Little only is known of the sacred wisdom of the Maoris. The dread of the old gods is still living in the hearts of the Maoris, but the last hour has come for them as they now bend their tattoed heads over the fire and murmur regretfully of the great Past.

* Religious rites and ceremonies. 


\section{INTRODUCTION}

Thoughtfully looked the old friend at me, and I spoke :

"Farewell, friend. Wide you opened your heart, and far away will I take your love with me; far away into the Great Distance, to my Hawaiki; and always will I think of the Tohunga of the Maoris, the Rangatira, my friend.

Small was my little knowledge, and bad were my tools to form it into pictures; and I was in need of the incantations to the atuas, who have the art in their keeping: the gods who have the happiness and hope, the comprehension and confidence in their keeping. In the whare-puni of my friends, the Maoris, I found these atuas, and more, a friendship which made the loneliness fly away like a dark feather before the morning wind. Farewell!"

"Haere, e tama taku-farewell, my son. This song out of ancient time I give you, for your eyes can look back into the past; but my eyes are dim like my wisdom.

Look often at the sign which I have put to it, that you may remember me. Farewell, Kia-ora.-

Kia-ora.'

\section{HIS SONG}

O, thou sun, advancing high,

Beaming red, and blazing forth!

$O$, thou moon, now moving onward,

Sending here thy lesser beams!

The host of heaven-

The gods now there-

Can see and gaze on you.

Come forth thou hidden

Cause of blindness in mine eyes,

Thou blood-red blight

Of waters sweeping o'er my sight.

Come forth, that I

May live, and see again,

And gaze as I was wont.

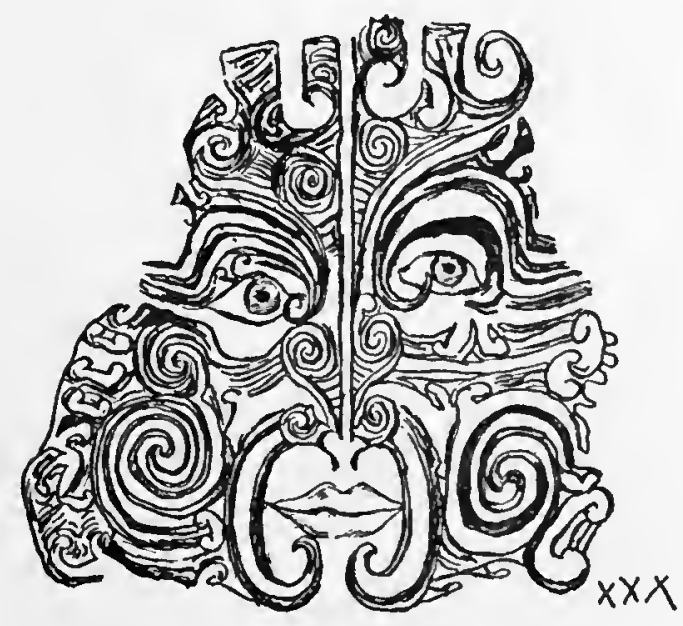


TIKI-THE ANCESTOR OF MANKIND

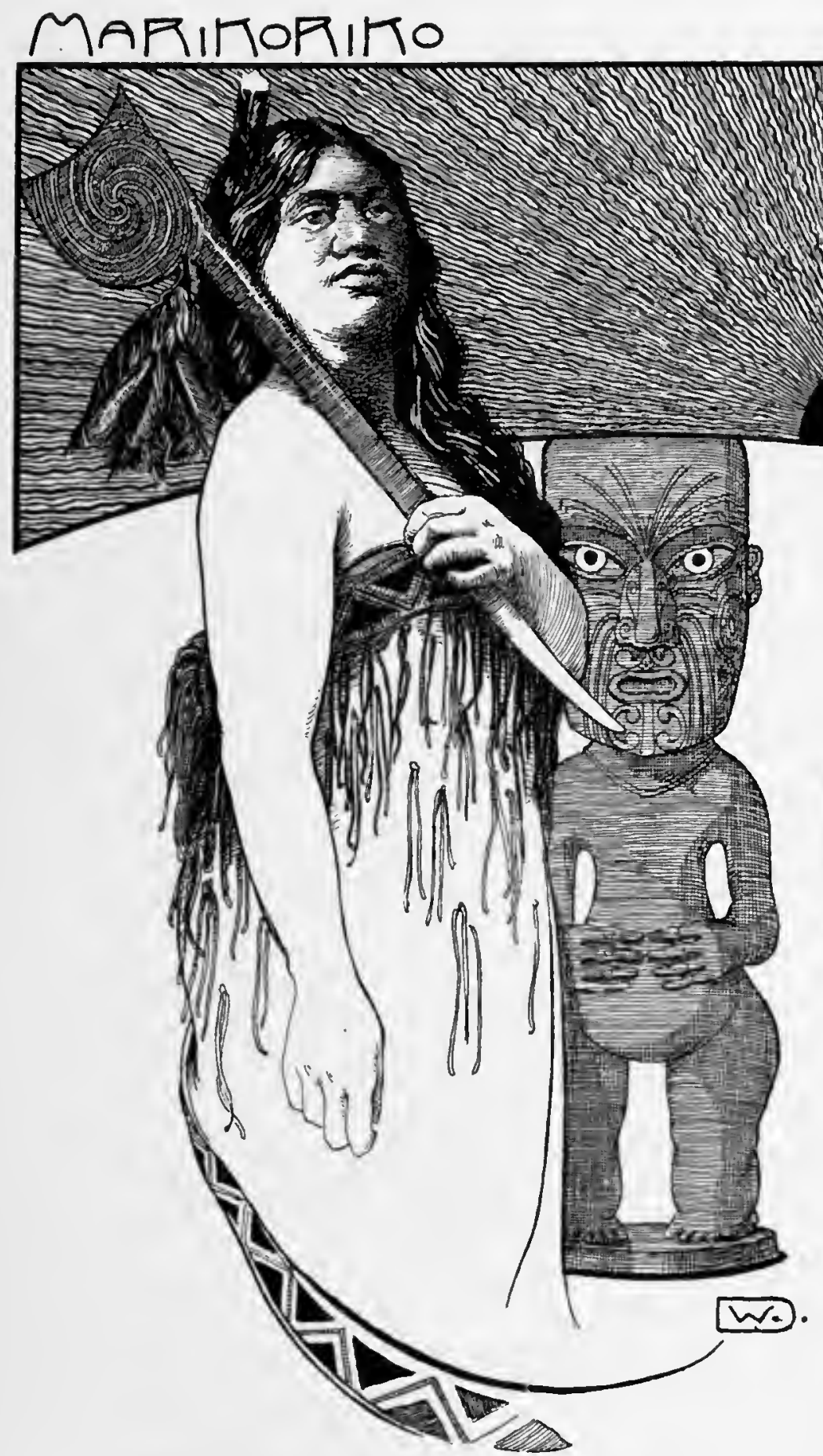

Marikoriko, the first woman, and Tiki, her Creator.

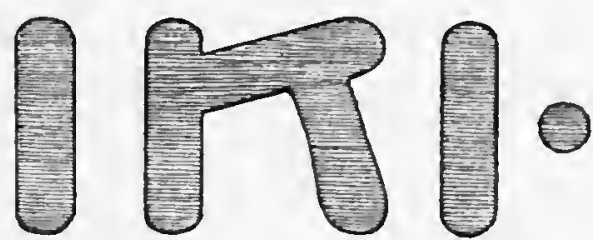

Hupene, the old Tohunga, squats muttering on the floor beside his carved ancestor Tiki.

Tiki is a god who in the dim long ago helped to build the world, and whose carved image is now supporting the middle pillar of the house. His eyes of pawa-shell, which once commanded in the ten Heavens and were full of fire and wisdom, glisten out of the silent twilight; they stare far, far into the darkness, which Hine-nui-te-po is slowly spreading over the world, Hine-nui-te-po, the Great Mother of Night, who at one time was young and beautiful, and gave life to Nature.

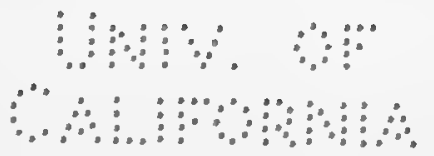




\section{ANCIENT LEGENDS OF THE MAORIS}

"Haere-mai, e te manuhire, Haere-mai" ("Welcome, stranger, welcome"), so speaks the old Tohunga; then, drawing his flax mat around him, he mutters: "Haere-mai", and, after a long silence again, as if murmuring to himself, "Haere-mai"-but soon his eyes follow those of his ancestor again, gazing into the silence of the slowly descending night, the ancient goddess Hine-nui-te-po, the Great Mother of Rest. Wisdom dwells with the aged, and their muttering is the sign that their wisdom is ripe. Flying from the mouth of the old it becomes mother now and wife to the listening ear.

"Listen, my guest:

When man dies, he returns no more to the place which once knew him. Unlike the Daughter of Heaven, Te marama, the moon, which ever ascends to new life from the Spring of Living Water, man must die: he is devoured by Hine-nui-te-po, the Great Mother of Nature, the first among the gods; and man is her food.

Ha, hear now the story of Tiki, our Father, the Father of man!

When Rangi-nui, the great Heaven, and Papa-tu-a-nuku, the far-stretching earth, were separated from each other, then, my listener, the light shone over Papa-tu-a-nuku, the mother of Tiki, and he was the first man.

Ah, great was his longing for the power to spread himself out over Papa: father of mankind he wanted to be! Far, and far, and far he wandered over Hawaiki, searching and asking, and again and again he wandered forth over all Hawaiki, his heart full of longing.

Ah, my listener, full of longing was his heart.

At last he came to the river at Hawaiki known by the name of Wai-matu-hirangi, and from the depth of his desire he cried aloud: 'Oh, daughter of Hawaiki, child of the murmuring water, tell me how I may become the father of mankind. Tell me where may I obtain the power and from whom?'

And the river Wai-matu-hirangi answered him and said: ' $\mathrm{Ha}$, Tiki, son of Heaven and Earth, go and search for the incantations and the powerful Karakias to the gods who have the desires of man in their keeping, and when you have obtained them return to me here, for it is here that the child of man shall be born : out of the murmuring waters at Hawaiki. Go, and search!'

$O$, listen to Tiki, our father, the father of man.

$\mathrm{Ha}$ !-see how he set out on his search. First he journeyed to the gods of Te Po, the Lower World, and then he made his toilsome way through the ten heavens, searching for the sacred incantations and the Karakias, the object of his mighty quest, and at last, high, high in the uppermost heaven, he found them-ah, my listener!

Joy made his journey light and the distance easy, and it was with a gladsome heart that he stood once more by the river in Hawaiki and cried aloud:

'Oh, Daughter of the Many Faces, I bring with me the Karakias to the powerful gods, the great incantations which will give power and ecstasy to Tiki. See, I bring the incantations for which I went in search.'

Then he knelt down, and, as the gods had commanded him, mixed the sacred red colour with the soft sands of the shore, and formed a figure like unto himself, as he saw his own image reflected in the water. Full of joy, he shaped the body and the limbs, the head and the eyes; and then he commenced to chant the sacred incantation, the first lines of which are as follows:

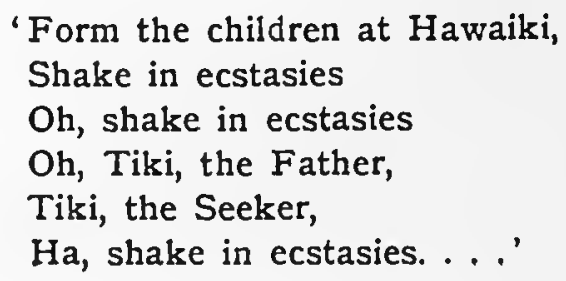




\section{TIKI-THE ANCESTOR OF MANKIND}

And so, with the help of the Shimmering Heat and the Echo, the power of multiplying, he gave life to the first woman.

Marikoriko, or Twilight, was the first woman!

Marikoriko, my listener, was not a child of the gods; she was created out of the sands of the shore and the sacred Red; she takes her descent from the Shimmering Heat and from the Echo, and she became the first wife of Tiki, our father.

Many children were born to Tiki and Marikoriko his uife. Their daughter was Hine-kau-ata-ata, the Floating Shadow. And the children of Hine-kau-ata-ata began their lives as clouds, wandering across the sky. They were light, and flew far away till lost to sight in the distance, or they were heavy and did not move and brooded overhead in rain. Then it was that Papa-tu-a-nuku, the Earth, lay under the spell of the first awakening day.

Among the many children of Tiki and Marikoriko were the sons the Power of Speech and the Power of Growth, who took their sisters to wife, and Te-a-io-whaka-tangata, 'He who became man', was born, and he was the father of many children-the Maori children of the world.

This is the wisdom of Tiki, our father, and Marikoriko his wife, the parents of man who peoples the earth. The wisdom of Tiki, our father.

Welcome my guest from the far distance, welcome!

You give pleasure to my eyes, and in your ears has sounded the wisdom of Tiki.Welcome, friends of my guest.

Welcome all!
Welcome!"

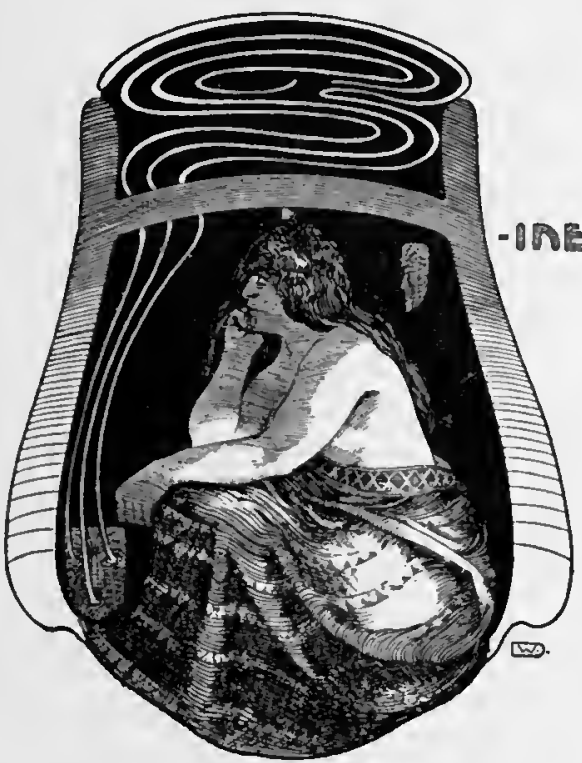

has swallowed the world again and Rangi looks down upon Papa out of his Eye of Night, the moon, and is slowly unfolding his beautiful garment, which is adorned with the stars-the eyes 'of the braves who fell in battle.

Fiery looks Maru down upon the women who kindle the cooking-fire; Maru was the god of war in Hawaiki, but he was an evil god, full of anger and wrath, and from him are descended illness and murder. He had many enemies, and at last they killed him, and devoured him; but his spirit flew up to Rangi, there to become the fiery and flashing star.

Rauriki, the oldest among the women who kindle the cooking-fire, murmurs, for she is old, but she is a woman and murmurs no wisdom; she murmurs incantaticns to the fire that it might listen to Maui, who once brought the fire into the world-to be bright and warm and to cook the food for the hungry and for the guest.

Silent and peaceful is the night. The Great Mother of Nature swallows silently a few old songs and the low-toned voices that sound out of the huts and the whare-puni.

Ngawai, Rauriki's granddaughter now takes the embers to the whare-puni, and puts them to the feet of Tiki, to warm and light the house, and outside Night is working her grand and lonely wonders, while the old men, squatting around the fire and staring into the flames, narrate of the terrors of Hine-nui-te-po.

Musing and wondering thoughts light up the glow of the fire in the faces, fire flashes out of the pawa-shell eyes of the old ancestor, and patches of light flicker over the group that surrounds 


\section{ANCIENT LEGENDS OF THE MAORIS}

the fire, now lighting up the artistic lines of the tattoo in the faces, now again the phantastic carvings on the walls, or suddenly brightening a painted ornament, and covering the rest with impenetrable blackness.

Every line the light reveals, every colour it displays, gives knowledge: each carved image is a part of the history of the people. It is the family history of the group around the fire, their history painted by the god of the fire upon the black garment of night-and with the fire it will die, swallowed by Hine-nui-te-po. And so in the end all will die, the words, and the speaker, and the listener: they all will at last be devoured by Hine-nui-te-po, who has brought forth Rangi and Papa, who has brought forth Tiki, who made Marikoriko his wife.

Out of the womb of Hine-nui-te-po came the word, and to her all must go back - as the fire to the ashes.

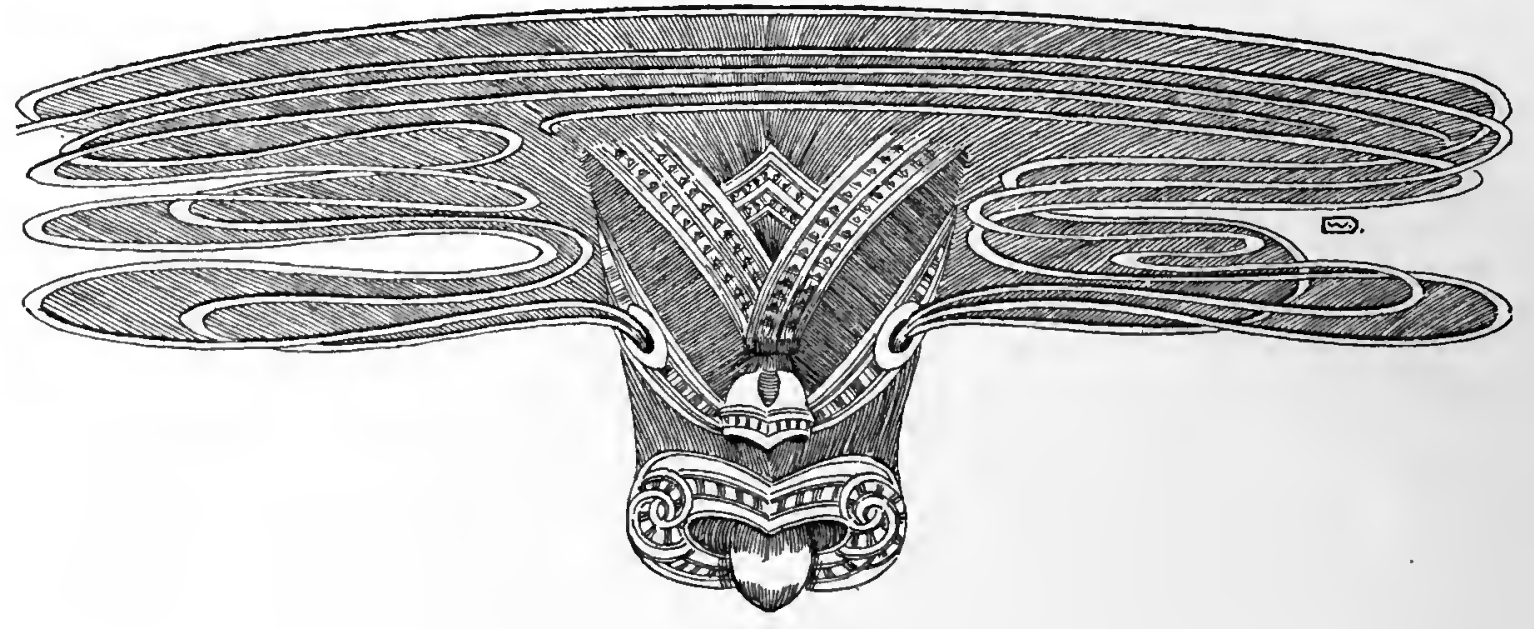


THE CREATION OF HAWAIKI

"Here friend"-so speaks Ngawai-"sit beside the old man of my people, and listen to the song of the gods, which is living in the mouth of the blind Matapo, and know that Truth is dwelling upon his lips. Listen to his words!"
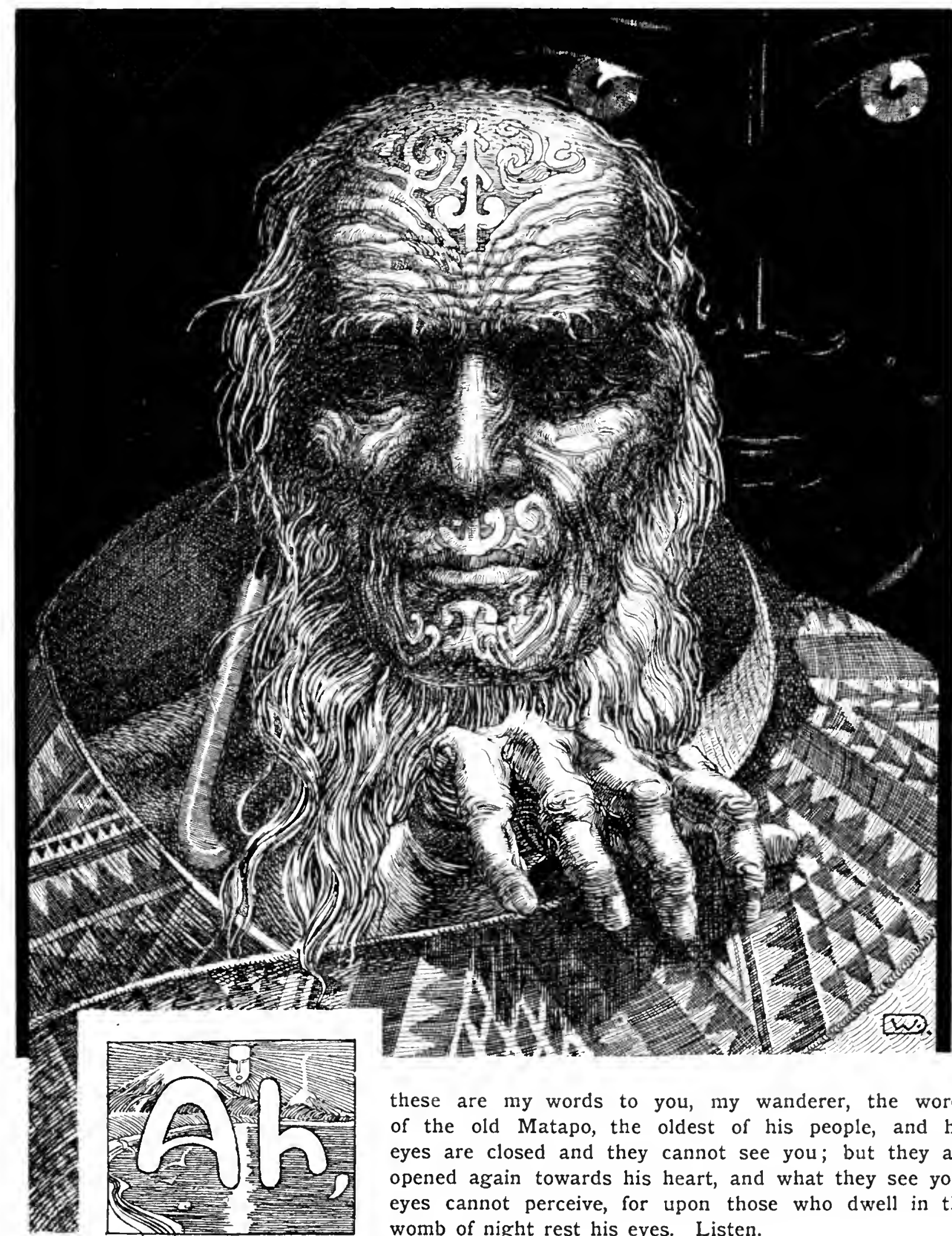

these are my words to you, my wanderer, the words of the old Matapo, the oldest of his people, and his eyes are closed and they cannot see you; but they are opened again towards his heart, and what they see your eyes cannot perceive, for upon those who dwell in the womb of night rest his eyes. Listen. 


\section{ANCIENT LEGENDS OF THE MAORIS}

The beginning was J-o, the great atua, the god-power, and the world was filled by Te-po-nui, the Great Darkness - ah! - Te-po-nui filled all the space, from the first space to the hundredth, to the thousandth space.

$\mathrm{Ha}$, my listener, then was it that the Atua commenced his great song of creation, and out of the Darkness sprang forth Life!

And out of the Darkness sprang forth Hine-nui-te-po!

And out of the Darkness sprang forth Te Ao, the Light!

Ha, my listener, Te-Ao-ha !-Te-Ao gave birth to Rangi! Rangi-nui, the great Heaven.

And again sang the atua his great song of creation, and out of Te-po-nui sprang forth Tangaroa, the God of the Oceans!

And out of Te-po-nui sprang forth Papa-tu-a-nuku, the far-stretching Earth.-

$\mathrm{Ha}$, the Earth was created! The Earth, and Rangi, the Heaven.

Ah, Rangi-nui, the great Heaven!

Rangi took Hine-nui-te-po for his wife, and their son was Ha-nui-o-rangi, the Great Breath of Heaven. And Ha-nui-o-rangi commenced his great movement, and forth sprang Tawhiri-matea, the father of the winds. And again Ha-nui-o-rangi commenced his great movement, and Te-ata-tuhi sprang forth, the First Glimmer of Light.

Te-ata-tuhi was a woman, and Rangi took her to wife. Her daughter was Te marama, the Moon, and Rangi spoke full of joy:

"O, woman, Te-ata-tuhi, look upon the beauty of Rangi's daughter; ha, she is his daughter for which he was longing"; and he made her his eye, his Eye of Night.

Lightening his path, he went in search of his son. He found the woman Te wera-wera, the heat, and his heart went out to her, so that he took her to wife, and Te-Ra was born, Te-Ra, the Sun! Then cried Rangi full of joy: " $O$, woman, Wera-wera, look upon the beauty of Rangi's son-ha, he is his great son for which he was longing"; and he made him his other eye, his Eye of the Day.

Ha, my listener, great now was Rangi's power, Rangi, the Creator! His eyes beheld with admiration Papa-tu-a-nuku, the far-stretching earth, shine forth out of the Darkness, and she was of great beauty.

Ah, she was of great beauty, and Rangi made her his wife that together they might create Hawaiki, and their first son was Rehua. With him were born the rays of light, and he flew high up into the highest heaven, which he made his dwelling-place. He became the god of the highest mountain-peak and of the Locks of Heaven, the Sun-rays, when he stands highest on the heaven; and he became the ancestor and the ariki (Lord) over all the spirits and gods in the heavens.

Then Tane was born, and he was the god-power of the masculine sex, and the father of trees and birds. He and his brothers took Papa-tu-a-nuku for their dwelling-place.

The next son of Rangi and Papa - ha, listen my wanderer-was Tiki, our Father, who created Marikoriko, his wife, and became the father of man! Ah!-

Rangi and Papa!-Ah! Rangi looked upon the Far-stretching Earth out of his Eye of Night and admired her beauty; and he looked upon her out of his Eye of Day and his heart was full of joy, so that he spoke:

"O, woman, Papa, nevermore will I be parted from you; together we will be the world; the parents, Rangi and Papa!"

Then their fourth son was born, Rongo: he was the God-power of Good, and the atua of the Tapu and the sacred incantations; he was the creator of the food for man and the wisdom of cooking and the incantations over the food.

Their fifth son was Tu, the atua of all evil and the god of war.-Ah! -

As you have opened your ears to the song of the old man, who is your friend, my listener, so open now your eyes, that they may show you how night presses upon earth, and darkness has swallowed all, for, know, such was the night and the darkness which reigned between heaven and earth, everlasting, from the first time to the hundredth time, to the thousandth time-Ah, 
THE CREATION OF HAWAIKI

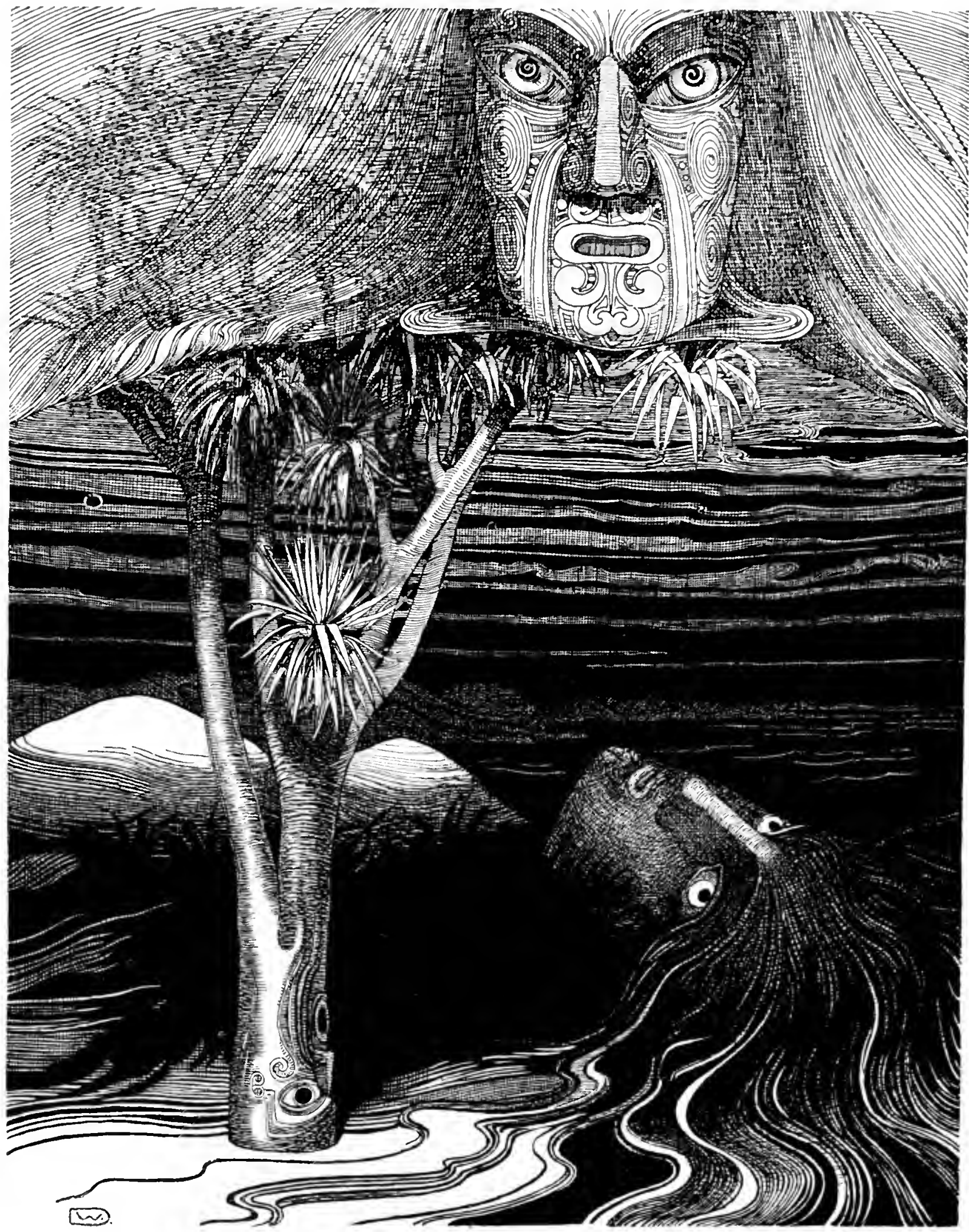




\section{THE CREATION OF HAWAIKI}

know, my friend, when the world was still dwelling in Te-po-nui then was it Tangaroa, the God of the Oceans, who had taken Papa-tu-a-nuku to wife, and their sons were Tinirau, The Many Hundreds, who founded the Family of the waves which encircle the earth. When Tangaroa had perceived Te-ata-tuhi, the First Glimmer of Light, he wandered forth to find the Gate of Day. Ah, far he wandered, far into the last darknesses, and farther and farther, to the very end of Te-po-nui; but when he came back, then, ha, my listener, then did he find Rangi the ariki over Papa-tu-a-nuku.

Ah, the Heaven was the ariki over the earth!

Full of rage, Tangaroa fell upon Rangi, and wounded him terribly, so that he could not stand and fell upon Papa, and never could lift himself any more, and no space and no light could come to his sons from this time. Ah, the sons, whose dwelling-place was upon the earth, they had to live in darkness and night-ah!-ha!; but the sons!, ha, but the sons! Their hearts filled with the longing for the light, that happiness might grow again; and their hearts filled with the longing for space, that the power, living in them, might be born.

$\mathrm{Ha}$, the longing in the hearts of the children of Rangi and Papa became the mother of the great incantations which gave them the power to create space again between heaven and earth so that the light could come to them like a wife to all.

And the voice of $\mathrm{Tu}$ spoke out of the darkness:

"Listen, all my brothers, together let us overcome Rangi, and let us kill him, for he gives us no room and covers us with blackness! Let us kill Rangi!"

But, my listener, the voice of Tane spoke out of the darkness, and this is what she said :

"Listen, all my brothers, how can we kill Rangi? Is he not our Father? Listen, all my brothers, and this is Tane's word: No, do not let us kill him, but let us search for the incantation to compel our brother Rehua and the host of spirits who dwell outside to help us in our great work, that we may lift our Father upon the highest mountains. Let us hold the Karakia that we may become sacred for our work to lift Rangi from Papa. Let Rangi be far from us, and let us dwell with Papa, our mother."

' $\mathrm{Ha}$, these were the words of Tane!-and all the voices out of the darkness spoke their consent, and all the voices together chanted the great incantations to Rehua and the host of gods and spirits calling upon them to come to their aid. Then, my listener, they commenced the sacred Karakia which is held to become strong and unconquerable, all together they chanted this powerful song:

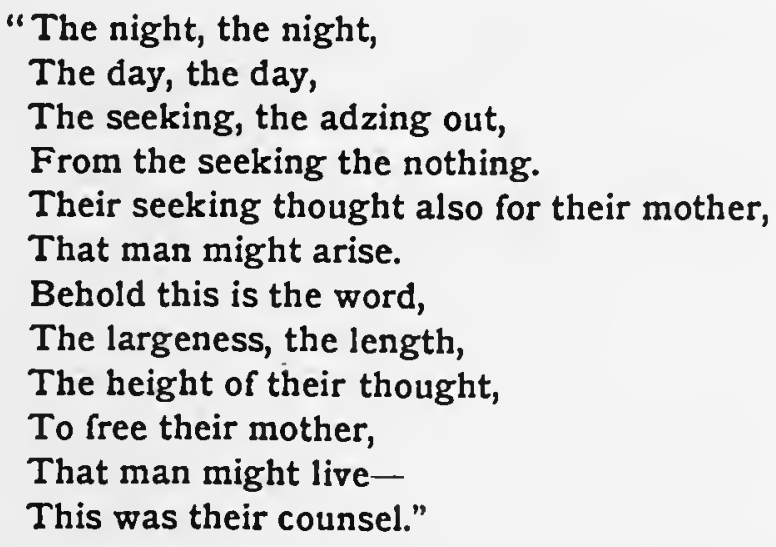

$\mathrm{Ha}$, Tu now took the sharp-edged stone, and cut the sinews and bands with which Rangi pressed the earth to his breast, and frightful were the cries of the heaven-ah! Then, calling on Rehua, the strength of the sons grew, and grew, and grew-ah!, my listener, all their strength -but where was the power that could separate the parents? ah-ah! Rangi the powerful could not be separated from Papa; Tu could not find strength enough, and where was the strength of Rongo? And the strength of Tiki? Then came Tane! 


\section{ANCIENT LEGENDS OF THE MAORIS}

\section{Ah, Tane!}

Open the eyes of your mind-as you have opened your ears and your eyes. Open the eyes of your mind that they may perceive how Tane separated Heaven and Earth. See how he presses the head of his god-power on the breasts of Papa-See his hair grow and take root-ah,See how his body and his limbs begin to stretch:-high, high above, his feet grow into branches and baughts-See how his power grows-oh, how he grows all-powerful into the heaven-Ah, see how his power overcomes the strength of Rangi!

$-\mathrm{Ha}$, he lifts him!

He lifts the Heaven!

Higher!

Higher - ! Ha, the heaven is high!

Ah, Heaven and earth are separated-!

Hawaiki is born!

Oh, Tane-!

Ah, my listener, Rangi and Papa are separated!

From high above Rangi sent down many words of farewell, so that they sounded all over the Far-stretching Earth, and many were his songs of love to Papa. Ah, his tears still fall upon Papa-they are the dew of the mornings. And Papa sang words of farewell, and her sighs flew up to Rangi as white cloud-messengers of love. Ah-.

Great was the love of the parents, my listener-

Great was the strength of the children!-

Your ear has received the wisdom of the creation of Hawaiki, the home of my people, the Maoris.

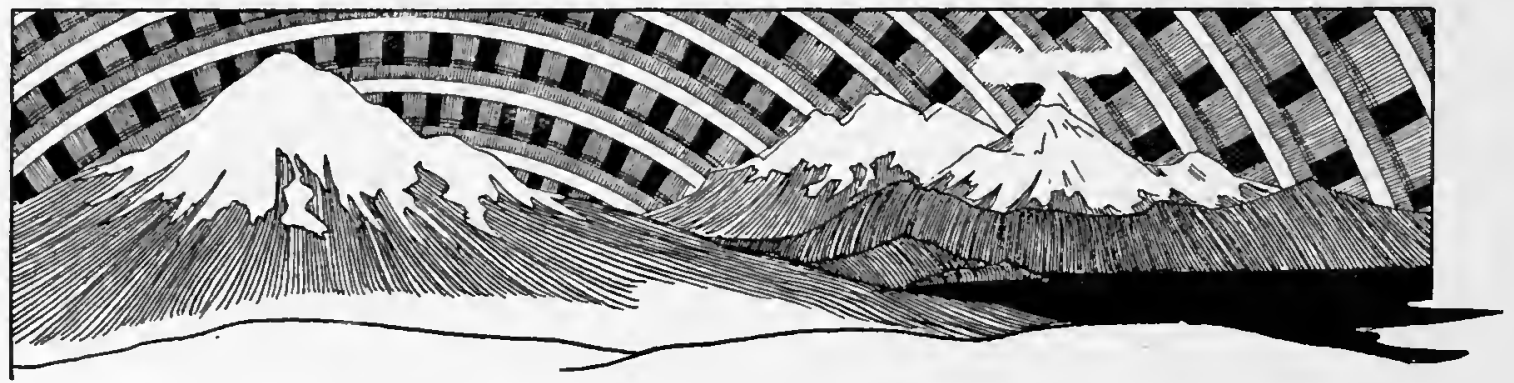




\section{THE POI-DANCE}

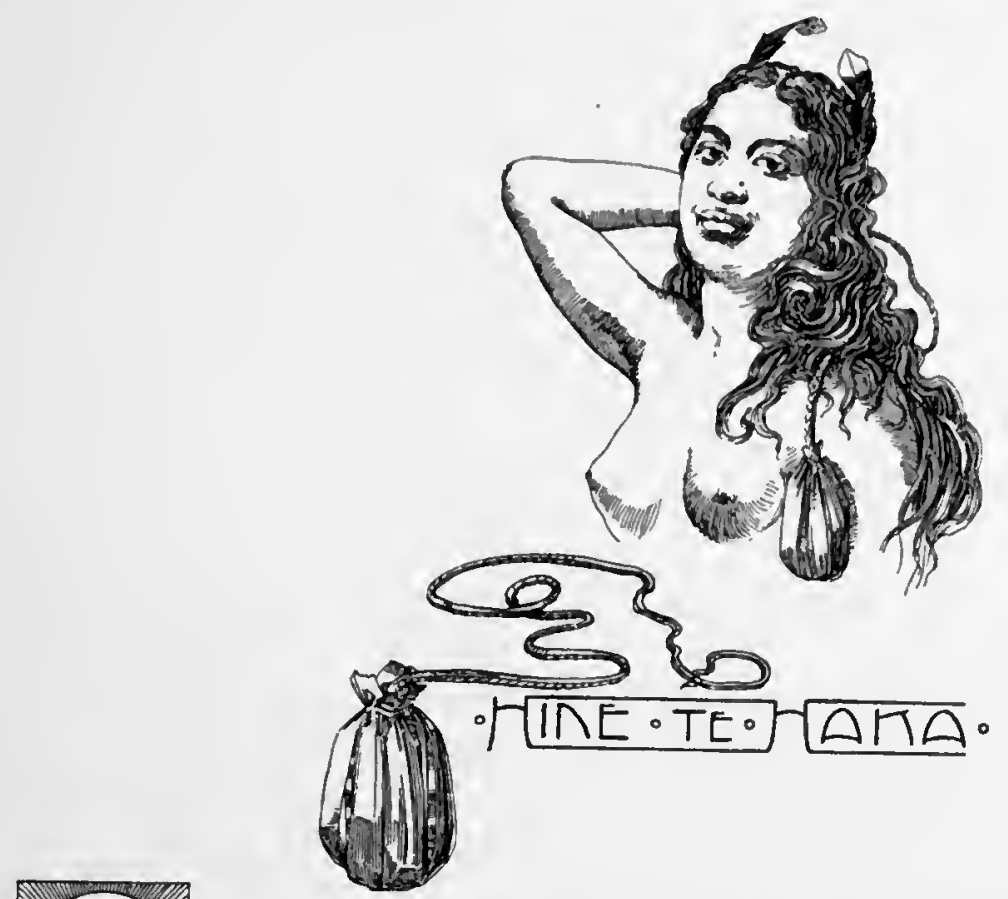

UT of the semi-darkness of the wharepuni a shrill voice is ringing, and soon is accompanied by other voices and by clapping of hands, beating time for a poi-dance.

Discordantly the first voice pierces the bustle, and laughter there is, and moving and shifting, to make room for the dancers, for the girls and the young women.

Graceful figures dressed in piu-pius come forward, coyly and laughing, with whirling of pois*, taking up their positions, and all is clamour of getting ready for an amusement, highly enjoyed by spectators and dancers.

Like clock-work hands are clapping all the while; the shrill voice is dominating the chorus, and all the old women and the men, squatting around in a circle, settle down to an inexhaustible song.

In two rows stand the dancers, light in their eyes, grace and laughter in every movement. Ngawai is leader, Hine-te-haka, "the maiden of dance".

A sharp cry falls from her lips, and is answered by the dull thud of the pois, caught in the open left hand after being whirled around the head.

Four times whirl the pois through the air, and four times, perfect in time, follows the dull thud, while the song is going on and the clapping of hands. Now another sharp cry comes from Ngawai's lips and rhythmically the bodies of the dancers begin to move: slowly, into graceful positions, while the dried flax-strings, which form the piu-pius, are clapping against the naked limbs, and the play of the pois commences. An uninterrupted whirling around the heads, around the shoulders, in the out-stretched arms, now through the air, before the breasts or behind the backs, beaten again and again with the dull thud upon hand, head, shoulder, or floor under the rhythmical movements of the bodies, the soft stamping of the bare feet, the slapping of the piu-pius and the clapping of hands, ending again in the four times repeated thud in the open hands.

Enjoyment is in the eyes of the spectators, and happiness seems to enliven the monotonous song; the clapping of hands sounds joyful, and the bosoms heave quicker.

Like wonderful birds flutter and whirl the pois around the heads, musical is the rolling

- A poi is a small egg-shaped object made of raupo (reed) and dried, hanging on a little flax-string. 


\section{ANCIENT LEGENDS OF THE MAORIS}

movement of the arms, the bendings and turnings of the figures, the crashing of the dry flax-strings of the piu-pius against the bodies: precise are the movements, the thuds of the pois sound as if cast by a single arm; the rolling, lifting, and stretching, of the arms, the movements of the heads and shoulders, hips and legs, as if from a single body.

Quicker grows the clapping of hands, louder shrieks Ngawai, fiercer become her movements. She stands opposite the dancers: she leads, and all follow her movements.

A short cry, a hiss, a head thrown back, a wild yell, call forth ever new, ever graceful, ever circling, combinations, bendings, and turnings. Whirling, circling, slapping, stamping, becomes the dance; rolling arms, back-bending heads, moving hips, and heaving breastsfiercer yet grow Ngawai's shrieks, swifter her movements, undistinguishable the mass of the ever-whirling pois. Full of laughter and grace is every movement of the vast living body of weaving, rolling, and bending, figures; joy is in every face, light in the eyes of all. Like black waves floats the hair around the heads, the bosoms heave quicker and quicker, and the breathing mingles with the song of the spectators-: a vast, beautiful, ever-moving body is the whole, with its ever-circling pois.

A loud and joyful cry-and all is over, abrupt, with one thud.

In the sudden silence the dancers flutter about, and settle on the ground like a swarm of birds; loud is the applause, and Ngawai, with laughing eyes and quick-heaving bosom, stands before us, and drops the little poi at our feet.

\section{TRADITION}
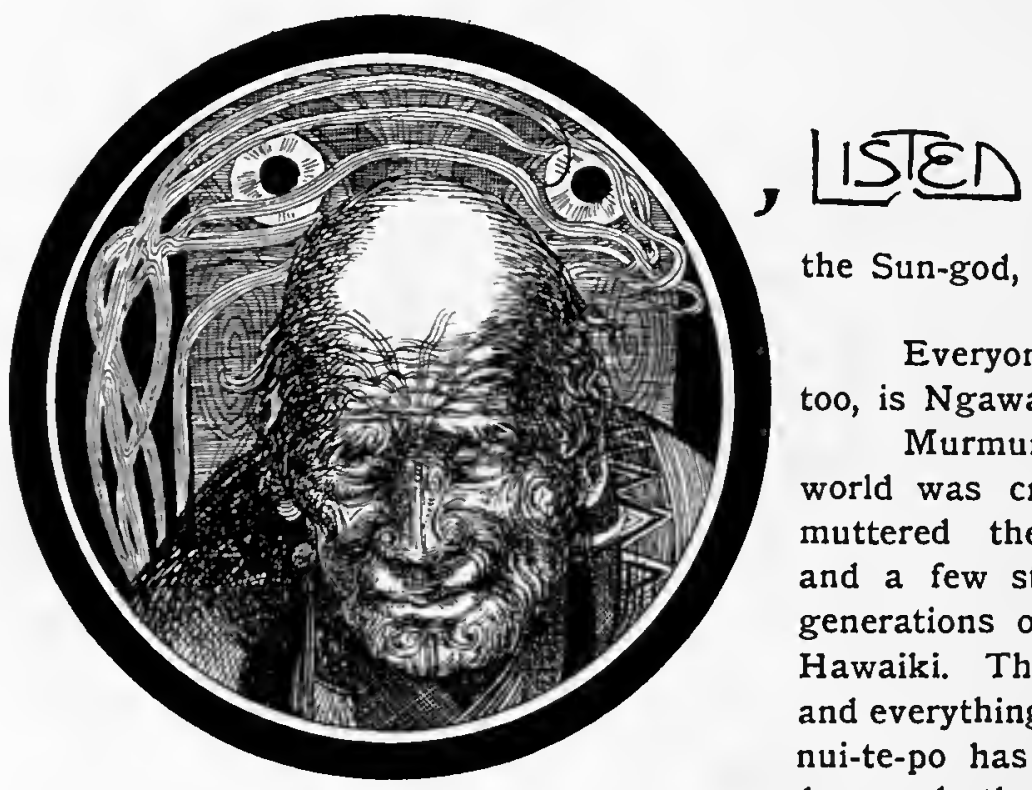

who will deny the truth of the old gods? Who can deny the truth of the Sun-god, Maui?

Everyone is asleep in the whare-puni, asleep, too, is Ngawai.

Murmuringly had Matapo recited how the world was created; deep into the night had he muttered the wisdom known only to himself and a few still living Tohungas, the wisdom of generations of gods and ancestors and heroes of Hawaiki. Then he, too, had dropped off to sleep, and everything is loneliness and blackness, for Hinenui-te-po has finished her great repast, and has devoured the world once more. Only the fire splutters now and again with flickering life, and answeringly a dim sparkle springs forth from the eyes of the old ancestor.

Once, ha, once the gods were living at Hawaiki; they were the ancestors of mankind; they are human beings in the faith of the Maori people, heroes, who were the authors of superhuman deeds.

How is it possible for Maui to fish this great and beautiful land out of the ocean? Maui, the hero? But, is not Maui the Sun himself? And is it not the Sun who destroys the darkness of night so that the eyes of man can see the land-: Te-ika-a-Maui, or Maui's fish-swimming on the endless ocean?-

Ah, in the dark nights, whilst bending over the fire, was it in the hearts of the sages and dreamers of generations where these heroes were born; unshakable grew the faith in them, and with the growth of generations upon generations it became the Truth.-And is it not Truth? 


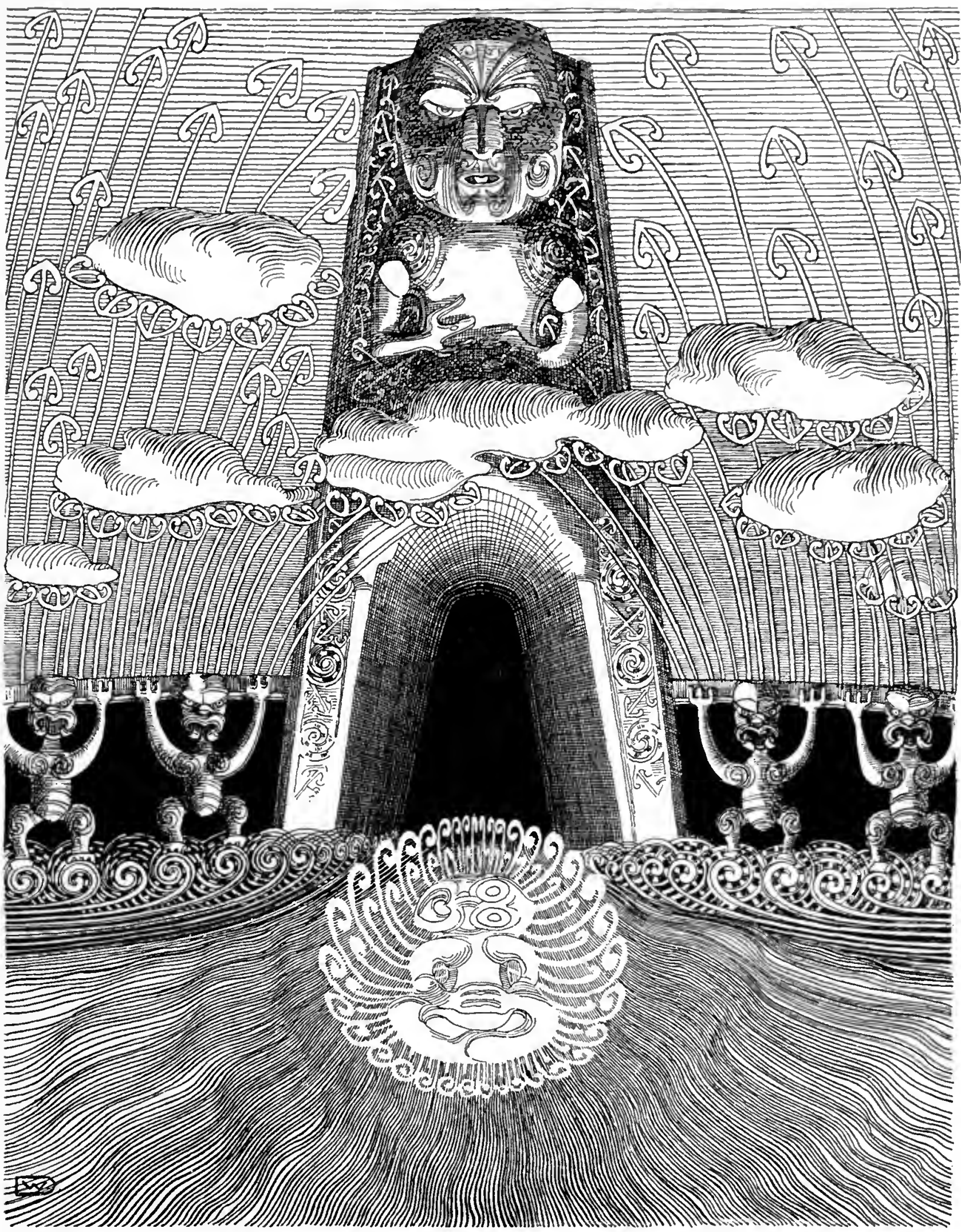

The tirth of Maui at Mahiku-rangi 



\section{TRADITION}

Is not yonder, with the dawn of the morning, the god commencing his great daily work again? Is he not preparing to lift out of the ocean of darkness this great and beautiful land again, his fish, Te-ika-a-Maui?

O, who will deny the truth of the old gods?

Who can deny the truth of the Sun-god, Maui?

Te Ra, the Sun, is the son of Rangi, but Maui is the Sun-god of human creation; he is the binding link; through him alone is it possible for man to understand the wonder of the golden Sun.

Hine-nui-te-po, the goddess, once devoured Maui, as the Darkness nightly devours the Sun, and now keeps enclosed the world. But even now the Sun is wandering through the caves of the lower worlds - Te Po-to receive new strength in its fires, and Hine-nui-te-po is lasting upon the earth, and the hearts of the Maori-people are filled with fear and horror whilst the Sun is still hidden by the east and Maui, the great hero, is not yet born with him at Mahiku-Rangi.

The last sparkle of the fire has died away and the pawa-shell eyes of the old ancestor are swallowed by the Darkness.

O, who will deny the truth of the old gods?

Who can deny the truth of the Sun-god,

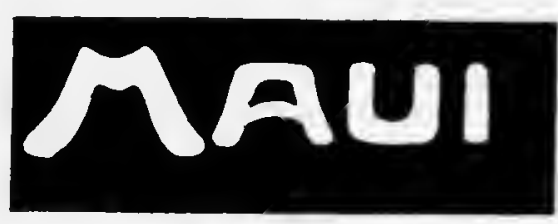


THE CREATION OF THE STARS
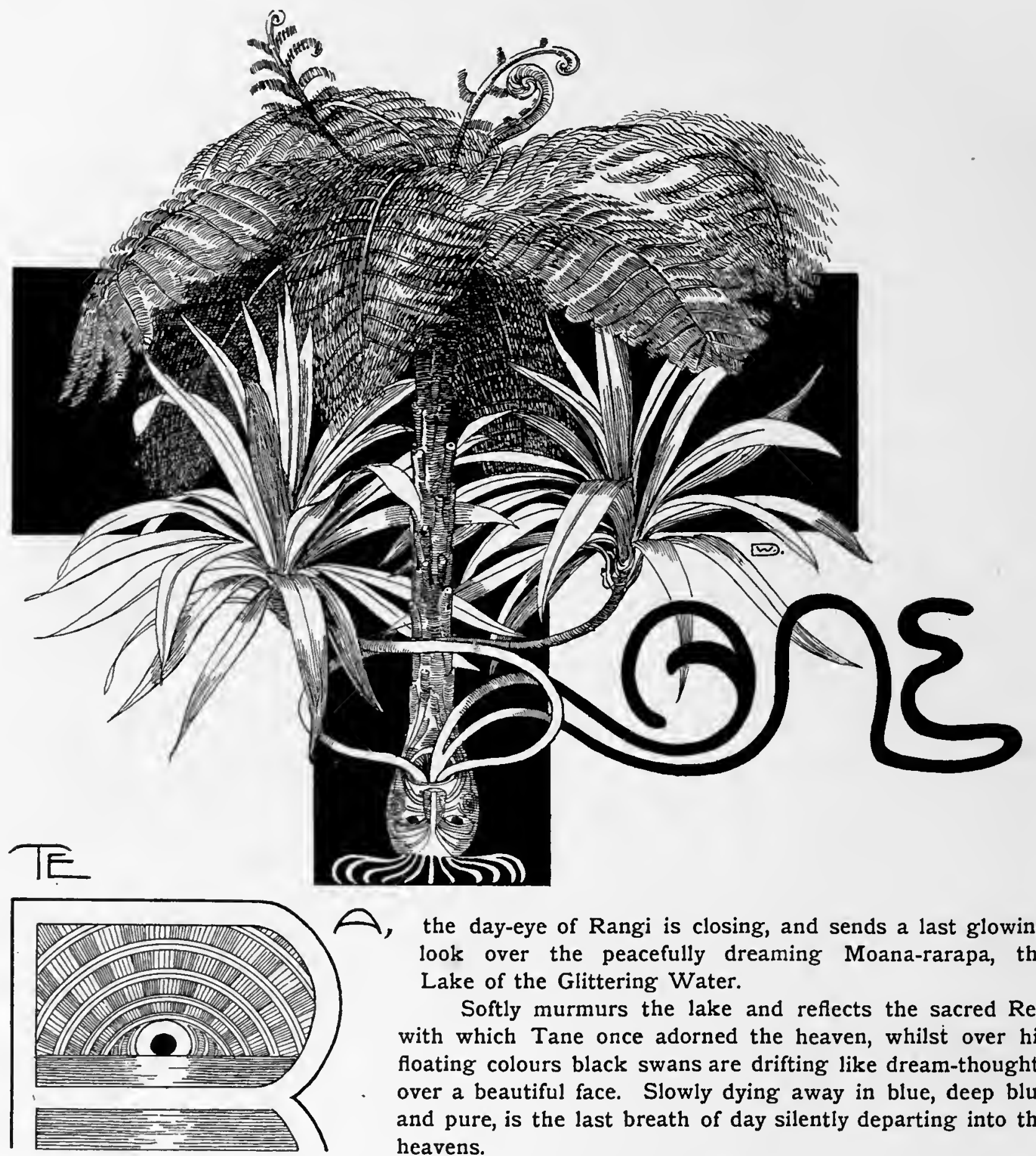

the day-eye of Rangi is closing, and sends a last glowing look over the peacefully dreaming Moana-rarapa, the Lake of the Glittering Water.

Softly murmurs the lake and reflects the sacred Red with which Tane once adorned the heaven, whilst over his floating colours black swans are drifting like dream-thoughts over a beautiful face. Slowly dying away in blue, deep blue and pure, is the last breath of day silently departing into the heavens.

A canoe is putting off the shore, and voices of children are heard leading it light-hearted with mirth and laughter and splashing of water over the lake, which looks clear and glittering green up to the stars. Softly now breathes the air, and the mirror is gone-the day has departed.

Muttering departs Hupene, our old friend, in dread of the darkness; with his mat he is covering our shoulders and he murmurs these words: 
THE CREATION OF THE STARS

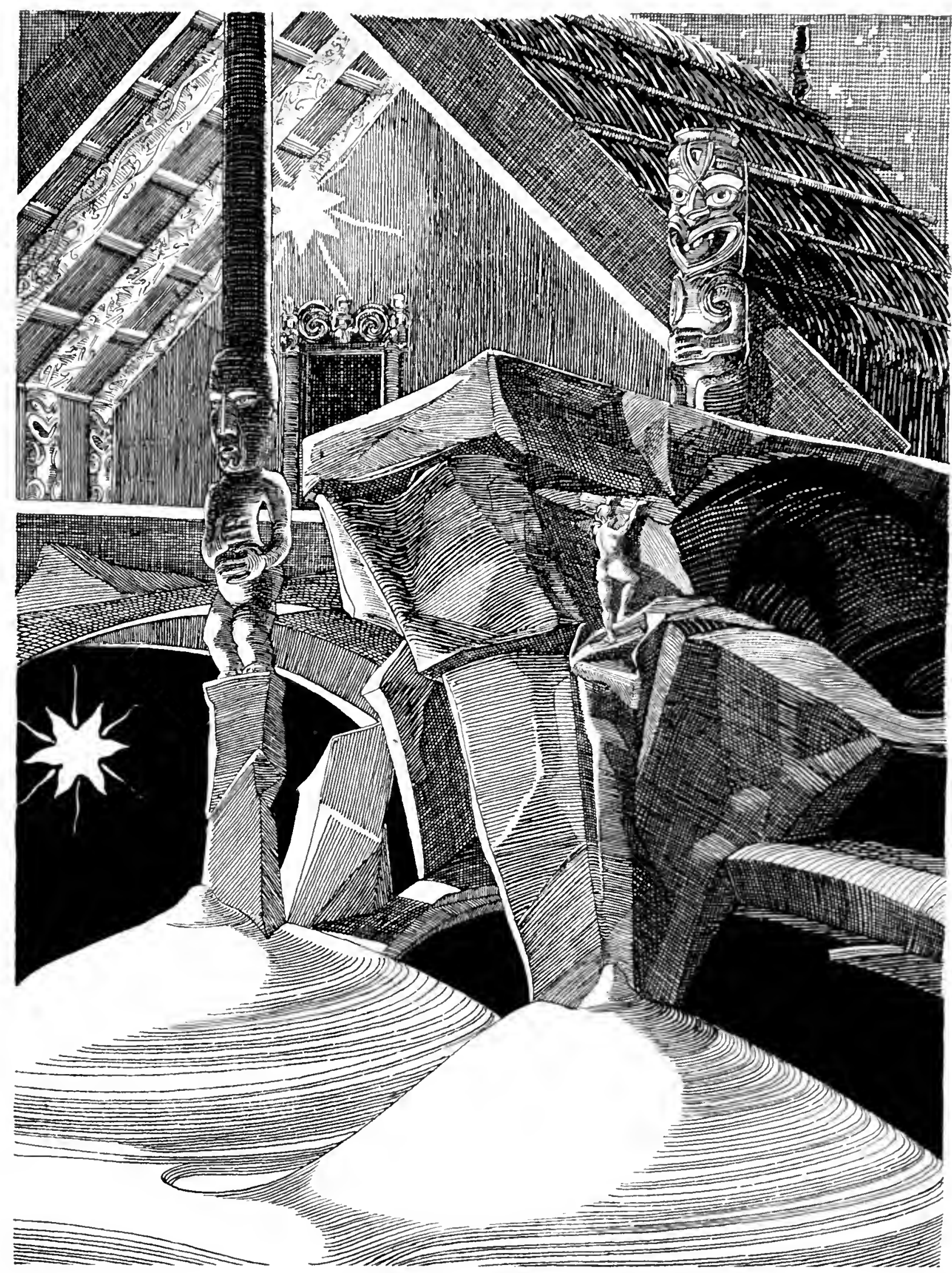


. '. 


\section{THE CREATION OF THE STARS}

"Remember, while you are watching the stars on the night-mat of Rangi, and know, great is the power of the god Tane-Mahuta, and his are the stars.

Remember, his are the stars." -

Bright shimmer the stars through the summer night, and the earth breathes freshness and sleep, leading the heart to rest, and it yet filling with longing; but from the heaven descends hope, promising the new day and the future.

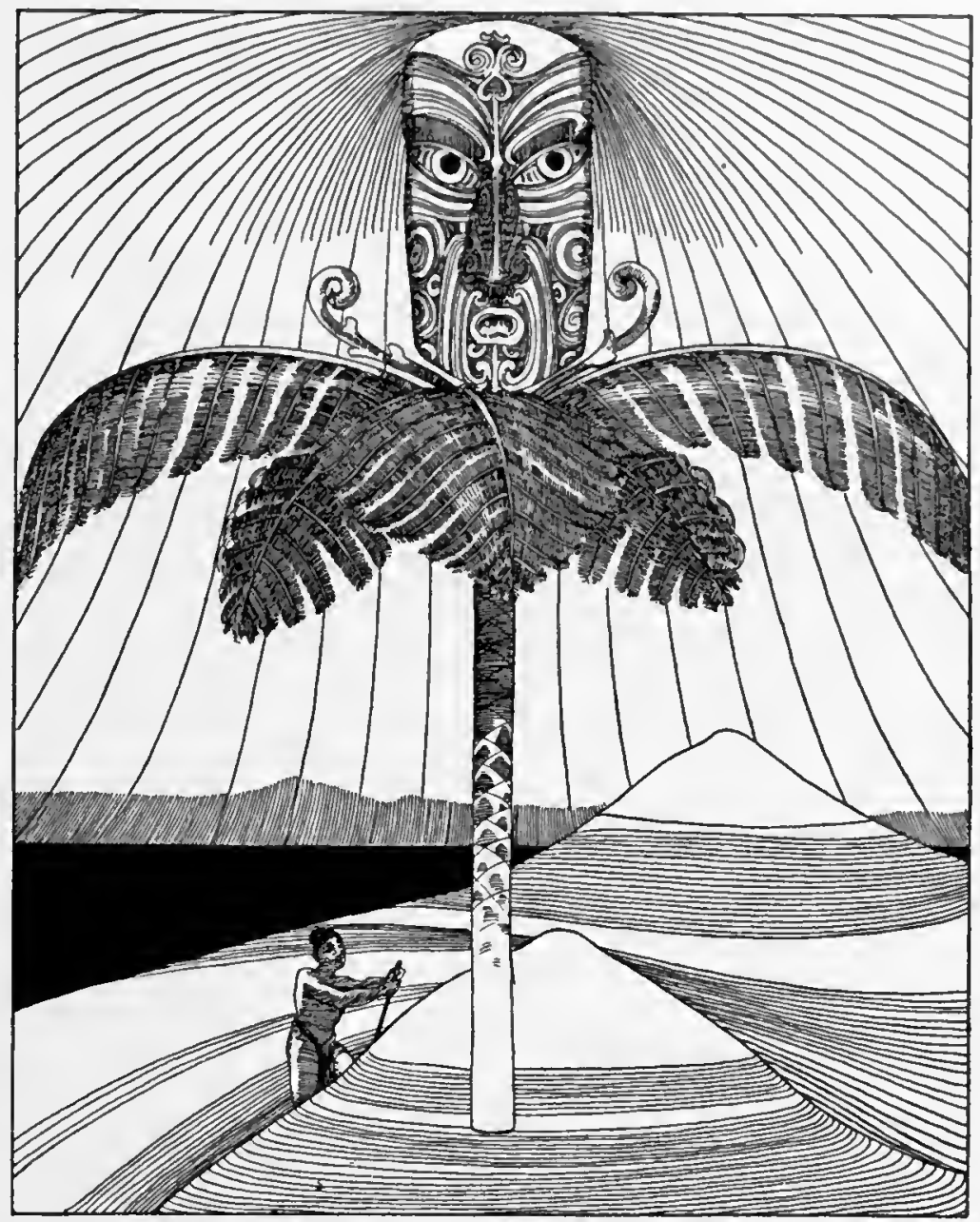

Tane once commenced his great wandering to find adornment for his father, the heaven, whom he beheld standing high over Papa, naked by day and lonely and cold by night, and he spoke:

"O, father Rangi, my heart is looking upon you in sorrow, for you are lonely and cold, and I will go in quest for adornments which shall make you beautiful to the eyes of Papa and her children." Thereupon he went on his way, and, whilst he was wandering through the ten heavens, he found Te-Kura, the Red Colour, and that he took back with him upon the earth. Here he rested for seven days and seven nights, and, when his strength was growing again, he commenced his work, and covered the heaven with the beautiful red colour. But behold, when he had finished this great work and descended again to earth, he let his eyes wander over the red sky, which was stretching now over Papa, and he found that this adornment was not worthy of his great father, and full of sorrow he took it away again leaving some of it only at Mahiku-rangi, the End of Heaven. He beheld now, when Rangi was closing his great eye, sending it down into the $\mathrm{Po}$, or when he called for it again in the mornings so that it burst 


\section{ANCIENT LEGENDS OF THE MAORIS}

forth out of the Gate of Day, that the beauty of his father at Mahiku-Rangi was wonderful, but ever and ever it disappeared by day and by night.

Seven days and seven nights he was watching the dying away and bursting forth again of Rangi's beauty, and then out of his sorrow he sang these words up to his father: "Oh, Rangi, still you are cold and dark and lonely from the first night, to the second night, to the tenth night, when your daughter Te-marama ascends again out of the Source of Living Water, so that you look down upon Papa silent and sorrowful. What adornment can I find for you, that you may be happy and beautiful, and gladden the heart of Papa, your loved one?"

After he had spoken these words he wandered forth again upon his mighty search, and all over the world he wandered, and farther and farther still he wandered, till he came to Tawhiti-nui, the Great Distance; and farther still, till at last he came to Te-Po, the Lower World. Here he found Hine-2-te-ao, the Daughter of the Light; she is the guardian of the Gates of the Lower World, and, tired from his long journey, he slept in her house.

In the darkness of night he beheld two beautiful stars shining forth; they were the children of Ira, and their names were Lonely South, and Shore of Heaven, the morning star, and his heart was glad over their beauty, so that his eyes could not sleep, and could not but rest upon them all the night.

In the morning he called Hine-a-te-ao, and showed her the two beautiful stars shimmering forth out of the darkness of the Po, and asked for them, for nothing could be more beautiful he thought as an adornment for his Father Rangi. Hine-a-te-ao answered: "Go, son, and take the stars!" And again he pleaded: "Oh, Hine, Daughter of the Light, show me the road that I may go and take the stars." And Hine-a-te-ao answered: "O, son, far is the way indeed! Go to the House of Tupu-renga-o-te-Po, the Growing Night: he is the guardian over the two stars, and his house is standing at Mahiku-rangi. There ask for the two stars, whose names are Toko-meha and Te-pae-tai-o-te-rangi; go and take the stars for your father Rangi."

After Tane had rested, and for seven days and seven nights strengthened himself through powerful incantations and many Karakias, he went on his way to Mahiku-rangi, to the House of the Guardian of the Stars, Tupu.

When at last he had found Tupu, he pictured the sorrows and the nakedness of his father, and asked him to give the beautiful stars to Rangi, and Tupu answered: "Oh, Tane, son of Rangi and Papa, the stars which you behold shimmering yonder are the sacred holders of the world; they are Hira-utu, Fish by the Land, Hira-tai, Fish of the Sea; Parinuku, Cliff by the Earth, and Pari-rangi, Cliff of the Heavens. Yes, it is my wish that you may adorn Rangi with yonder stars." And he gave him the Four Sacred Holders of the World, the stars

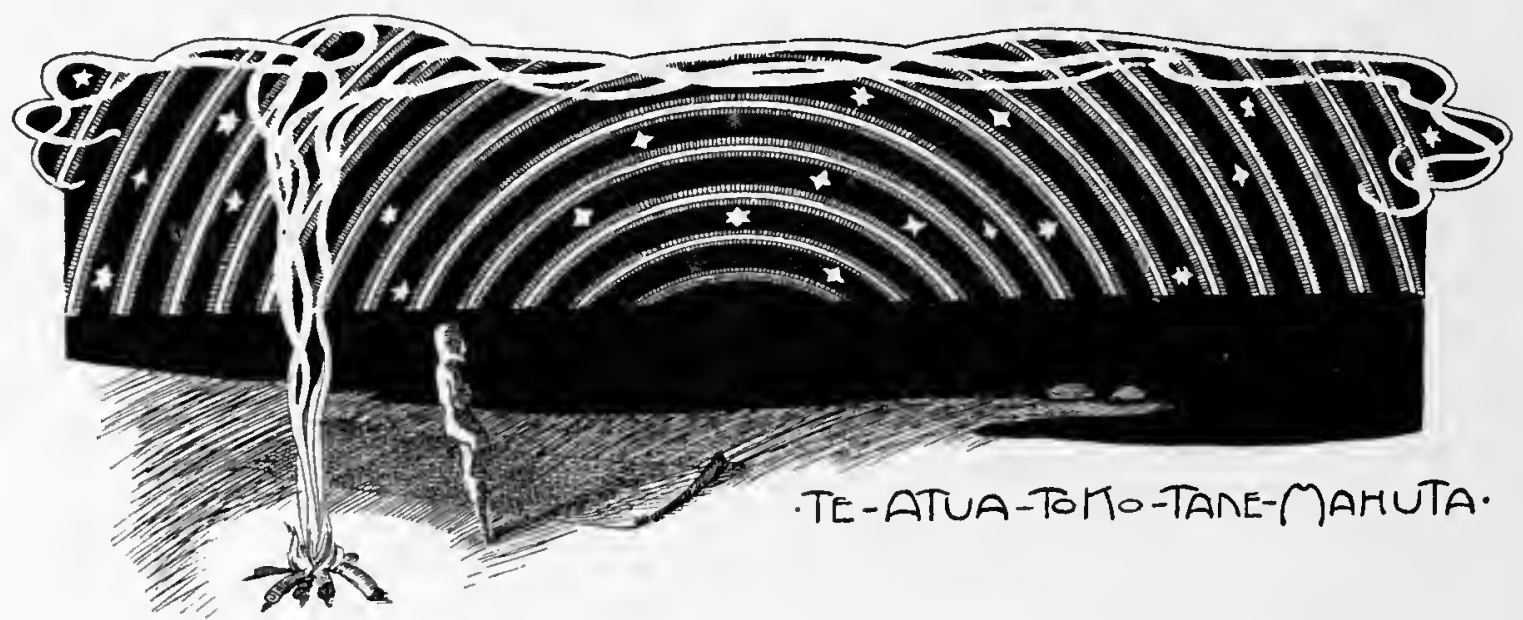




\section{THE CREATION OF THE STARS}

of the four points of the compass, and then he gave him the five stars, Ao-tahi, Puaka and Tuku-rua, Tama-re-reti and Te-waka-a-tama-rereti.

All these stars Tane took away with him and fastened the four sacred stars in the four corners of Rangi; with the other five he formed a cross in the South.

Many more stars brought Tupu, and Tane distributed them over Rangi from the summit of the mountains whilst still the Sun was standing high in the heavens.

And again sorrow filled his heart when his eyes looked upon his work, for again he found that the adornment was not worthy of his father Rangi.

But at last he had finished his labour and that was about the time when the Sun was again entering the Gate of Night. Resting upon Papa, he watched the beautiful sacred red appear again at Mahiku-rangi, and, when with the departing sun darkness again filled the world, his wandering eyes perceived how star upon star commenced to live and shine forth, till at last Rangi in wonderful beauty was stretching over Papa, and his heart was full of joy and happiness, and he sang: " $O$, father Rangi, your beauty is indescribable; in truth you are now the ariki of Papa, and all her children will love you!"

Thus had spoken the old friend on the shores of the glittering Moana-rarapa.

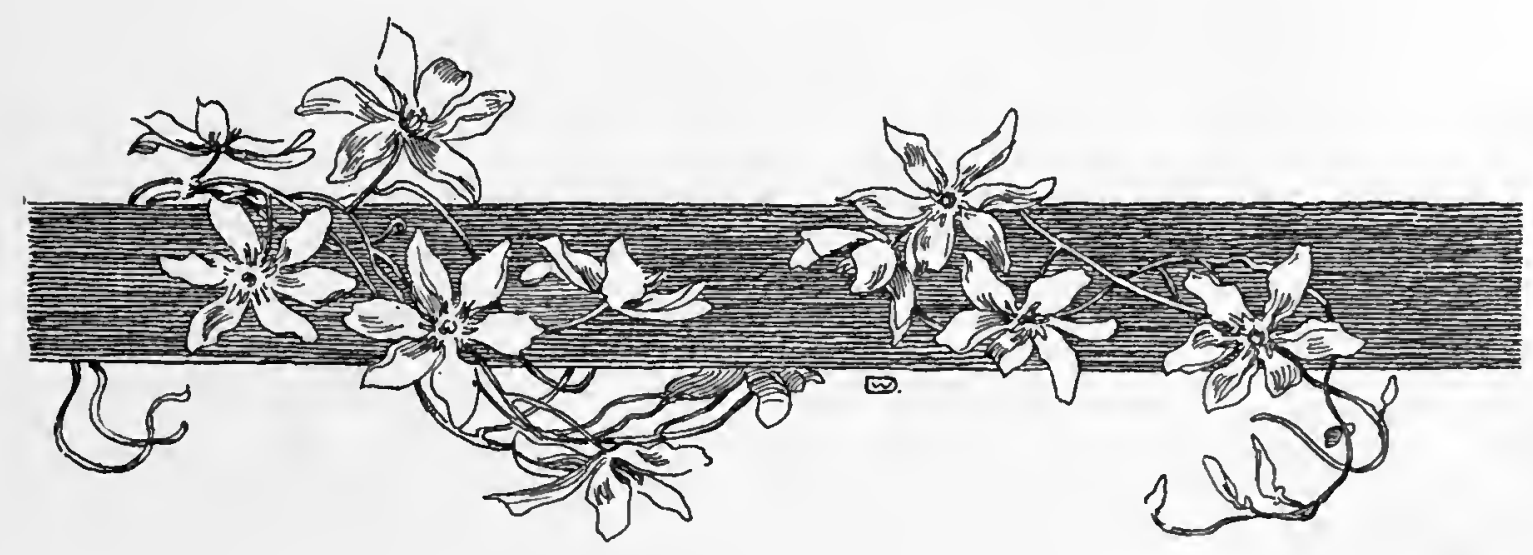




\section{THE CHANT OF RANGI-NUI}
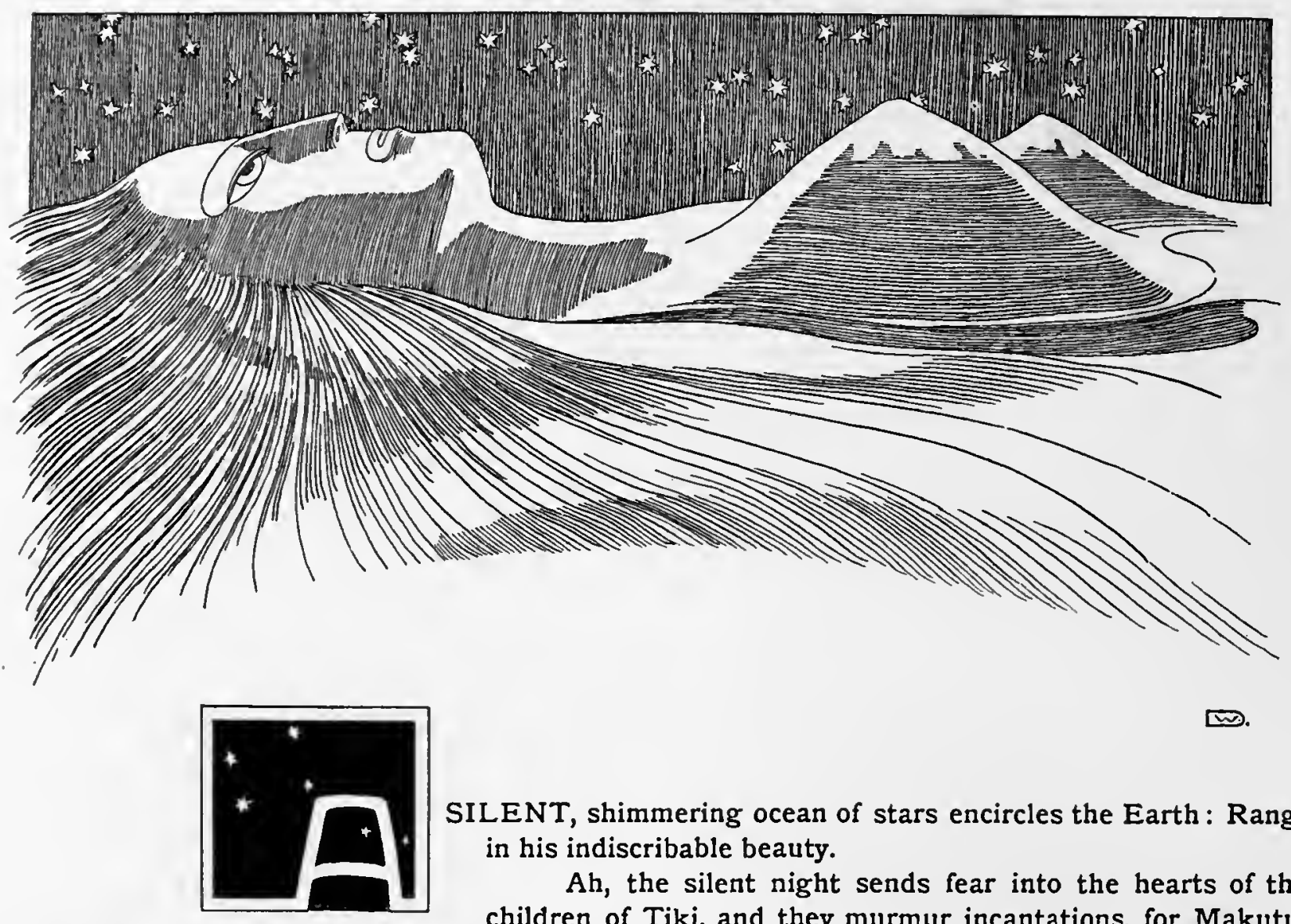

the terrible witchcraft, and the host of beauty of Tane-Mahuta's stars.

Of half-forgotten wisdom the old friend had murmured into the listening ear of the guest, while the people of his tribe had covered their heads and closed their ears; for dangerous it is to listen unto the wisdom :

"Ten are the heavens who are stretching over Papa, and they together are Rangi"- so had spoken the old friend.

The lowest heaven is Tawhiri-matea, the dwelling-place of the god of the winds. It is the heaven of the Floating Air above the earth, and it is the heaven which gives birth to the sacred red at Mahiku-rangi.

Each heaven is divided from the next by a transparent roof, and so divided from the first is the second heaven, which forms the path for the Sun and the Moon, and which is the dwellingplace of the heat of the day.

The third heaven is the place for the lakes and the waters. The God of Winds is often rushing over them from one end of the heavens to the other, and that makes the waters spray and splash, and causes them to fall as rain down upon earth. Rehua once, in terrible wrath, stamped upon the bottom of this heaven so that it broke, and all the waters rushed down upon the earth as a Deluge.

In these three heavens is Maru, the governing god; from here it is that he inspires the children of earth with great deeds, that the spirits of the slain braves may live here as stars on the heavens of Maru, the God of War.

The fourth heaven is Tawhaki, and from this heaven are the spirits of man sent down upon Earth to enter there into the children, new-born to life. 
THE CHANT OF RANGI-NUI

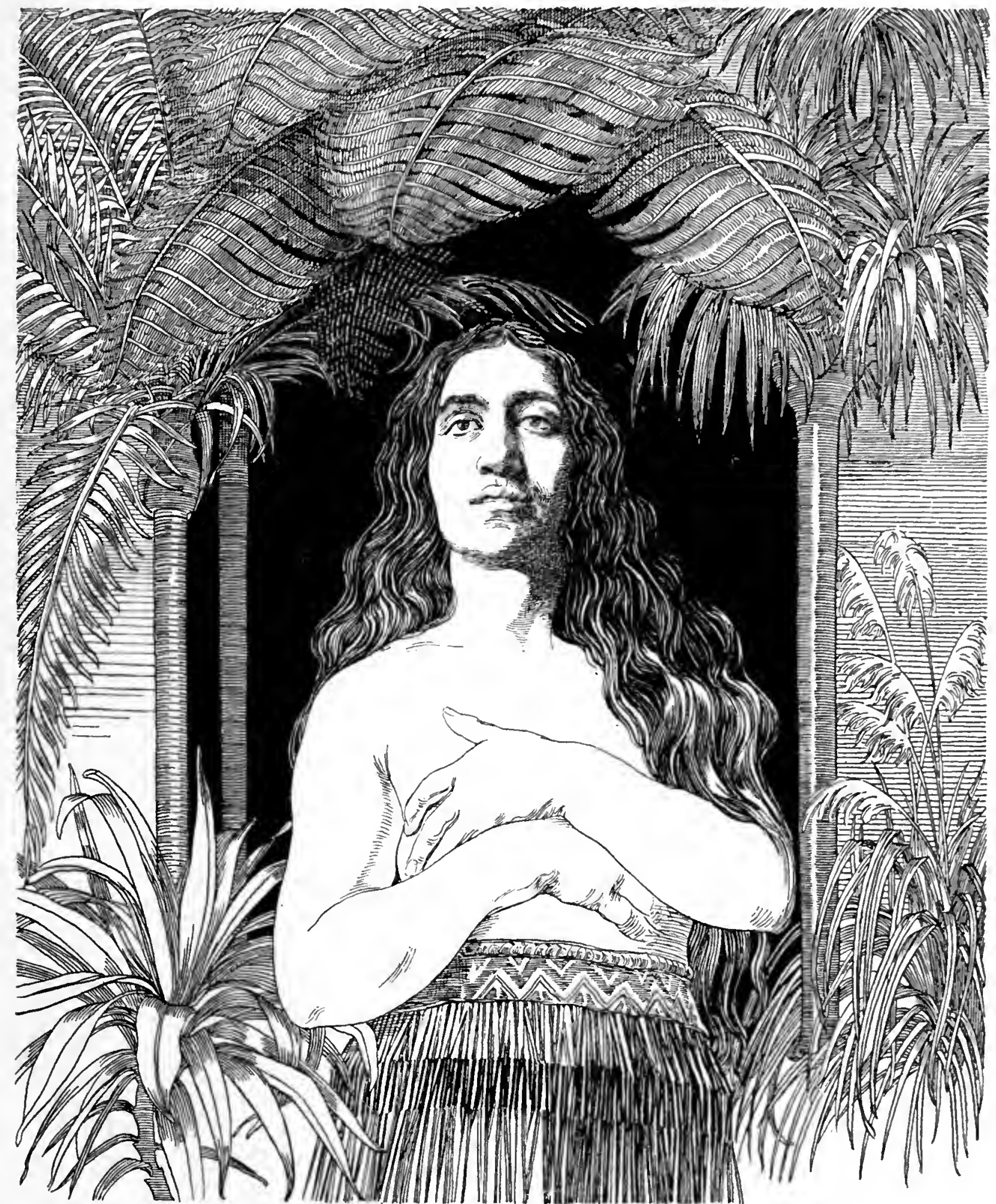

w. 
ז 


\section{THE CHANT OF RANGI-NUI}

The next heaven is the home of the lower and lesser gods, who are the slaves of the gods who live in the highest heavens.

The sixth heaven is the dwelling-place of Tawhaki, and it is from here that he governs the host of inferior gods and atuas who work and shape, and help and hinder, the destinies of Tiki's children. To these three heavens of Tawhaki are directed most incantations and songs and Karakias of the people; high up into these three heavens also reaches the power of the Tohungas of great Mana, and their incantations often compel the gods to work good or evil according to the will of the Tohunga.

Over the next heavens is Rehua the ariki.

Rehua is the god of food; therefore is he the ariki over the gods, and many were his victories over Maru, the God of War, for many were the spirits of the slain heroes who were wandering up to the heavens of Maru, there to become stars, and who changed their mind and followed the call of the god Rehua, for Rehua is the God of Food. Truly, he is a powerful god!

It is in the seventh heaven that the spirits of men are created: here they commence their lives, which they continue in the next heaven, their wonderful dwelling-place, Aukumea, the paradise of the spirits before they descend into the forms of men.

In the next heaven live the host of the atuas, the working-power of the great gods who are living in Tuwarea, the tenth heaven, and the sacred edifice of the highest gods.

Rehua is the commanding god in Tuwarea.

All the heavens together are Rangi, a son of Te-Po-nui, the Great Night. Thus had spoken the old friend.

The endless beauty of the "shimmering vestment" is the birthplace of the host of spirits, and the abode of the gods, and it is fearful for man when their spirits follow their longing eyes toward the glittering Grandness, trying to penetrate Hine-nui-te-po.

Maui once entered Hine-nui-te-po, trying to penetrate her, so that she might be killed and man may live for ever; but that was the death of Maui. With the gods and spirits communicates the Tohunga, and his wisdom renders him Tapu. Far may his thoughts wander when his eyes are closed and opened again toward the wisdom, which has been handed down from the whare-kura since the time of Te Kore-the Nothing; and all-powerful, defeating the gods themselves may his incantations and Karakias be when he, squatting at the sacred place, before his carved god-stick, murmurs the great incantation Waka-rawhiti, the Mouth of the East. $\mathrm{Ha}$, the power of it grows like the Sun out of the darkness, and conquers all but Hine-nui-te-po, who cannot be conquered - but night and ioneliness are dangerous to all.

Golden dawns the east, and with the sacred red at Mahiku-rangi appears Ngawai.

She comes toward the shores of the lake with laughing eyes, and speaks:

"Whereto wander the thoughts of my friend? His eyes are looking into the distance, but they can see nothing, for the distance is hidden by the morning-mist."

The eyes, Ngawai, follow the thoughts into the past of your people, and she also is hidden to me, and my mind is pondering over the little wisdom I received, wisdom out of the whare-kura.

Ngawai smiles, for not always does the thought of the gods and spirits inspire terror. Descent from the great ariki and from the Rangatira-tohunga gives security to man; and out of Ngawai's eyes it flashes: man is powerful in spite of the gods. "Do not let your mind dwell with the deeds of the gods and the heroes of my people, but open your heart to the incantations which have soft power over the hearts of men."

Tell me, Ngawai, of Tane, who adorned his father Rangi so beautifully; tell me, my friend, of his love to Papa.

"Come into the shadow of the trees, my friend, the shadow of Tane-mahuta's children, while I will tell you of his love to Papa.

Come into the shadow of Tane-mahuta." 


\section{TANE-THE CREATION OF NATURE}

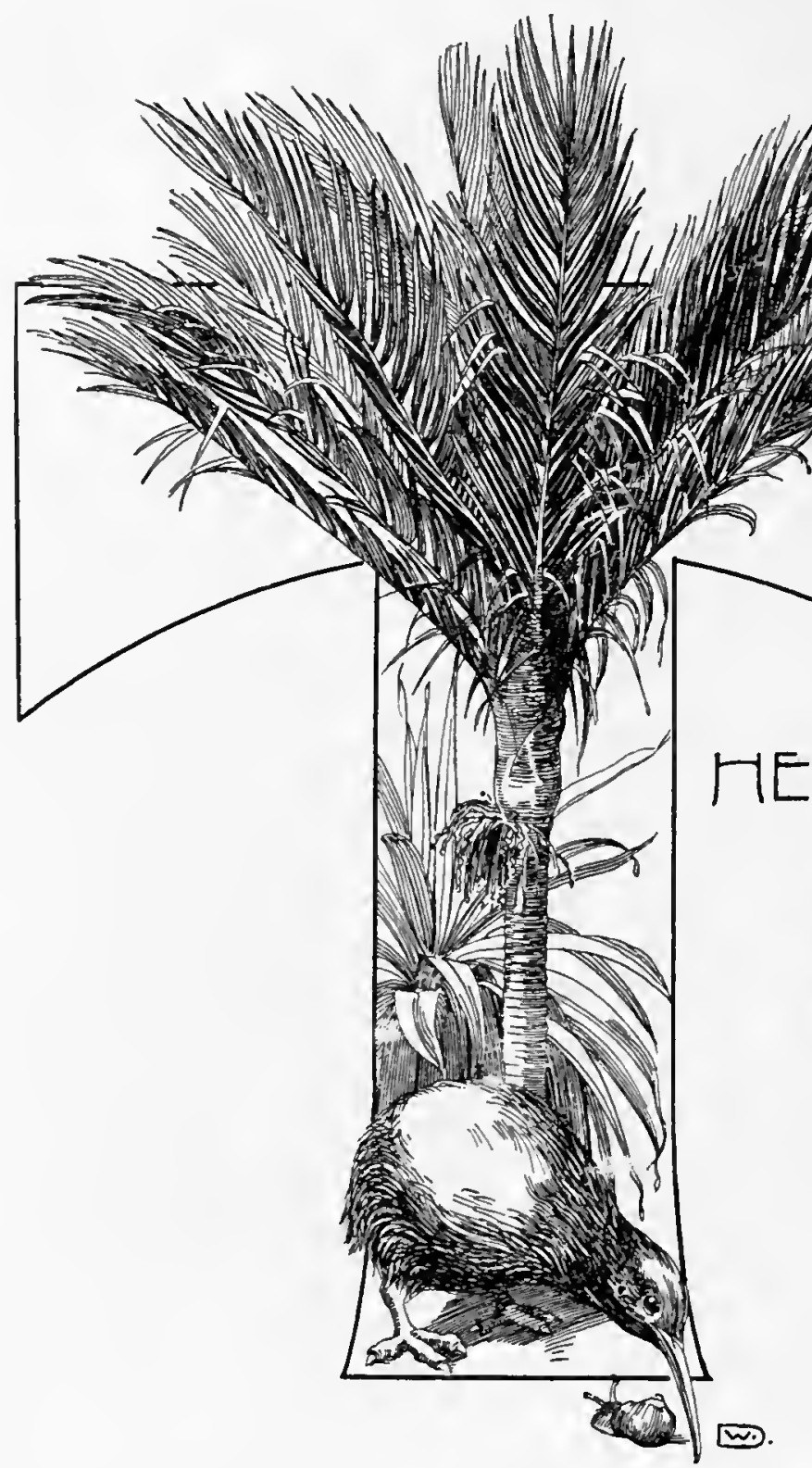

ODPOWER of Tane lifted his father Rangi high above the mountains - oh, high above the mountains, clad in snow he lifted him with the help of the gods who dwelled above the earth.

Ah, bare now was Rangi and naked-oh, he was beautiful and vast, but lonely and bare, and Tane adorned him with the stars; oh, then was Rangi very beautiful indeed!

From his great work Tane was resting upon earth while his eyes were wandering over his mother, and his heart grew sad again, for he beheld that she lay naked under the eyes of Rangi and the gods.

$\mathrm{Ah}$, his love for his mother was great, and he pressed his head to her bosom and spoke: "Oh, mother, I will not that you sorrow any more over your nakedness for I will adorn you with great beauty; do not sorrow any longer, oh mother, Papa."

Thereupon he went into the Great Distance, and became the father of the lakes, the Water of the Many Faces; and many of these glittering faces he distributed over Papa. Faces, smiling at Rangi by day, and blushing up to him at every new morning-look my good friend, how the Moana-Rarapa is reflecting the beauty of Mahiku-rangi whilst Rangi is laughing down upon Papa out of his Eye of Day: ah, are they not lovers?

But again Tane wandered into the Great Distance, till he found the Gentle Noise of Air; and taking her to wife, he founded the family of the Multitude of Trees. Their sons were the Totara-tree, the Manuka, the Rimu, and the Kauri-tree: ah, look at the tree under which we are resting; see the majestic beauty of the Kauri, the child of Tane! And their daughters were the Kahiku, and the creeper and the vines. 
TANE-THE CREATION OF NATURE
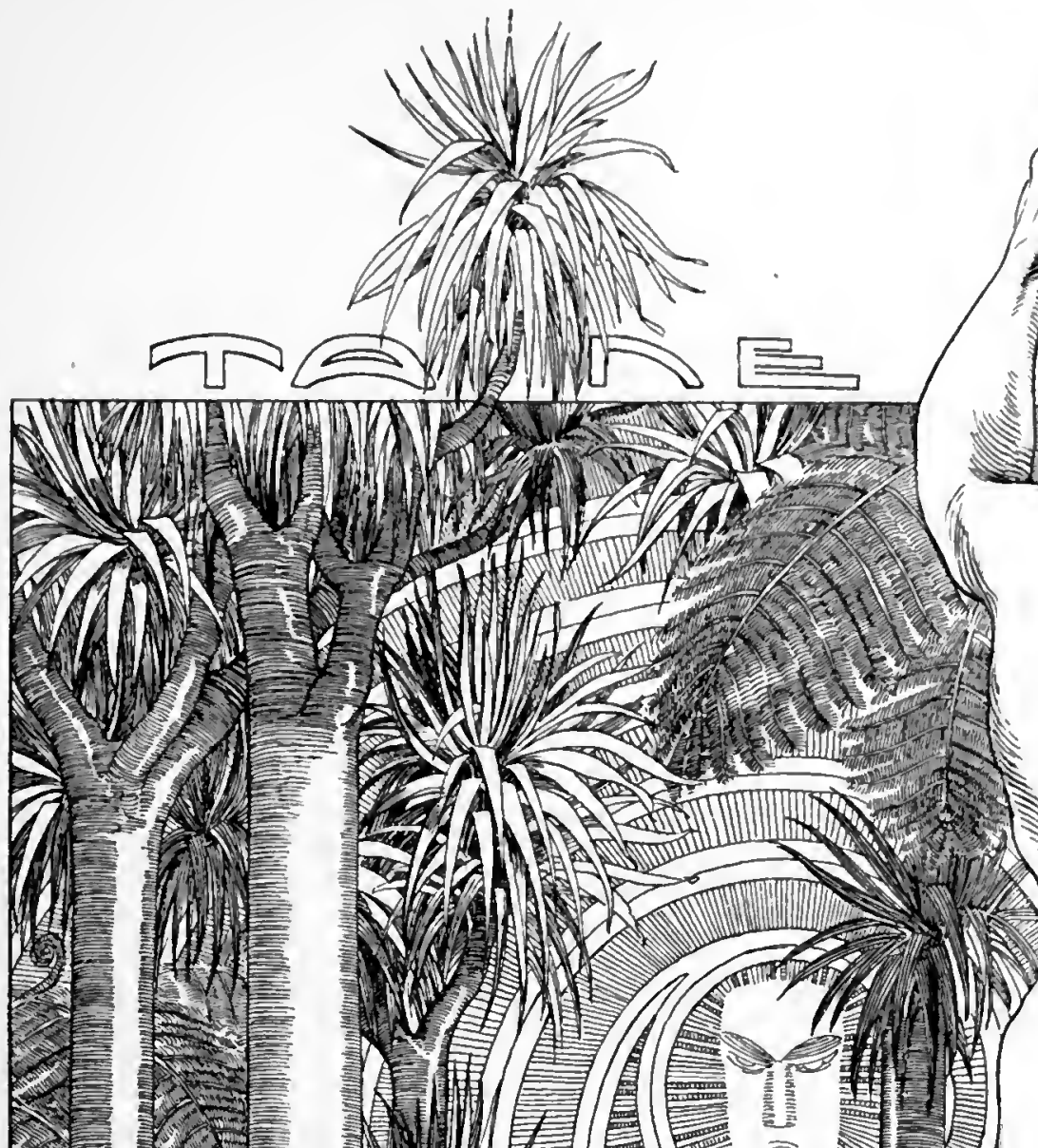

tit
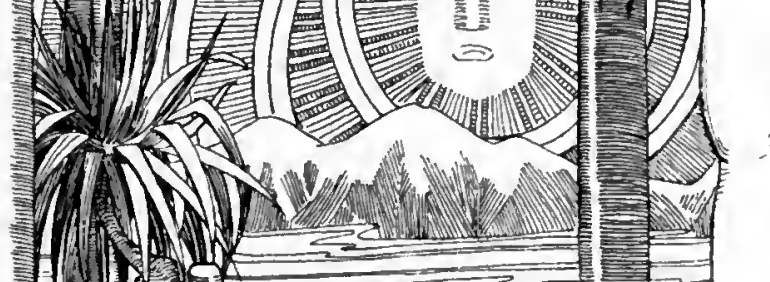

IN)
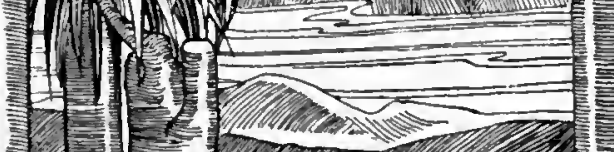



\section{TANE-THE CREATION OF NATURE}

Whilst the Multitude of Trees were growing up into maturity, Tane rested not till he found the two sisters, the Wanderer in the Sky, and the Wanderer in the Brook, and they gave him his children, the birds.

There, friend, do you hear the sweet sounds? There? - there now; everywhere - ah, it is the black Tui; and there, do you hear the gentle noise and soft clapping of wings over our heads? It is the folk of the Kererus, the wild-doves; ha, listen to their happiness! Come farther into the green shade, my good friend, that your heart may be filled with the beauty of Tane.

Yes, my friend, when Tane had founded these families, then he took them back to her who was still lying lonely and naked, and now he began his great work. Ah, let us wander under the shade of Tane, that your eyes may see how the Multitude of Trees are covering Papa like a beautiful garment, spreading shades and giving happiness to the children of Tiki; perceive in the wonderful garment the great god-power of Tane-mahuta.

Close your eyes, my good friend, that Ngawai may show to your mind the path upon which it may perceive how Tane distributed the multitude of his children over the earth. Ah, ha,-can you perceive how he puts their feet into the ground? $\mathrm{Ha}$, ha! They will not stand! They lift their heads up to Rangi and cry, and will go whither it pleases them; ha, ha, my friend, they are rebellious, and fight with each other, and run away, for they do not like to stand and grow, and give garment and coolness to Papa, ha, ha!

Ah, can you perceive how Tane looks upon his work of the first day, and sees the rebellion? Can you perceive his rage, the terrible rage of the god?-ha, ha!

$\mathrm{Ah}$, he is wending his way back, tearing his children out of the ground and throwing them down, tearing and throwing, and then, when the sacred colour appeared again at Mahiku-rangi, he began his great work over again! $\mathrm{Ha}$, ha, my friend, ha, ha, can you perceive how he began his work? Listen: he took his children and put them into the ground again, but, ha, ha, oh, he put their heads now into the ground, so that they must stand upright and stretch their feet up to Rangi; ha, ha, could they move now ?-and fight?-and run away? Ah-their hair commenced to grow into the earth and took root, and their mouth drank the dew-the tears of Rangi for Papa-and sent it up into the limbs and feet as strength and life, and the feet grew long and branched off and covered themselves with leaves. Ha, my good friend!

Ah, my good friend, when Tane saw his children now, then came joy to his heart, and all over Papa be planted his children, and they grew, and took the earth to their mother.

Oh, beautifully now was Papa dressed in her vast garment, and greater still grew the love of Rangi, and he sent the rays of his Eye of Day down upon her, and created the flowers.

O, my friend, follow Ngawai into the darkness and the pleasures of Tane-mahuta's creation; look, all the life of the forests and all the life in the air is his, ah, he is the great friend of man, he is the god-power of Nature.

Tane, the great son of Rangi.

Tane, who loved Papa.

Tane, the friend of man."

A soft murmuring was Ngawai's voice, murmuring to the leaves of the trees; murmuring of that what the birds had told her; murmuring to the spirits of the forest, who all are children of Tane-mahuta. 


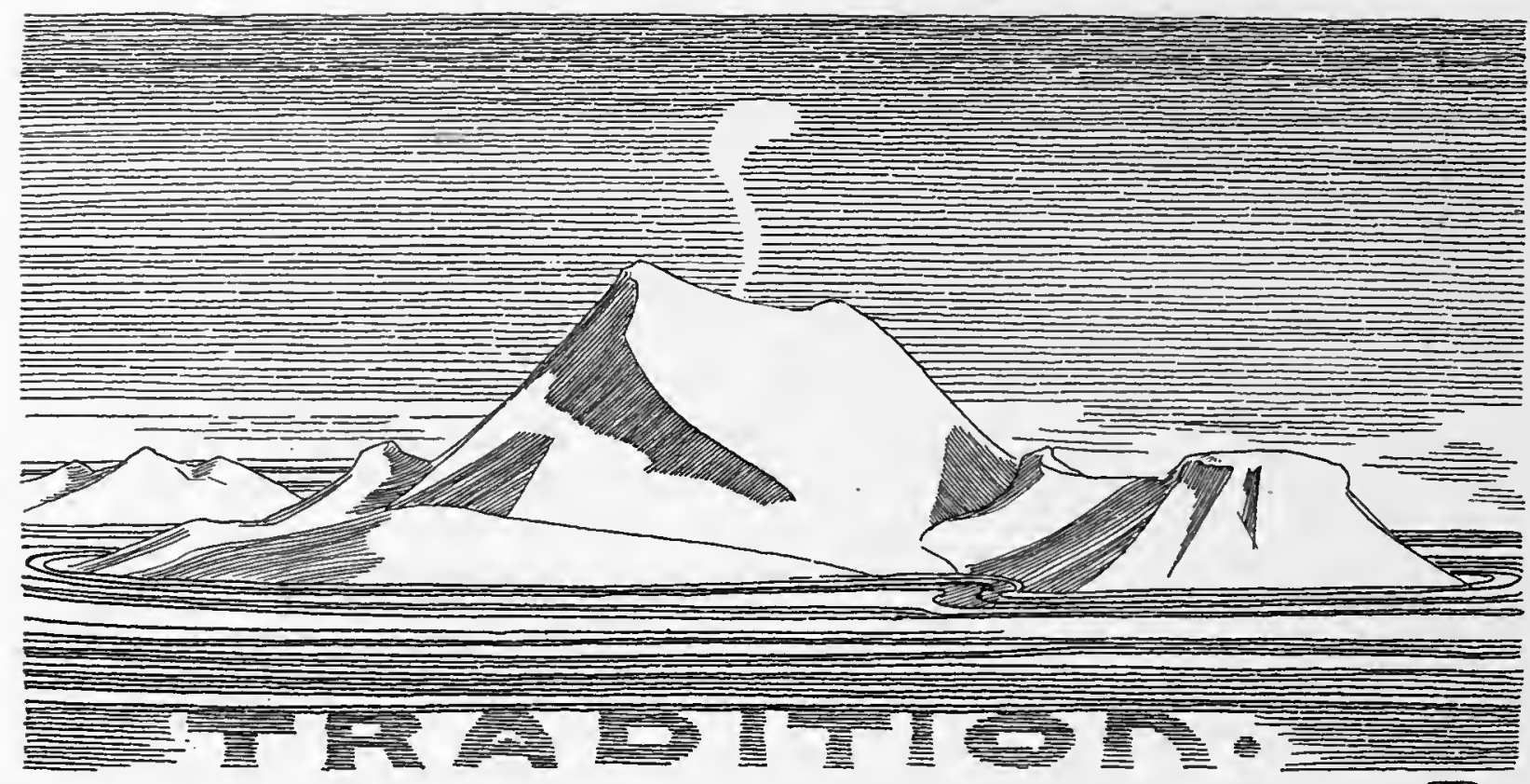

w.

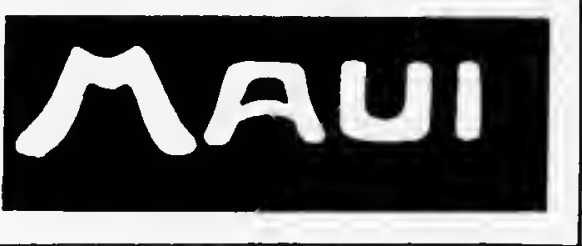

is the hero of the Maori people: he is the God of the Sun. $\mathrm{He}$ is Maui-roto, the Night-sun, the hero of the Lower World; and he is Maui-waho, the Day-sun, the hero of the light.

Maui-roto, living in the Lower World, created the Earth, which has, like the Sun, a body of granite; and Maui-waho then nourishes her with his blood, which he streams down upon her as the red Evening-glow. This Evening-glow, covering the earth, does not.die away with the Sun, but it cools and forms a new layer upon Earth, and thus, with layer upon layer of Evening-glows, he nourishes his child. It is upon the mountain Tongariro that this radiance lives most brilliant and long, and that is the reason why Tongariro became the possessor of the highest Tapu, the sacred mountain of the Maori people.

Hine-nui-te-po is the Goddess of Night, and the whole world is her pataka (storehouse). She has commanded her slaves that, when a man came, crawling with his head forward, they should let him go into her pataka and not kill him, for he would be an atua and of great tapu; but should they perceive a man standing upright in his canoe, they should take him and put him to death.

Now a man came-it was Maui-potiki (Maui the infant), the Morning Sun; and he came crawling into the world, the pataka of Hine-nui-te-po. Head foremost he came, and, therefore, the slaves, seeing that he was an atua, let him into the world unmolested. But Maui-potiki ascends and ascends up to the very high, of the mid-day, and in his canoe he commences his descent. Lower and lower he went, standing upright in his canoe, and was at last seen by the slaves of Hine-nui-te-po. Out of Maui-potiki, the Morning Sun, has grown Maui-mua, the Evening Sun, and he now is captured by the slaves and pressed to death by Hine-nui-te-po.

The night swallows the evening.

But Maui-potiki, as Morning Sun takes revenge, for he steals off the sacred fire of his ancestress Mahuika; he returns to the world and puts fire to Hine-nui-te-po.

The night is burnt to death by the dawn of the morning. 


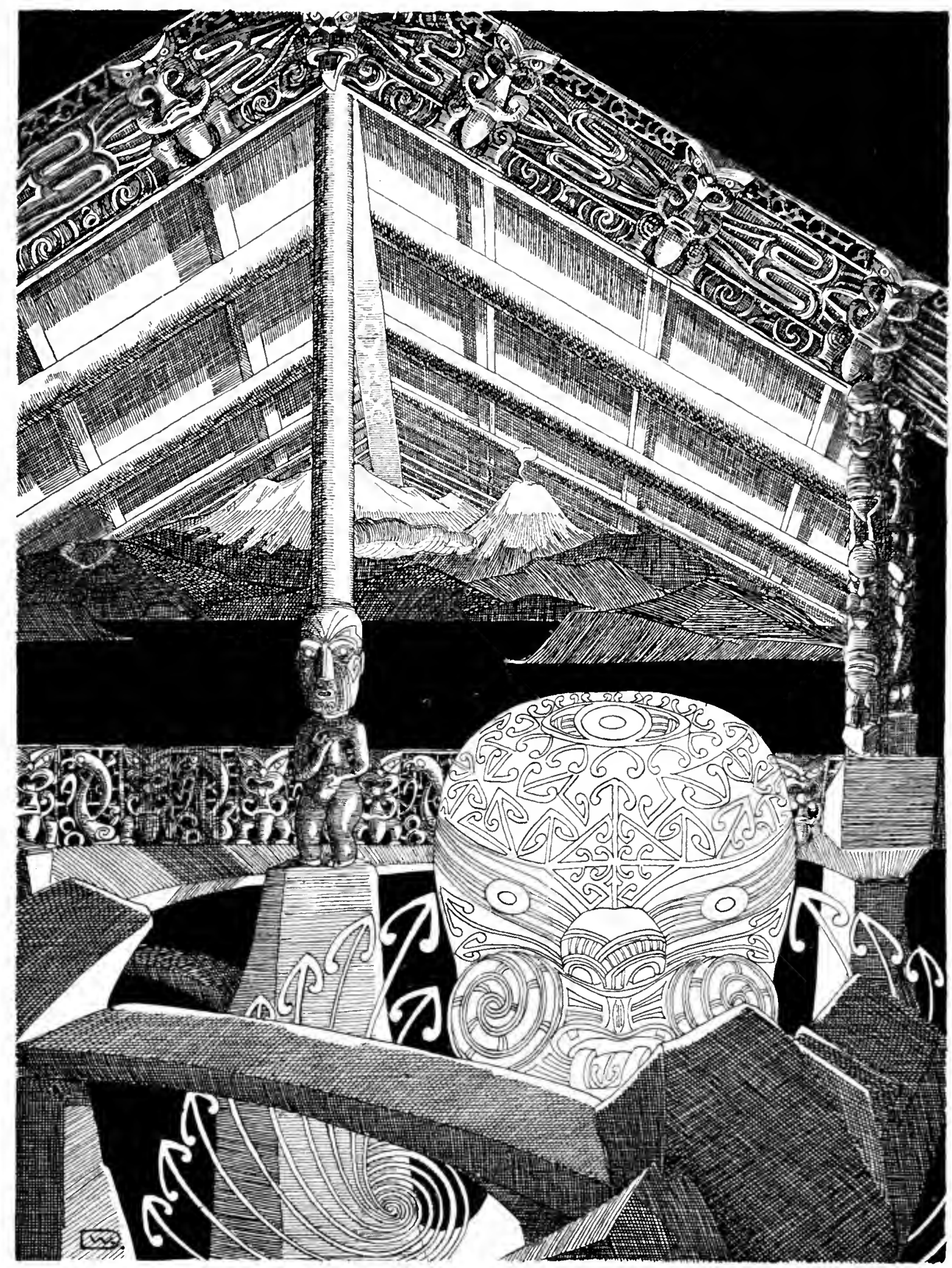



VIII

MAUI-THE CREATION OF NEW ZEALAND

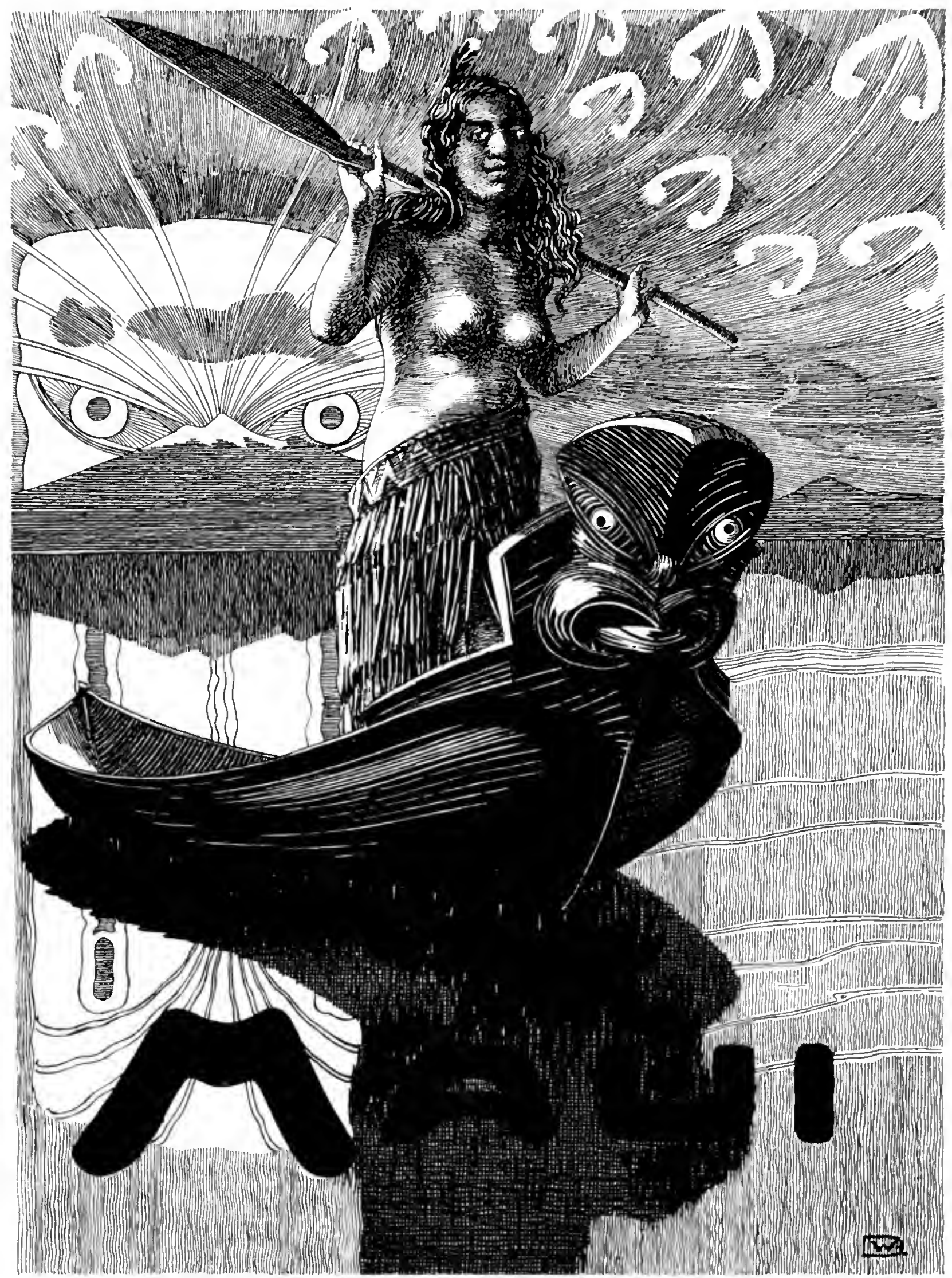




\section{MAUI-THE CREATION OF NEW ZEALAND}

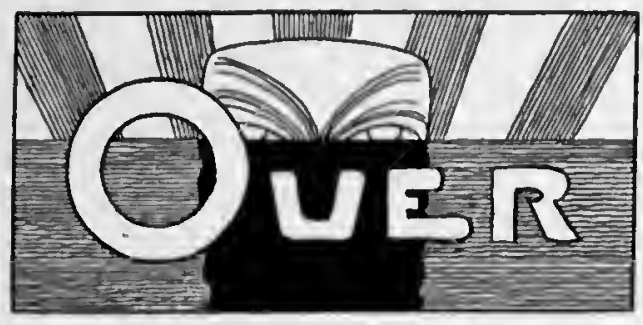

the sky shoot the first golden rays of the Sun whilst our canoe is gliding up-river and Honewaka is singing :
"Who is paddling my canoe along the river?
It is Hine, who takes my heart away from me!
O Rangi, send down thy dark clouds of rain,
That my dear love may not depart from me !-
$O$, I wish the water were heaped into waves
So my dear one will not go in haste from me."

Honewaka is leader; standing in the middle of the canoe, in his hand the greenstone-mere, he is chanting mighty songs of encouragement to the oarsmen, and these are repeated by them whilst paddling to the music, and the canoe glides joyfully under chanting and merrymaking, between the cliffs with the overhanging tree-ferns and ratas.

Honewaka is a leader of great mana; he knows every ripple in the river, and he knows men. He knows where the canoe glides onward whilst the spirits of his men are not in the paddles, and he knows how to incite their spirits by powerful songs so that, when the rapids are fighting their strongest, the spirits of men uniting to their greatest strength in the paddles will be victorious.

There rushes a rapid.

The eyes of the leader commence to roll; his weapon shakes; his breath is short, as he sings:

"Who is paddling my canoe along the river?"-and the crew, putting force into the paddles, answer: "It is Hine, who takes my heart away from me!"

The water rushes and foams around the canoe, and the singing, the chorus, and the paddling, follow the quick time-beating mere: quicker and quicker.

Honewaka, with rolling eye, makes a sudden bound, shouting:

" $O$, she is beautiful-beautiful!"-and half the crew changes the paddle with the strong and elastic tokos (punting-sticks)-one voice crying: "O, Hone, tickle her!" The crew laughs, but with the jest seems to come sudden life into the paddles, greatly assisted by the force of the holding and bending tokos.

Hone, excited now and with furious gestures, shouts :

"O Rangi, send down thy dark clouds of rain," Quicker and quicker, excited by Hone's singing, quicker and quicker pull the paddles, and amidst the shouting chorus, under the force of the powerful shifting and bending tokos, battles the canoe through the rapid.

Now the point is reached where the strength of the rushing waters is greatest, and the canoe will not move. Honewaka with greatest excitement cries :

" $O$, she is tall like the rata."

The crew, answering wildly: "It is Hine, who paddles my heart away with her."

Hone: "O, she is lithe like the toe-toe."

Crew: "O, Rangi, send down thy dark clouds of rain."

The spirits of the men are roused, and the roaring rush of the rapid becomes harmless under the steady living power of the paddles and the mighty pulling of the bending and trembling tokos. Into the silent, reflecting calmness of the higher water-reach the canoe suddenly shoots.

Ngawai, sitting in the prow, folds her arms over her paddle, and looks listlessly in 


\section{ANCIENT LEGENDS OF THE MAORIS}

the trembling and rushing waters, and smiles. Now the beautiful calm of the silent reach is gained; and the voice of Honewaka is low, mingling with the distant rolling of the rapid, as he narrates the story of the Taniwha, who lives in the caves of the rapid, and who has swallowed many a brave, when his song was not powerful enough or was displeasing to the Taniwha (water-monster). Then she broke the canoes on the large stones and took the strong man and beautiful women into her dark cave for food. Disdainfully looks Ngawai back, for now the battle is won, and women despise the conquered foe, be it man or spirit.

Great is the power of the Spirits who live in the image of a beautiful woman; greater is the power of the spirits awakened by incantations to the gods; and the power of man lies in the incantations which capture the gods into their weapon-but twice powerful is such a weapon when used in the service of a beautiful woman.

The distant rolling of the rapid now sounds like happy laughter of beautiful women far away over the water.

"Haere-mai, me o tatou mate" comes in the evening the wailing welcome from the Maori pa on the cliffs.

"Long is it, friend, since a man of your colour came to me, a great Tohunga-pakeha (white priest), and he took great pains to teach me the words of his Truth.

The words of his god.

I was young then, and Takakopiri, who was then so old that he could remember $\mathrm{Te}$ Repo-repo, the large war-canoe, growing still as a tree in the forest, had given to me the wisdom of the ancient. It was given to him by his grandfather, the Tohunga, Te-puha-o-te Rangi, whose mana was so great that people, saluting him, rubbed noses only against his knee-he was a great Rangatira.

"Long and marked with many teeth was the waka-paparanga-rakau, the board, recording the ancestors of Te-puha-o-te Rangi, leading back from ancestor to ancestor to Maui, who came from Hawaiki and who is the father of this land, which is called Te-ika-a-maui, or Maui's fish; and leading still further, up to the gods.

The wisdom, my listener, is born at Hawaiki.

Many a time died the moon, my friend, and was born again out of the Living Fountain of Tane Mahuta, while I was asking the words of the book.

Yes, beautiful is the Truth!-

But endless to count since then are the Floods who came down the river when his great Father, the mountain Ruapehu, shook off his white garment of snow, and my flesh has dried to the bones. Yes, friend, I loved the Truth of the white Tohunga; but she was not like a woman to me: she gave me no offspring.

$\mathrm{Ah}$, the multitude of voices of the past are in my heart, and my hands can touch the spirits of my ancestors, as they can touch my waka-paparanga-rakau; and they come and feed me with joy, like children feed the aged, and my heart is glowing with the power of my ancestors-of Maui the Strong.

Ah! his great power attempted his greatest deed: to take the heart of Hine-nui-te-po, that man may live for ever; but his incantations were overcome by the Mother of All, and she swallowed him, as she swallows all-Maui-i-tiki-tiki-a-taranga." 
MAUI-THE CREATION OF NEW ZEALAND

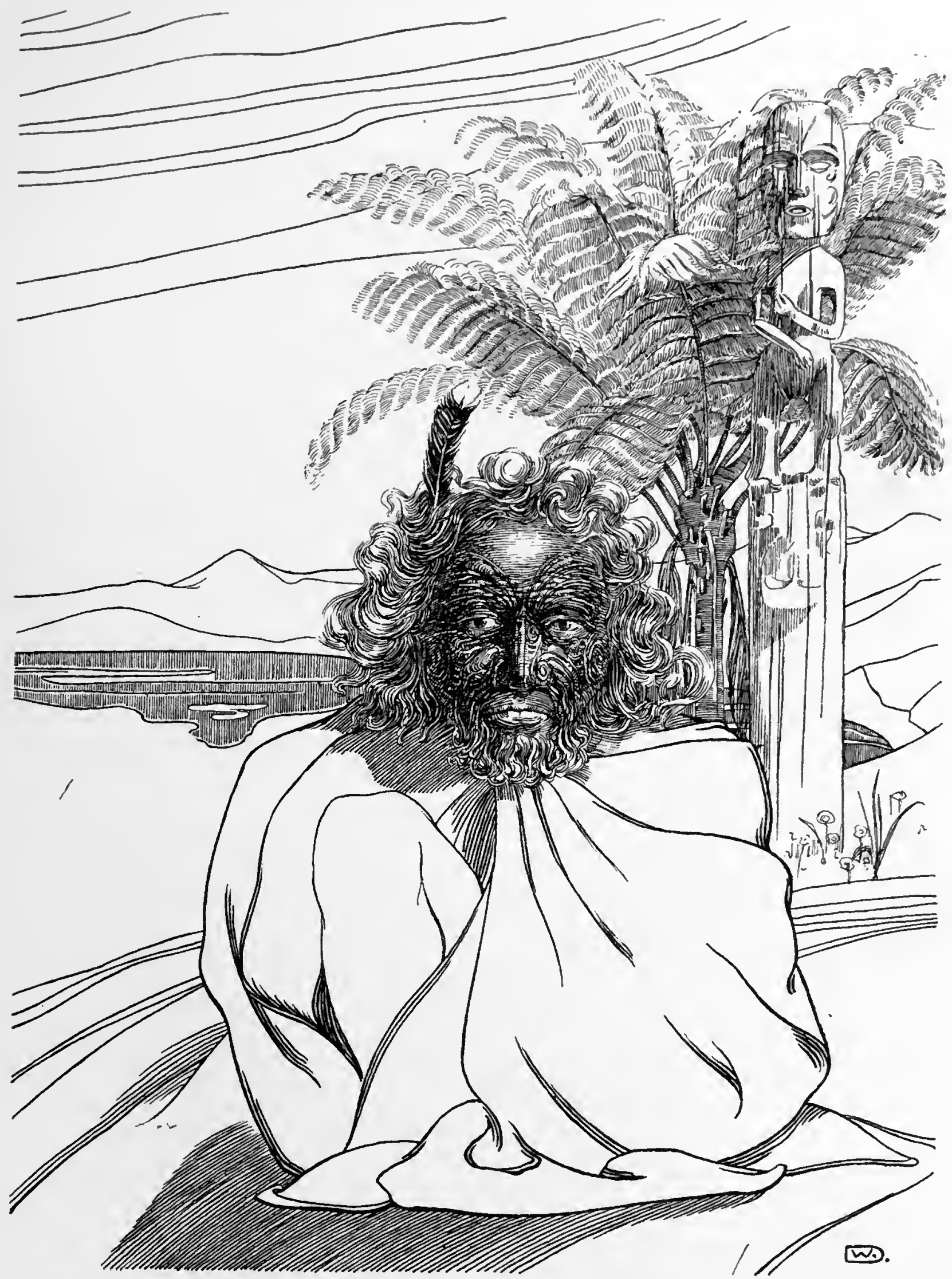





\section{MAUI-THE CREATION OF NEW ZEALAND}
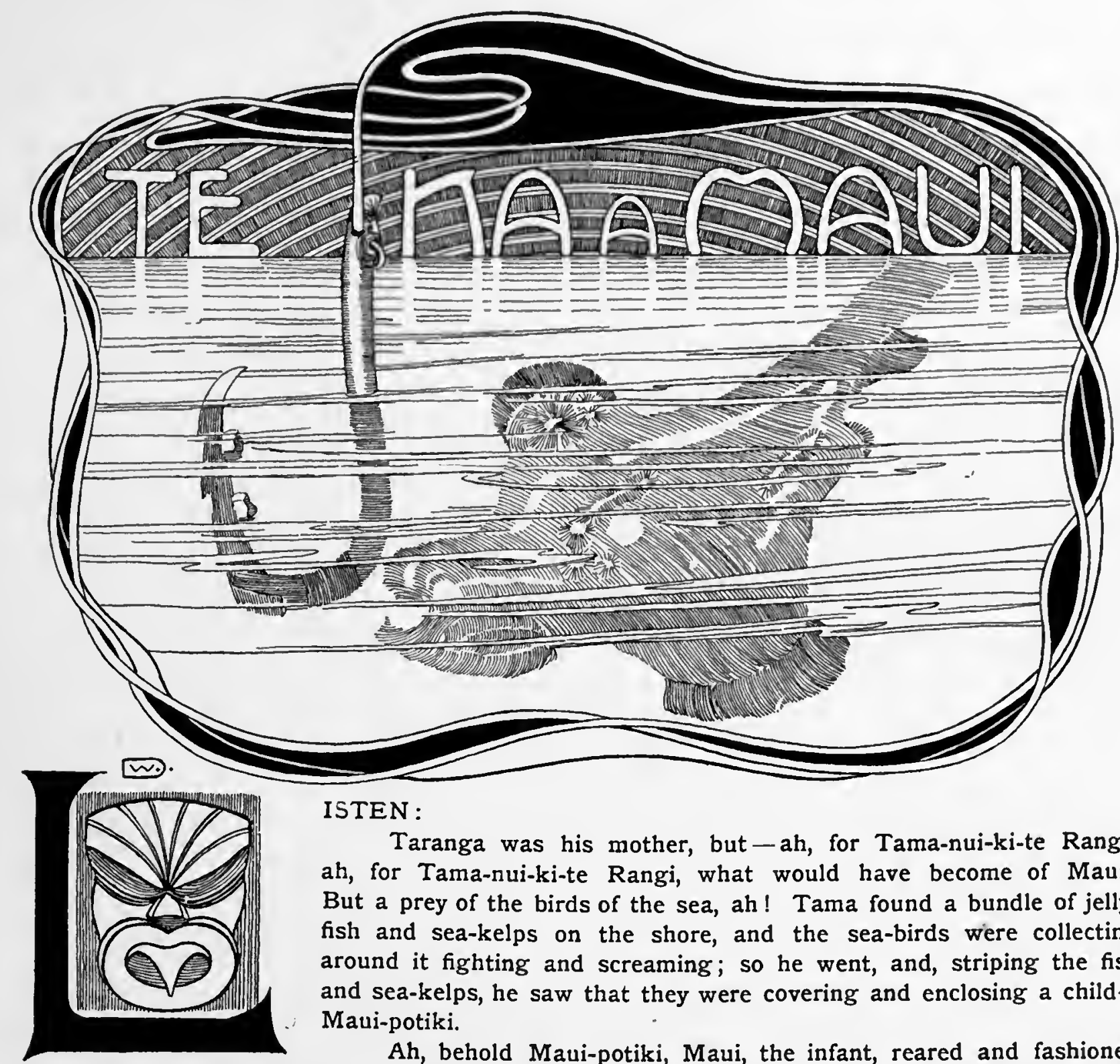

ISTEN :

Taranga was his mother, but-ah, for Tama-nui-ki-te Rangi! ah, for Tama-nui-ki-te Rangi, what would have become of Maui? But a prey of the birds of the sea, ah! Tama found a bundle of jellyfish and sea-kelps on the shore, and the sea-birds were collecting around it fighting and screaming; so he went, and, striping the fish and sea-kelps, he saw that they were covering and enclosing a childMaui-potiki.

Ah, behold Maui-potiki, Maui, the infant, reared and fashioned by the fish and the weeds and the waves, by storms and gales of the rolling sea-ah, but for Tama-nui-ki-te Rangi, what would have become of Maui, alone on the shore? What but a prey of the sea-birds?

Maui-potiki!

Ah, Listen :

Before his time Maui was born, and Taranga, his mother, who gave birth to him on the border of the sea, knew that he could not live; therefore she cut her hair, and, wrapping it around him, she threw him into the surf of the sea-ah. She sang many incantations which have power over the evil spirits; for know, my listener, they are watching for the children who are born to life, before their life is ripe. They try to enter the body and fill the departing spirit of the child with hatred for man-for the departing spirit will never know and receive the joys of man; and therefore, friend, the dead-born children form the multitude of evil spirits.

Ah, great were Taranga's incantations, but what would have become of Maui but for the love of Tangaroa? Tangaroa, the god of the oceans! His are the waves, and they rolled and rocked the child to sleep, and they fashioned him and gave him strength; and they took 


\section{ANCIENT LEGENDS OF THE MAORIS}

possession of him and gave him the power of the sea and the wisdom of the sea - their great incantations which unite heaven and earth; and they gave him the terrible witchcraft of the sea.

Then, rolling him gently on the sand of the beach, the jellyfish robed him, and the seaweeds-ah, my listener!

Tama-nui-ki-te Rangi became his father, and he lived with him till he grew into manhood. Many were his deeds, and great was his cunning: he learned powerful incantations, and he learned how to take the shape of the birds.

At last a great longing for his parents and his brothers grew in his heart, and he set out to seek them, for his heart was longing for them. He wandered and wandered toward the Edge of the Ascending Sun, and many days more he wandered, till he came to the great whare-puni; and all the people were there, and full of enjoyment and happiness.

He saw a woman who was counting her sons:

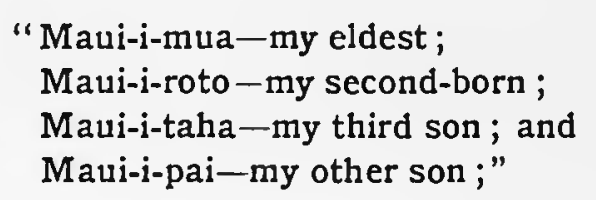

and, perceiving Maui-potiki, she demanded: "Whom do I see among my children?"

Maui, assuming before her eyes the form of a pigeon, flew upon the forehead of Rangi, whose carved image supported the house, and, sitting there, he spoke: "If you are Taranga, my mother, then know, that I am Maui-potiki, your youngest son."

$\mathrm{Ha}$ ! great was the wisdom given him by Tangaroa, and great was his beauty and strength, fashioned by the storms of the sea, so that, when he took the form of man again, his mother saw his great teauty and she believed in him, and knew that he was her son; and she spoke:

"Do you come from the North?"; and Maui answered: "No."

And again she asked: "Do you come from the South?" Maui again answered: "No."

And she asked again: "Do you come from the West ?" Maui again answered: "No."

And she spoke again: "Do you come from the East?"-and again Maui answered: "No."

She said: "Do you come on the waves of the sea?"-and Maui spoke: "The waves of the sea rolled me."

And she said: "Do you come on the waves of the wind?"- and Maui said "Yes!"

Then Taranga cried: "It is true! He is the youngest son to whom I gave birth, and cast his body into the sea because his life was not ripe. He is here again; he is alive; it is true, it is true, it is true! He is my son; he is Maui-i-tiki-tiki-a-taranga!"

Ah, listen, my friend to Maui; Maui, my ancestor!

Three times he slept in the house of his mother, but every morning when he awoke he found his mother had disappeared before day-break.

The next night, when Taranga had come again to sleep with her sons, he waited till all were asleep, and then he closed every hole and rent through which light could come into the house, and put away Taranga's feather-garment and belt, that she might not be able to go away again. In the darkness now Taranga slept till the Sun was standing high, and she cried and searched for her garment and belt. Not finding them she covered herself with an old mat, and ran to a tuft of reeds which grew near the house, and disappeared beneath it.

Maui followed her, and, lifting the tuft, he found that it covered the entrance to a cave.

Quickly now he changed himself into a pigeon, and, binding the white belt of his mother around his neck and her black feather-garment before his breast, he flew to the entrance of the cave, and, entering it, he flew and flew and flew through the long and dark cave till he saw at last the people of another world. Thither he flew, and rested upon a large tree. Sitting there, he perceived 


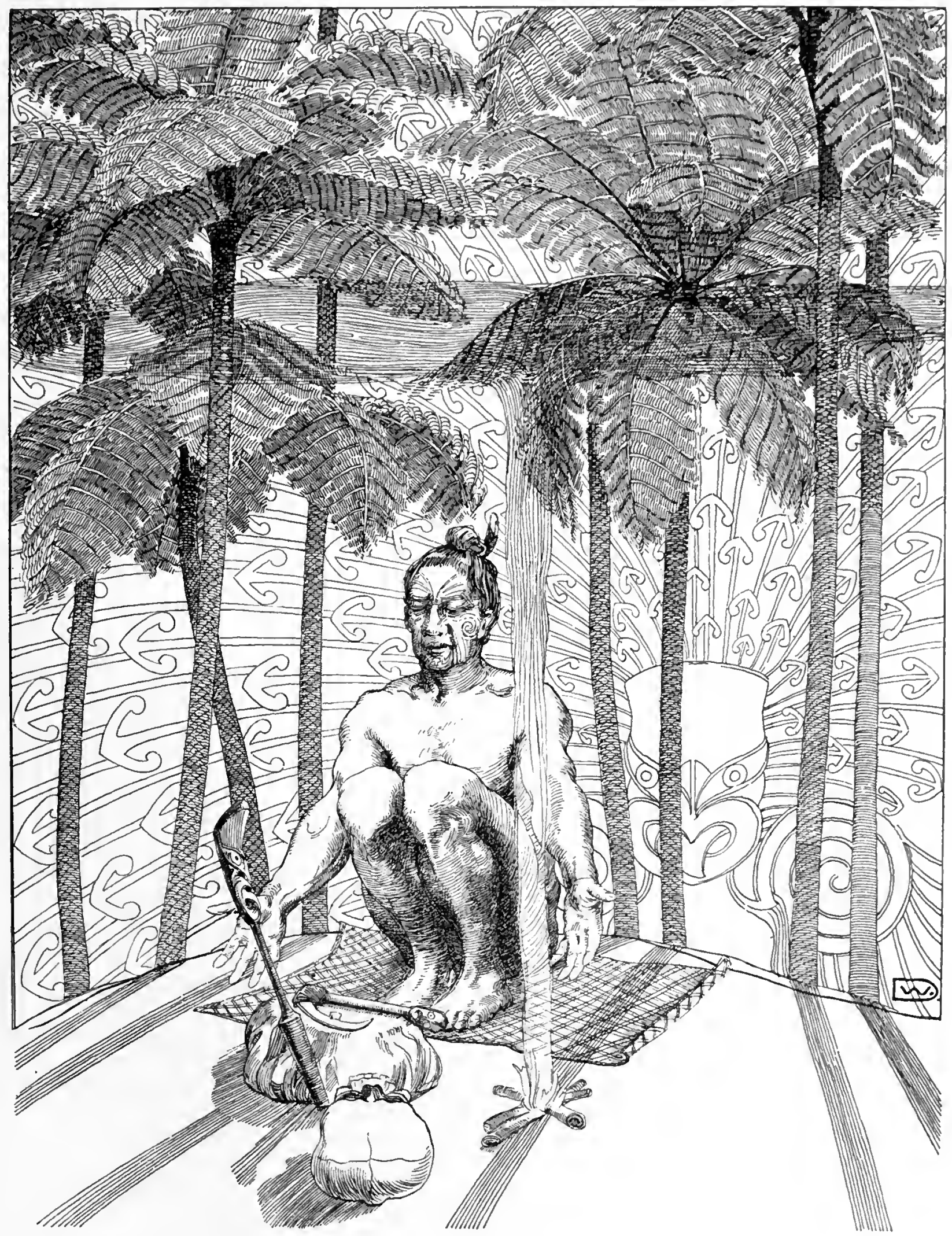





\section{MAUI-THE CREATION OF NEW ZEALAND}

that his mother and father were among the people, and he threw down two berries, hitting both, his mother and Makea-tu-tara his father. They thought the berries had fallen from the tree, and took no heed; but Maui threw and hit them again, and then again. At last all saw the pigeon, and they began to throw stones, to kill it; but they could not hit Maui until at length he wanted them to, and then he fluttered down to the feet of his father. The people now sprang forward to kill the pigeon, but Maui quickly changed into a man again, so that they were struck with fear, and looked frightened into his staring red eyes: they were as red as if they were painted with kokowai.

Ah, my listener, Taranga, seeing her son, chanted the great Song of Welcome of the people of Hawaiki; and then, staring far into the distance, she sang the incantations to the gods who record the past, and with their help she narrated to the people all that had taken place since Maui's birth, and the people wondered, and believed that Maui was Taranga's son-Maui-i-tiki-tiki-ataranga.

And from that time, Maui lived with his people for time, and time, and time.

At last, Maui, full of knowledge and cunning, wished for a weapon, so that he might perform great deeds that no other men could do. He wished for a sacred weapon, and he held many Karakias to the gods whose abode is the tools of the warrior.

One day he asked the people who brought food every day to Muri-Rangi-whenua, his grandfather, and said: "Give me the food that I may take it to Muri-Rangi-whenua, for is he not a sacred man?" And they gave it to him, and he carried it away; but did not give it to his ancestor. Many were the days that passed since he took the food away; but he did not give it to the old man, whose cries became louder and louder, for he was very old and hungry.

At last the spirit of his life took his abode in the jawbone, and, departing from there to be swallowed by Hine-nui-te-po, he left the jawbone - as his last resting-place, tapu (sacred) behind him.

Ah, behold now, my stranger, how, taking the sacred jawbone of Muri-Rangi-whenua, he became the possessor of his powerful weapon. And truly wonderful deeds did he perform with his sacred weapon. Is not all this land its prey-this land, Te-ika-a-Maui? Look how he wanders till he reaches a place on the river at Hawaiki-look how he does not touch any food-look how he distributes the great tapu over the place, how he makes it sacred to the most powerful gods only, and-look, ah, look how he forms the jawbone of Muri-Rangiwhenua into a beautiful fish-hook; how he adorns it with carvings, and how its eyes of pawashell, flash fire into the world! Ha, look, my friend, how he, with great cunning, fashions the teeth into barbs! Ah, see him giving to his weapon the great name of his ancestor, Muri-Rangi-whenua.

$\mathrm{Ha}$, now he held the great Karakia over his fish-hook, making it sacred as an abode for the mightiest gods; and, hiding it in his belt, he went back to his brothers, and he watched them trying to catch fish; but could never land them, for their hooks had no barbs. He said laughingly: "O, brothers, let us together go upon the sea to find out who may catch the largest fish."

But his brothers were afraid of Maui and his cunning and witchcraft: they did not like him in the canoe, and therefore they left so early next morning that Maui had to stay behind.

When Maui awoke and found his brothers gone, he laughed, and changed himself into the little bird, Ti-waka-waka, and flew out upon the sea. When he had reached the canoe he set himself upon the prow, and began to twitter and sing.

Then his brothers knew him, and cried: "It is Maui, oh, it is Maui, who has come!" - and Maui, flying around the canoe, twittered: "Yes, brothers, it is Maui, it is Maui, who has come, Maui, Maui!" Then, throwing off all his feathers one by one, he took the form of man again, and spoke: " $\mathrm{Ha}$, my brothers, now you shall see how Maui catches his large fish, and you shall not know its name! But let us go further out upon the sea-there, 


\section{ANCIENT LEGENDS OF THE MAORIS}

where the sea is deep, there is Maui's fishing-ground." His brothers now paddled and paddled, till at last they said: "Truly Maui, this must be your fishing-ground, for we can see Hawaiki no more." But Maui answered: "No, no,-let us go further out-where there is no more end to the sea."

At last they came to a place in the middle of the ocean, and Maui spoke: "Eh-hu, my brothers, this is Maui's fishing-ground, the great battle-field for his fish-hook, Muri-Rangiwhenua."

Now he took his fish-hook with great care, so that his brothers might not see the barbs, and asked them to give him some of their bait; but they laughed, and cried: "No, no; mighty Maui, show us your big fish, the fish we do not know - the fish you catch without bait ! - ho, ho, the great fish of Maui!"

$\mathrm{Ha}$, ha, my friend.

But now, in great rage, Maui tore half his hair out, and, soaking it with his blood, he baited his hook with it. Then he threw his line far, far out into the sea, and began to chant this great incantation:

\footnotetext{
"Blow gently from the wakarua,

, Blow gently from the mawaki

My line, let it pull straight,

My line, let it pull strong ;

It has caught,

It has come.

The land is gained.

The fish is in the hand -

The fish long waited for,

The boast of Maui,

His great haul,

For which he went to sea,

His boast, it is caught!"
}

Ha, see how his fish has swallowed the hook! Ha, see how his line straightens; see how Maui pulls and pulls with all his mighty strength! See, how his strength presses the canoe under water! $\mathrm{Ha}$, listen how his brothers cry and wail; ha, ha, listen! "Maui, Maui, let go; let your fish go; oh, let go, let go, Maui!" Ha, ha, see how Maui pulls; and pulls, and pulls; see him pulling for three moons! Ha, listen how he shouts to his brothers: "What Maui has got in his hands he cannot let go again!"

Hearken now to his incantations to the gods who make heavy things light-ah, see him gathering together all his mighty strength, ah, see him pull, see him pull! Ah, friend, the sea foams, the sea thunders, the sea storms-ha, oh see, ah-ha, behold the fish of Maui, Maui's fish swimming upon the surface of the sea-Maui's fish-Ha, friend, it is this land! It is Te-ika-a-Maui. - Aotea-roa, this land. - Ah, behold the wisdom of my ancestors: how Maui's hook caught the house of the old Tonga-nui on the top of Tongariro, and pulled all this beautiful land out of the sea, Te-ika-a-Maui.

"Open now your throats that are still hoarse and tired from crying, my brothers, and tell me the name of my fish": so spoke Maui boastingly; but they could not give the name of the fish, and Maui said full of pride: "It is Te-ika-a-Maui!"

The canoe was now lying on the mountains at Hiku rangi, and Maui's brothers took their weapons and sprang forth, and wounded and killed the fish, and, ah, my friend, from that time are the hills and the valleys and the mountains: they are the foot-prints of the brothers who did not follow Maui's bidding that they should wait till he had made offering to the gods that they might regard his catch with favour, and that his fish might retain its beautiful smooth surface for ever. 


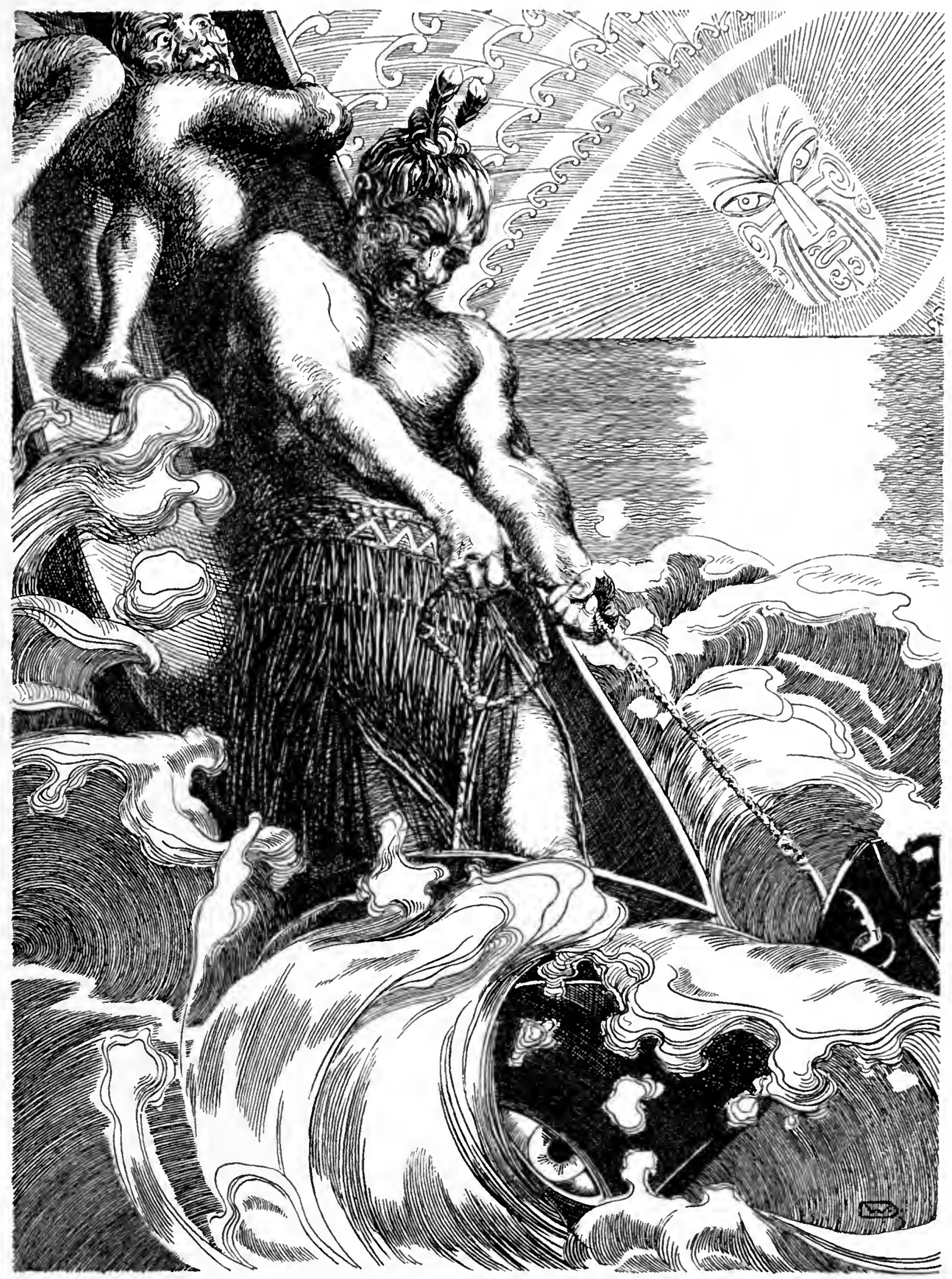





\section{MAUI-THE CREATION OF NEW ZEALAND}

No, they did not follow Maui's advice. Maui, our ancestor-Ah— (murmuring very low): Maui-i-tiki-tiki-a-Taranga

Ah,_- (and lower stllI): Angi, angi ki te wakarua-Angi, angi ki-te-ma-wa-ki-Tuku aho-to-

Respect demands sleep.

Tapu is the sleep of the very aged.

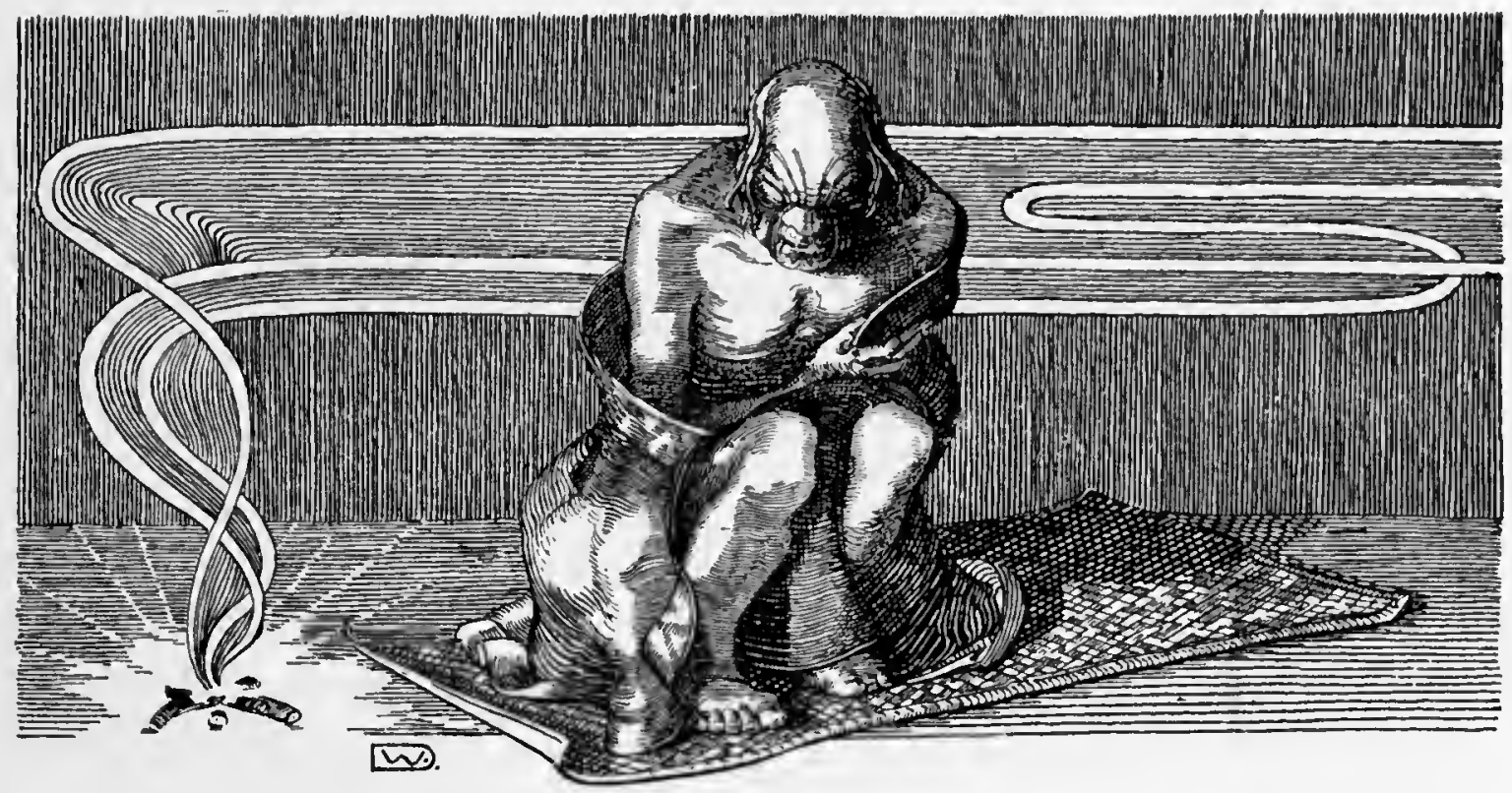




\section{MAHUIKA}

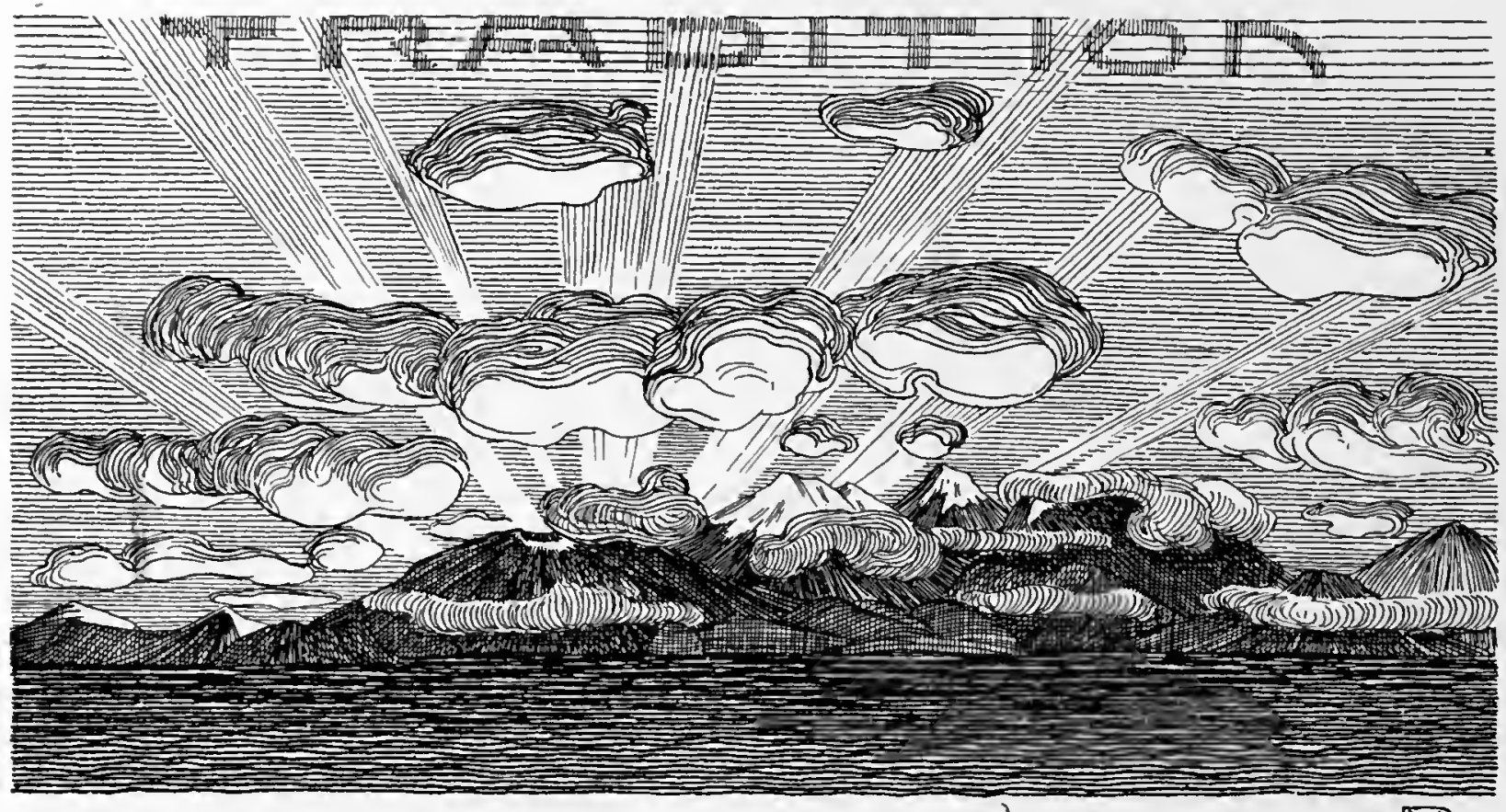

Ш一⿻

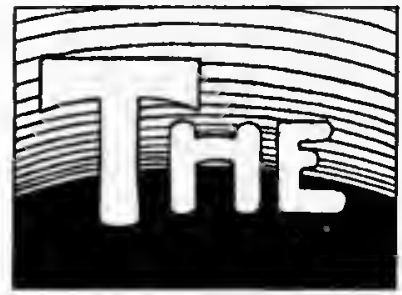

GODS and the heroes of the Maori people are personifications of Nature and her elemental powers: through the forms and doings of these gods and heroes alone could they understand Nature-night and light, cloud and lightning, sun and ocean.

The personalities and deeds of these heroes were human translations of the unfathomable workings of Nature and the character of the elements : the winter became the mother of the summer, but the winter has to devour his child again; the night kills the evening, but the morning kills the night through its fire. The moon is slowly eaten by her enemies, and must descend to the dead that she may be born anew out of the world of death; the gods of the lower world devour the dead that they may be cleaned and come to life again in the Reinga. The sun alone is wandering daily through the heavens, and nightly through the world of darkness, with never diminished brilliancy; and this phantasy gave birth to the Sun-god Maui, the great hero of the Maori people.

Taranga, the goddess of the Night-sun, is his mother, but Tama-nui-ki-te-Rangi, Great Son of Heaven, lifts him as a child, Maui-potiki, out of the ocean upon which he is swimming, and rears him into manhood. With him Maui learns to use his great wisdom, given to him by the sea-his Sun-wisdom. He learns how to assume the form of birds, to throw spears, to cast fishing lines, for birds, spears, fishing-lines, are the wisdom of the sun-rays.

Grown into manhood, and in full possession of his Sun-wisdom, he wanders forth to find his brothers, the heroes of the Ascending Sun, the Sun at midday, the evening Sun, and his mother, the Night-Sun.

His mother recognises him as her son whom she had given birth, and had thrown into the sea, and she takes him into her house; through cunning he follows his motherwho only lives with her children during the night-as pigeon; bird-sunrays, through the caves of the lower world to Hawaiki. Here he throws his berries (sunrays) upon his father and 
TARANGA AND MAUI

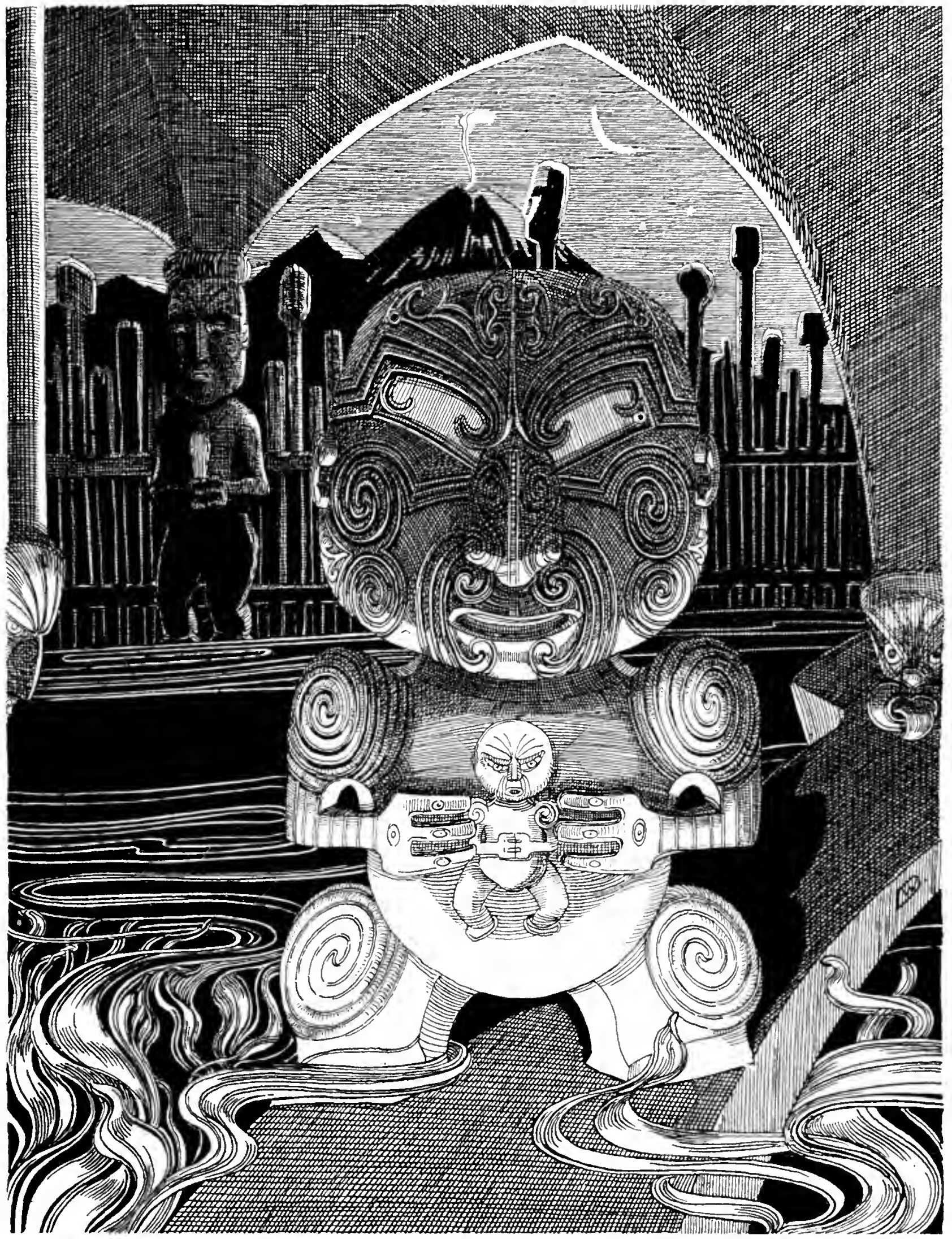





\section{MAHUIKA}

the people and is again recognised by his mother and received with songs of welcome by her and with incantations by his father to make him all-powerful, in the world into which he has now entered as the first Sun-rise.

But after a time he extinguishes all the fires of the world, and enters the Lower World to steal new fire from his ancestress Mahuika.

Mahuika is the mother of the fire, and her children, living in her fingers are the first rays of light which shoot over the sky in the mornings. In order to ask for one of her fingers he visits Mahuika, but he deceives her, and she, to punish him, sets fire to the world. Out of this fire-the second Sunrise-emerges the flying Maui, flying as sun-eagle over the heavens, and hurling himself at last into the ocean.

That was the first sunset. 


\section{MAUI AND MAHUIKA}

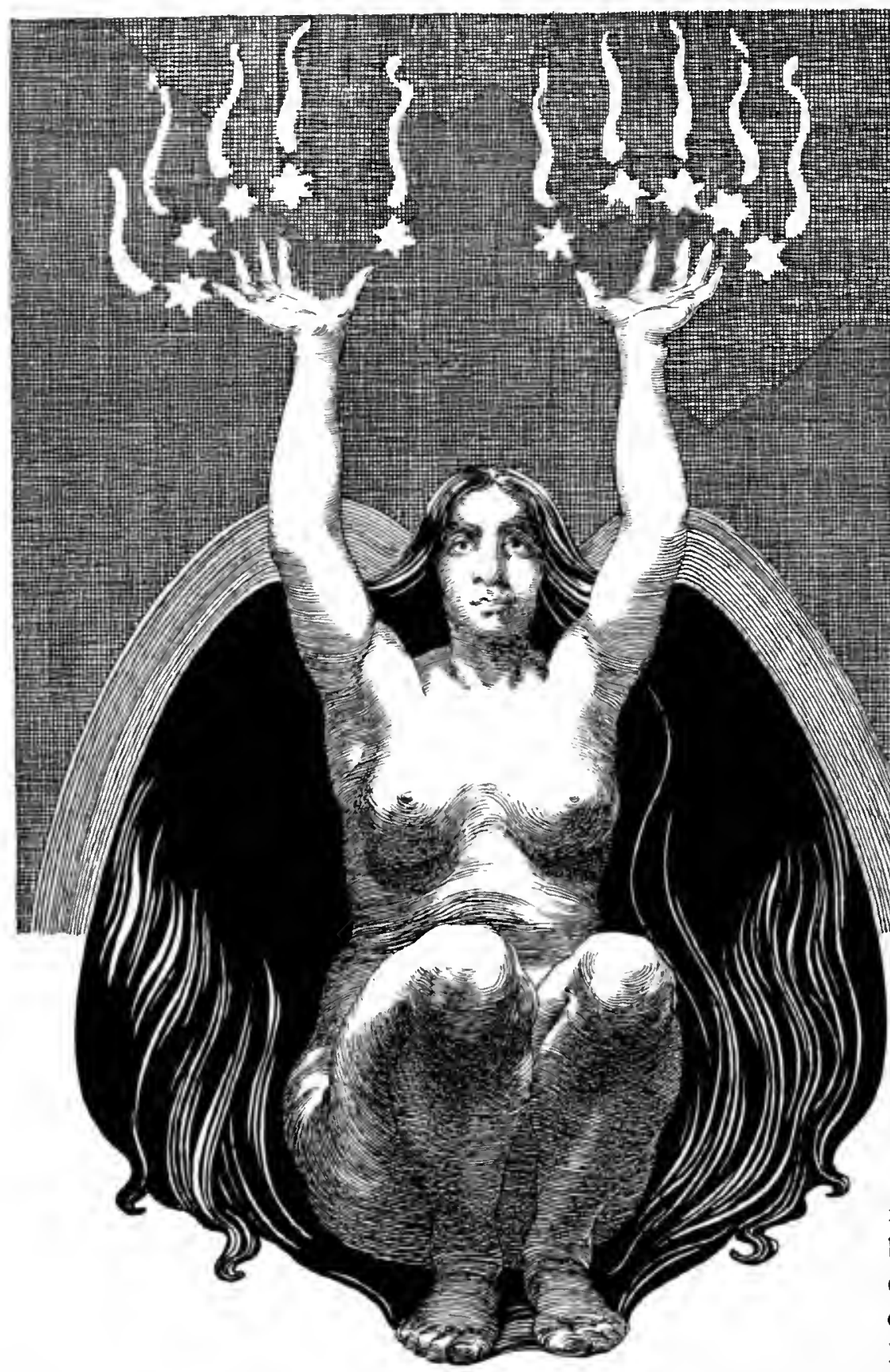

s'aves to cook his food?' And all people were awakened by his noise, and they found all fires extinguished at Hawaiki.

Ah.-

The ancestress of Maui, my listener, Mahuika, was now alone in all the world in the possession of fire, for she is the mother of fire, which is living in her finger. She was to be found at her great dwelling-place in the Lower World, but it was terrible to go near her; and fear entered into the hearts of the people of Hawaiki, for who could go near her in her terrible beauty? Ha! Maui alone, the great hero-ah, Maui, my tupuna! (ancestor).-Oh listen, my wanderer-Maui alone had the courage to go to Mahuika to ask her for one of her fingers! He wandered through the caves of the Lower World, and nearer and nearer he 


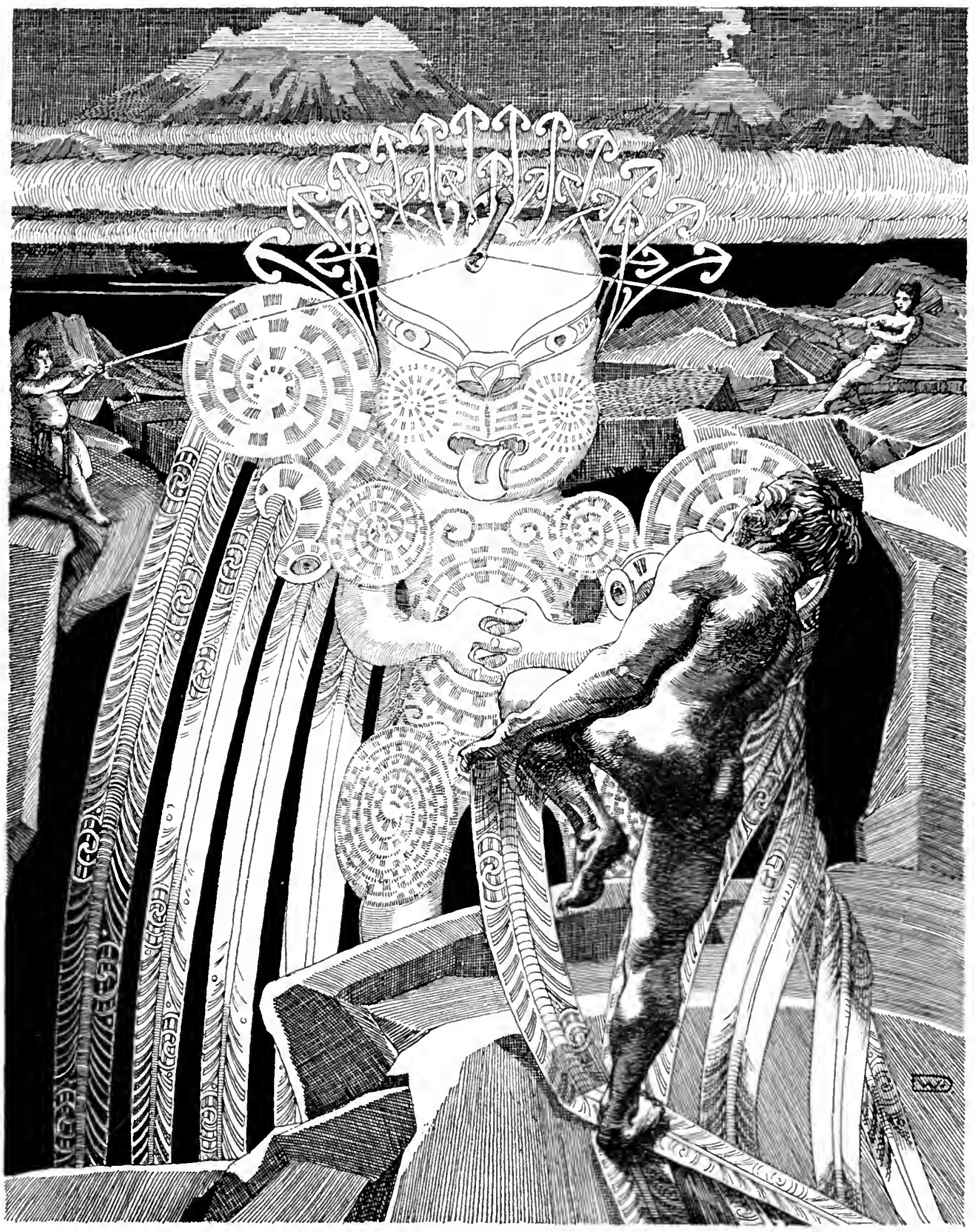





\section{MAUI AND MAHUIKA}

approached Mahuika, his heart full of courage and cunning; but, ha, when his eyes beheld his ancestress, he began to tremble so that he could not speak-ah, friend, Mahuika was beautiful to look upon in her dark cave surrounded by her children, who shone forth out of the darkness. At last Maui overcame his fear and he spoke: "Oh, old woman, Mahuika, will you give me some of your fire?"

Mahuika, surrounded by fire, was terrible to behold - ah, my listener, terrible. She cried : "Au-eh, who is there in the light of my children?"-and Maui answered: "It is Maui, your grandson." Mahuika now asked him the four sacred questions, and he answered them as he had answered Taranga, when Mahuika knew that her grandchild was standing before her in the light of her fire, and she spoke: "Yes, my son, I will that you receive the fire you have asked for"- and she took one of her fingers and gave it to Maui.

With the fire he now wandered back, but, when he had travelled part of his way, his old cunning overmastered him, and he resolved to take all the fire of Mahuika. Ha, ha!

He killed the finger Mahuika had given him in a great water, and went back to his ancestress to ask for another finger, telling her that he had lost the first one.

And Mahuika gave him another finger-ha, ha.

He killed the second finger, too, in the great water, and came back to ask for more; and his ancestress gave him another finger-ha, ha-ah! Maui came again and again, and Mahuika gave him all her fingers till she had only one left-ha, ha! Maui killed them all in the great water; but, when he again came back and asked for the last finger, then Mahuika knew that he wished to deceive her and kill her, and a frightful anger took hold upon her! Ha, she took her last child, her last finger, and threw it upon the world, and the world filled with fire-ha!

Ah, then Maui began to run!

The flames grew larger and larger, and followed him; he ran into the forests, and the forests caught fire-ah, Maui, my ancestor-ah, he ran into the river, but the river began to boil-ah! He took the form of an eagle, but the flames pursued him high into the air. Ha !-he sang great incantations to Tawhiri-matea and the gods, and they sent clouds of rain. The clouds wandered forth from the end of heaven and burst into rain, and long rain fell upon the fire, and heavy rain, and lasting rain. Through the rain flew Maui, and threw himself into the sea, to save himself from the terrible wrath of his ancestress Mahuika-ah!

Ah, my listener, Maui had almost perished through the terrible fire that filled the world, but Mahuika, ah, Mahuika, she had to perish in the endless floods which fell down upon the world. She knew that she had to die, and she filled the world with terrible cries. With her great swiftness -for is she not the mother of the fire?-she ran and ran to save her child, the flame; and she ran and ran but the flood of the rain always followed her. At last, knowing that she must die, she took her last child, her last finger, and hid it in the Kai-Komaki tree-and then, my listener, the rain has slain the mother of the fire-ah!

But the Kai-Komaki tree has sheltered up to this day the child of the fire, so that men take its dry wood and rub it together till the flame which once lived in the finger of Mahuika bursts forth to new life again.

You have heard how Maui cheated his ancestress Mahuika, and nearly perished in the flames. Listen now to the song of his great strength and braveness, that you may know how he once fought and conquered Te Ra, the Sun, himself.

These are my words:

They were the days when our ancestors were still living at Tawhiti-nui, the Great Distance.

The days were short, and $\mathrm{Te} \mathrm{Ra}$, the $\mathrm{Sun}$, wandered through the heavens and through the Lower World; but the days became shorter and shorter, and faster and faster wandered the Sun through the heavens.

Ah, the nights grew longer and longer, and in the long nights grew the longing for longer 


\section{ANCIENT LEGENDS OF THE MAORIS}

days in the heart of Maui, and out of the longing was born his great cunning plan to fight the Sun and to compel him to create longer days.

Ah, listen how he persuades his brothers in Tawhiti-nui to aid him in his work! Frightened were his brothers at first, but, when he showed them his art of making sacred ropes out of the long hair of women, and of forming the ropes into nooses, then the hearts of the brothers lost their fear, and they began to burn with eagerness for the fight.

Yes, Maui taught his brothers the art of making ropes, and from him descended his wisdom to my people.

At last, my listener, all ropes and nooses were ready, and the brothers burdened themselves with them, and they together started on their distant journey.

Maui took his sacred fish-hook, Muri-Rangi-whenua, the End of Heaven and Land, and showed his brothers the way. They wandered by night, and, as soon as the sacred red broke forth at Mahiku-rangi, they hid themselves under the rocks, that $\mathrm{Te} \mathrm{Ra}$ might not see them. And again they wandered forth by night till they had wandered many, many nights; and they at last reached the cliffs of the caves out of which $\mathrm{Te} \mathrm{Ra}$ ascended in the mornings.

$\mathrm{Ha}$, here they looked for shelter, and Maui warned his brothers not to expose themselves to the arrows of the Sun, that they might not be killed in the battle.

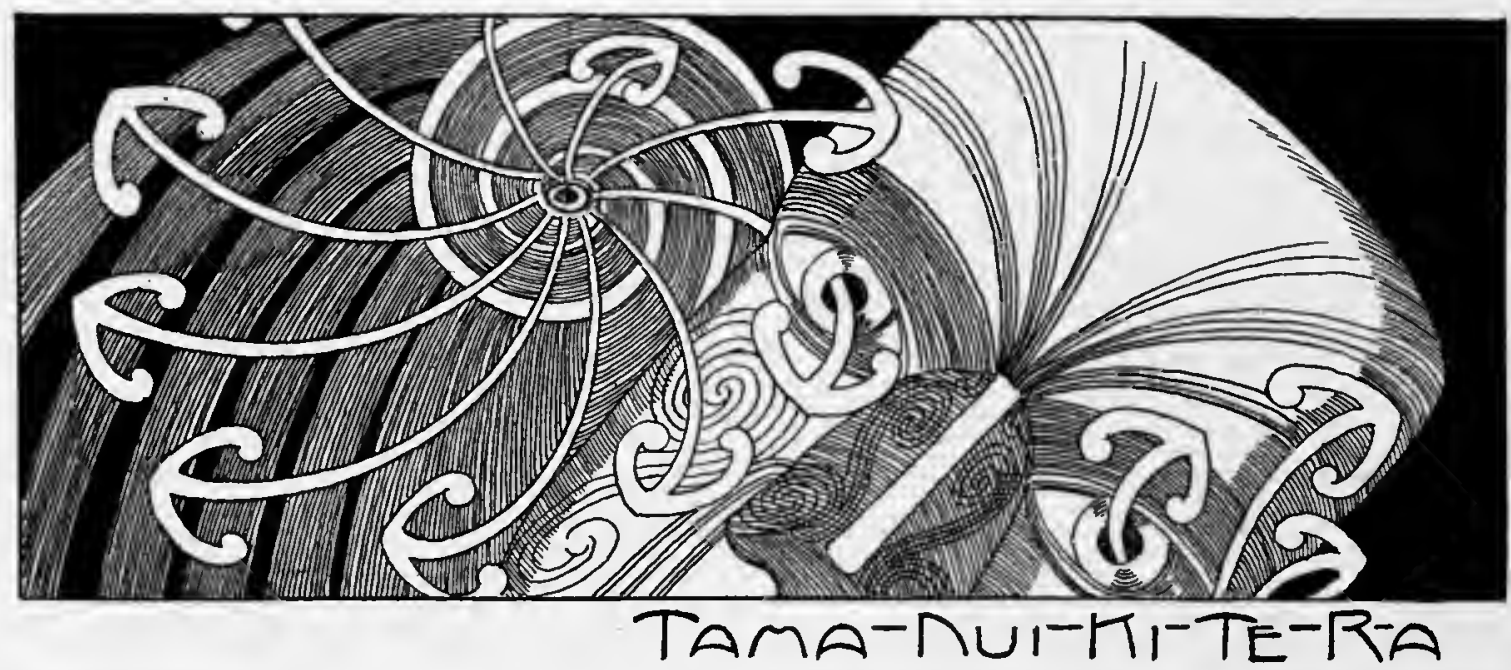

Ah, Maui, the hero, he spoke to his brothers till all fear had left their hearts, and the desire filled them to fall upon their enemy; and then Maui showed them how they could catch $\mathrm{Te} \mathrm{Ra}$ in their ropes; and he showed them how to hold the ropes-tight, tight, and tight, so that the Sun would be powerless and he could kill him with his sacred weapon.

$\mathrm{Ha}$, let the eyes of your mind perceive how $\mathrm{Te} \mathrm{Ra}$ ascends out of the Lower World-see how he slowly appears in the precipice; see, oh see, how he entangles himself in the strong ropes how the brothers throw the nooses-Look, ah, the Sun is caught!

$\mathrm{Ha}$, the brothers hold; they hold tight. Oh, see Maui!-Maui springs forward with his sacred weapon-Te Ra cries!-Ah, Maui beats him; look, he bleeds!-ha, again he beats the Sun; again-again-Te Ra cries wildly!-ah, ah-Maui has broken his wing-O Maui, the hero!$\mathrm{Ha}$, that is a terrible battle! Oh, see the eyes on Maui's fish-hook flashing light-see the carvings; ha, see the adornment of sacred dog's-hair-Ah, his weapon is superbly beautiful! Ha, did you see the arrows of the Sun? Do you see the flashing of his arrows?-Ha, Maui, the brave !-Now, the Sun cries!-friend, she trembles!-she tears-she pulls!-Her blood is covering the whole East of the heaven!-Ha, Maui-Maui_-my ancestor! Ha, oh- ha, Te Ra has torn himself free! $\mathrm{Ha}$, beaten by his enemies, bleeding from terrible wounds, with broken wings, with cries of pain he goes his way-slowly-slowly-Oh, Maui!- 


\section{MAUI AND MAHUIKA}

Can you hear Te Ra wailing? Ah, he cries!-What is he crying? Ah, he cries: "Ah, why has man wounded me so terribly? -ah man, do you know that you have wounded Tama-nui-kite-Ra? Why would you kill Tama-nui-ki-te-Ra?"

Ah, my listener-

That was the first time that the great name of the Sun was made known in HawaikiTama-nui-ki-te Ra!-

When Maui heard that great name, his heart glowed in pride, for he knew then that he had fought the greatest battle a hero can fight, that he had conquered the Great Son of the Heaven.

From that time the Sun went slowly over the heavens, so that the days became long again and full of happiness for the people at Hawaiki.

Go, my friend, and remember the words of the old man who is your friend! 


\section{$\mathrm{XI}$}

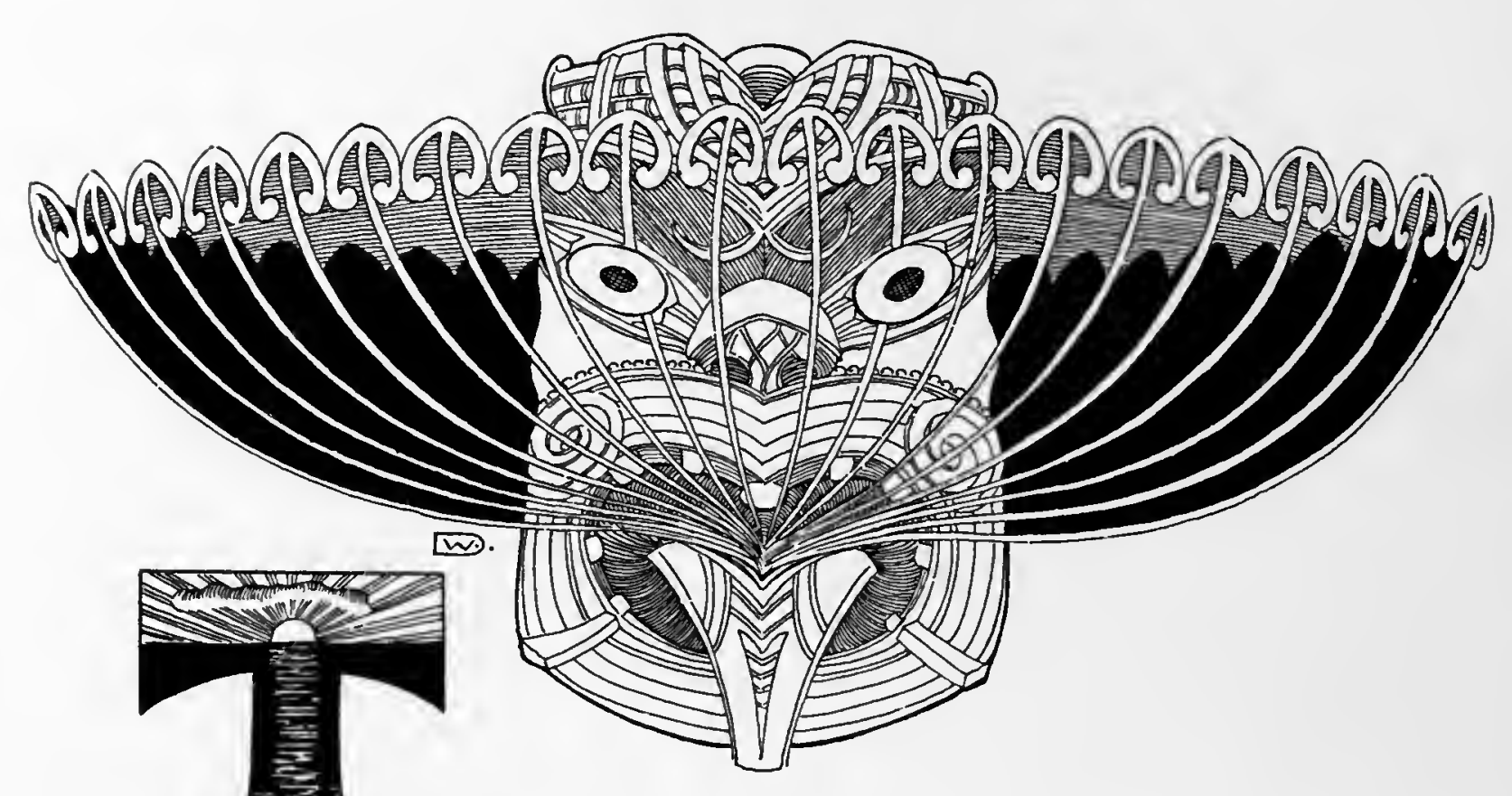

HE DEATH OF MAUI

Many descendants had Maui; and many of them were living at Hawaiki, and many were living in this land, in Aotea-roa. When he had created this land; when through his great deed he had compelled Tama-nui-ki-te-ra to prolong the days that the hearts of his descendants may be gladdened; and when at last he had cheated Mahuika out of her flames which were living now in the Kamaki-tree to give fire and warmth to his children, then the life at Hawaiki became finer and finer; and finer and finer became the life at Aotea-roa. That was the time when the great wish grew in the heart of Maui, the wish to conquer his powerful enemy Hine-nui-te-po, that Night might die and man may live for ever: ake, ake, ake!-yes, it was his great wish.

At length he wandered to the tree at Hawaiki, and here he found his parents, and told them of his great desire. But his parents were still angry with him about the evil trick he had played on Mahuika, the trick which had nearly cost him his life; but he laughed, and spoke boastingly: "Ho, old people, have I not done greater deeds than this one? Who caught the big fish, Te ika-a-Maui? Who? - Maui! Who captured Tama-nui-ki-te-Ra? Who?-Maui! Truly, old people, Maui will continue on his way for ever and ever! $\mathrm{Ha}$, he will go and kill Hine-nui-te-po! Hine-nui-te-po!-so that the life of man may be for ever and ever: ake, ake, ake! Who is stronger than Maui?"

And his father answered: "Hine-nui-te-po, whom you may behold yonder flashing on the horizon, is stronger than Maui!"

Thereupon laughed Maui, and spoke: "When Hine-nui-te-po can take my life, then you can tell me how her looks are, ha, ha!" But his father spoke warningly: "Ah, my son, her eyes, which you see flashing yonder, are dark as greenstone; her teeth are sharp as obsidian; her mouth is like the mouth of the Baracuta, and the hair of her head is the sea-weed; her body alone has human form!"

But Maui only laughed, and asked: "Is Hine-nui-te-po as strong as Tama-nui-ki-te-Ra? Is her strength as the strength of the sea, which I have conquered and filled with land? Is her power as great as the power of the fire-Ha, ha?" And his father had to answer: "It is well, my youngest son; go brave there where you find your ancestress flashing with fire on the horizon, and conquer her. Go, son of mine!"- 


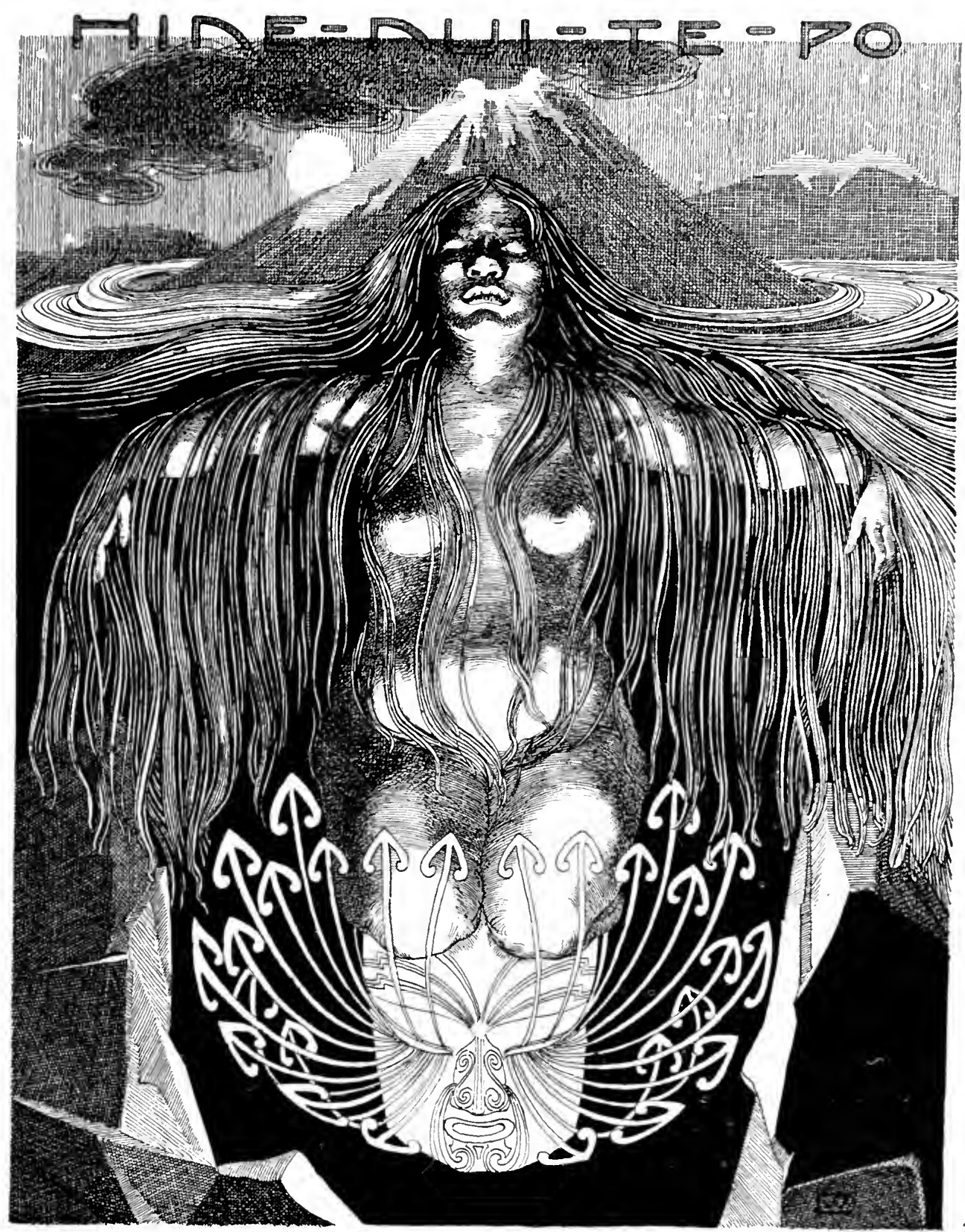

tomy Friend 


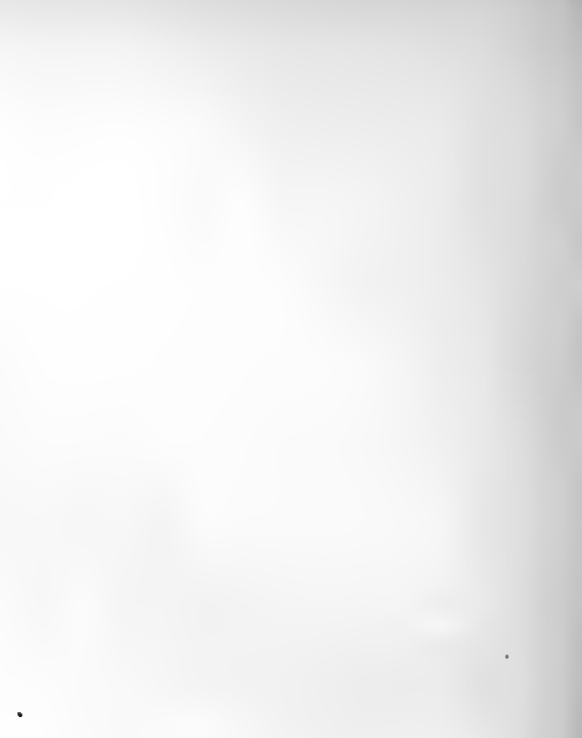




\section{THE DEATH OF MAUI}

Maui now took the shape of a beautiful coloured bird, and flew high up in the sacred tree at Hawaiki, and sang and twittered till all the birds of the forest collected around him: the Tui and the Huia and the Kaka, the little Fantail and the Robin-all the birds followed the sweet call of Maui, and great singing and life and happiness were in the tree at Hawaiki.

When night came Maui and all the birds flew toward the west where Hine-nui-te-po lived, and there they descended and found the old goddess asleep.

Maui now took the form of man again, and prayed the birds to be very careful, and very quiet, and not to laugh, for he was going to undertake his greatest deed: to enter into Hine-nui-te-po and to steal her heart, so that she must die and man might live for ever and ever-ake-ake-ake!

When the little birds heard Maui speaking thus, they fluttered about and chirruped and were full of fear, and they twittered: "Maui, do not do it, do not do it, Maui; no, Maui; no, no; Maui, do not do it!"

But Maui only laughed, and threw off his mat, so that all birds could see his beautiful tattoo, the work of the god of the Rainbow, and, taking his enchanted weapon, he entered the old goddess Hine-nui-te-po. All the while the little birds were flying and fluttering hither and thither and were full of fear for Maui. They fluttered noiselessly through the bushes and higher then up the trees and, looking out of curiously glittering eyes upon Maui, they were happy, beholding the wonderful spectacle of Maui entering Hine-nui-te-po.

Ah, then was it that the little bird Tiwakawaka could not longer be silent, but burst out into a heartfelt twittering laughter. Ah, the sweet noise awoke the old goddess, and opening her greenstone eyes, she saw Maui and his doings. Wrath overcame her, and quickly she snapped her jaws together, biting through Maui and killing him with her sharp teeth of obsidian. Then she took him down into the everlasting darkness.

That was the death of Maui! 


\section{XII}

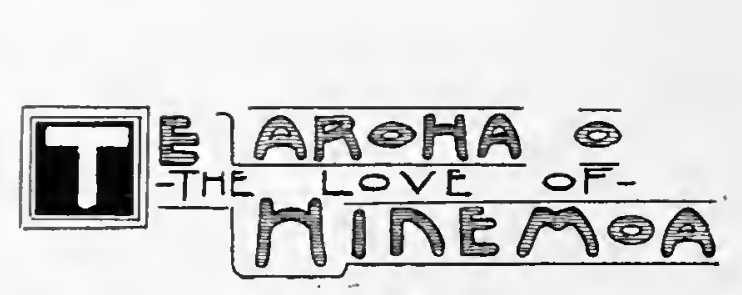

IGH above the sandhills

Rangi the mighty spreads his Garment of Day. It is adorned with a border of snow-white clouds, which is resting on the distant hills of Papa, Papa, the happy.

$A h$, she is sending white cloudmessengers of her love up to Rangi, to Rangi, the smiling, the beloved of Papa.

His golden Eye of Day caresses Papa, and looks down upon her with tenderness, and her blood mounts blushing into her cheeks of snow - white cliffs, and higher into the crimson glory of the flowering Pohutukawa trees which crown the cliffs. The crimson flowers flutter down on the beach, of which Tangaroa, the ${ }^{1}$ unresting, takes possession again with long - rolling lines of froth borne on trans-
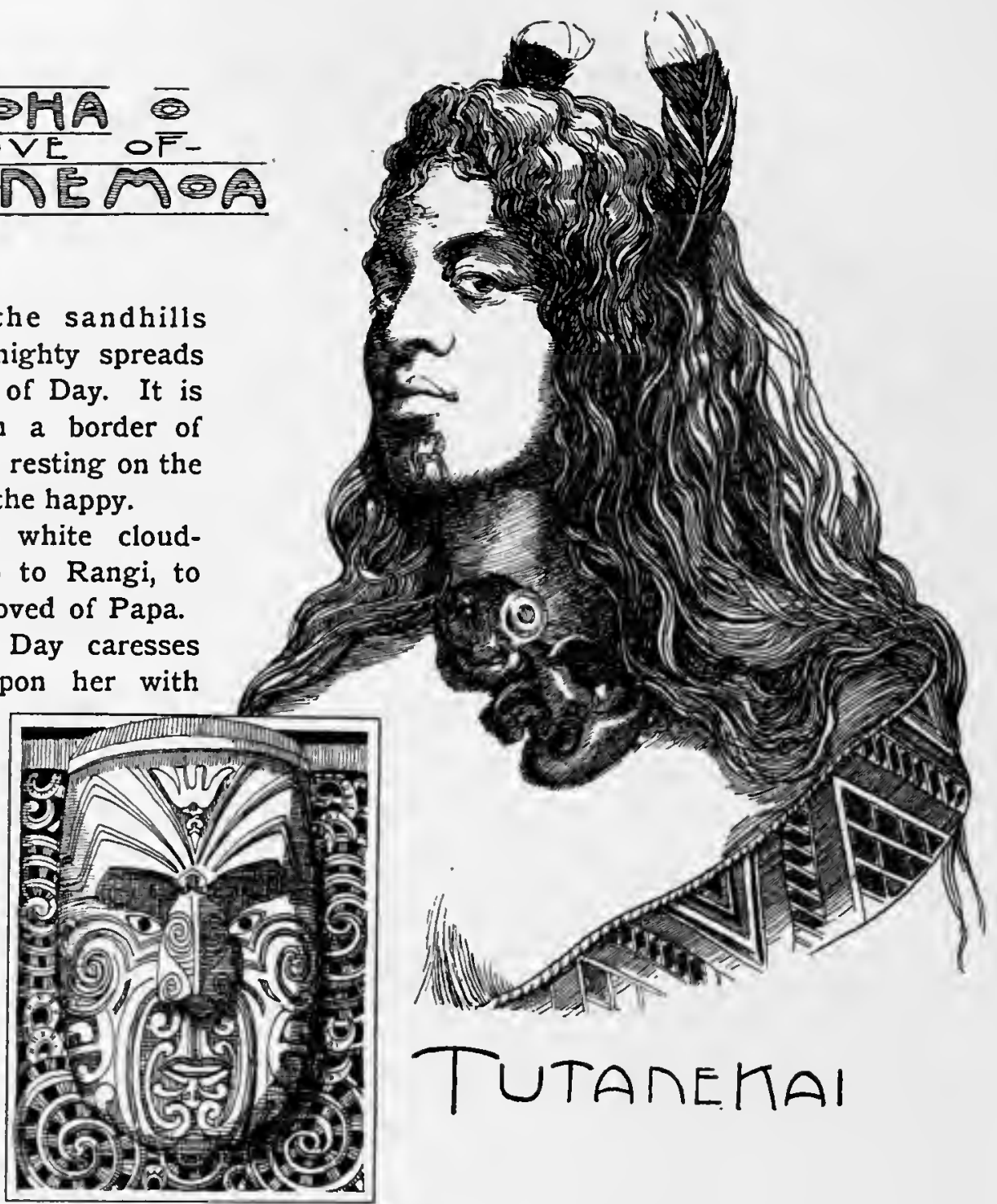
parent waves and thrown ashore with majestic laughter and thundering songs to Papa, the beautiful mother.

"See, how Rangi's Eye of Day looks down, my good friend, filling the heart with longing Ah, longing for happiness enters the heart of man, and Hine-nui-te-po is forgotten."

"Tell me, Ngawai, my good friend, what you have heard of the people who have wandered before us on the path to the Mother of Rest. Tell me what you have heard listening by the fires of the whare."

"Listen then, while we wander along the border of the sea to the love that has been, the love of both, the two, of Hinemoa and Tutanekai."

"The clear waters of the Waitemala never gave back such a beautiful image, nor did the flowing water of the Waikato nor the bottomless depth of Taupo-moana, as did the lake Rotorua on the evenings when the world was calm and Hinemoa looked down into the depths and was full of gladness."

Ngawai commences her narrative while the sun paints a blue halo in the black hair around her head. The light plays in the sunburnt face, the lips quiver, and the large eyes, full of light, see in the distance what the lips utter.

"Oh, Hinemoa was full of gladness and was smiling at her image for joy, for over the sea sweetly sounds the music of the flute and the horn played by Tutanekai and his friend Tiki, far off in the middle of the lake on the island of Mokoia, Tutanekai's home." 
TE AROHA O HINEMOA

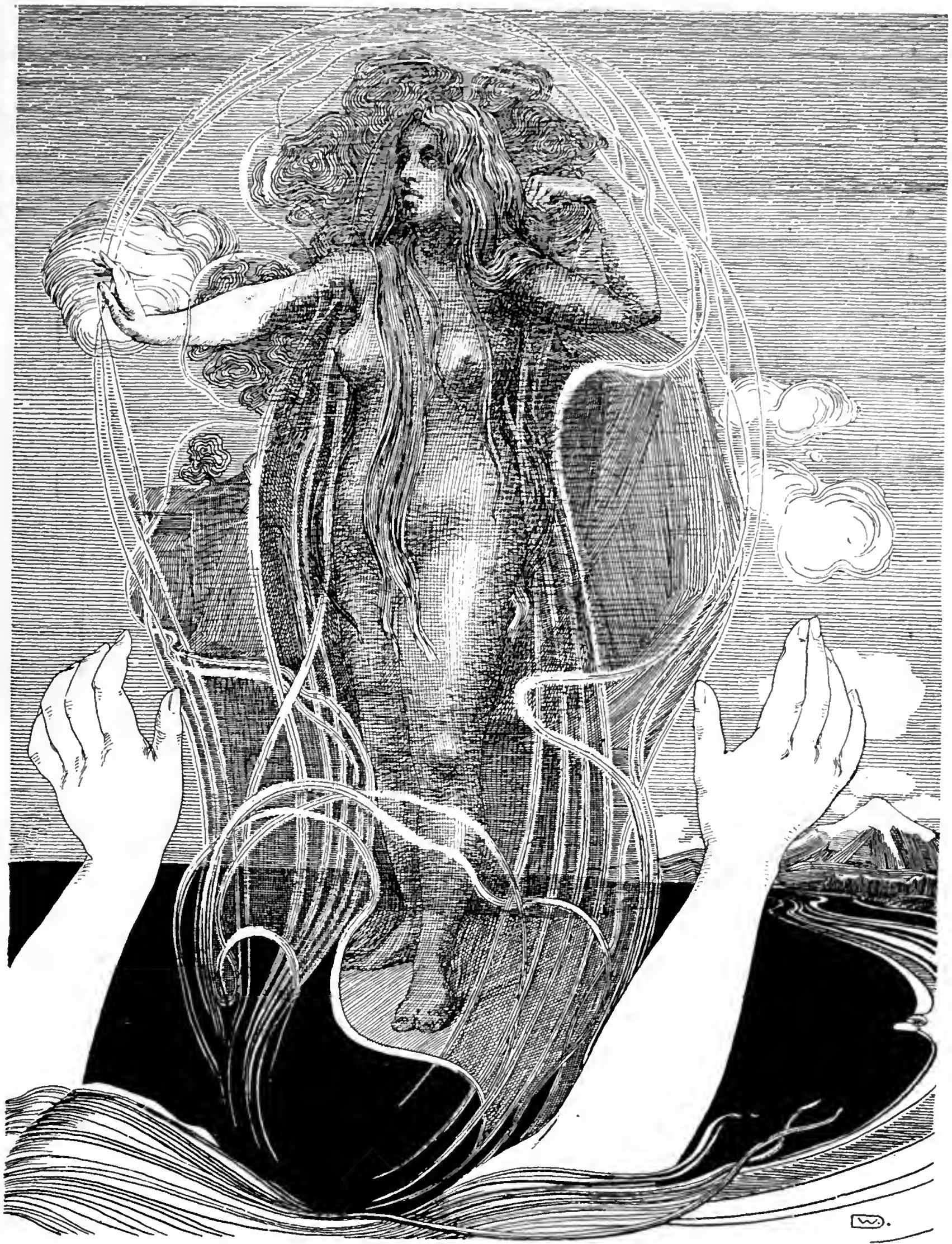




\section{TE AROHA O HINEMOA}

And she sat and listened murmuring to the water: "Oh, Tutanekai, how sweet is thy music to my heart! On many a calm night has Hinemoa listened, and her joy grew always greater, and her heart happier within her. Sometimes there were great gatherings of the people on the mainland, in the pa (village) of Amukaria, Hinemoa's father, and Tutanekai came over, but he felt sorrowful amidst the feasting and frolic. He stole quick glances at the beautiful maiden, but his hand was trembling and he was ashamed; and he glanced over where Hinemoa was sitting like a beautiful white heron among a flock of Kiwi, and his heart was frightened. He was frightened and ill, and was full of wrath over it, as over a lizard that ate away his heart. Therefore he longed for powerful enemies, to fight away his trembling, and thus to forget his fear.

So he collected his war-friends and went away like a dark cloud to the tribe of his enemies, challenging them to battle; and great was the fighting, and many were slain, but Tutanekai was victorious, so that he took many slaves and made great offerings to the God of War.

The great battle and the many offerings to the War God gladdened his heart again, and he was frightened no more.

But again, when he was home with his friend Tiki, his music wandered over the water, and took his heart away to Hinemoa, and it brought back her image, as she listened on the shore, and sorrow again grew within him. So he sent Tiki, his friend, to Hinemoa, to tell her of his great sorrow in being away from her, and to ask her to come to him and to his heart, that it might lose its fright and be full of gladness.

Watchful was Amukaria, but Tiki gave his message, and full of gladness answered Hinemoa: "Eh-hu, is then each of us growing in the heart of the other?"-and she promised to come to Tutanekai in a canoe, late on a black night, when he would play his sweetest music to call for her and to guide her in the darkness.

Amukaria, a great Ariki, was only willing to give Hinemoa as wife to a Rangatira of a very high mana, for her beauty was like the Morning Sun over the lake, and he, knowing the power and danger of such beauty, gave order that all the canoes should be taken off the lake. Thus, when the sweet music of Tutanekai called for Hinemoa, she wandered boatless on the shore, her heart full of tears, for she could not answer Tutanekai's calling."

Her eyes full of tears, Ngawai wandered along the rolling waves, telling herself in low tones, in Maori, of all the sorrows of Hinemoa, her ancestress. Ngawai accompanies her mutterings with movements which express despair; presses her hands against her heart; stretches her arms longingly over the ocean and presses them again to her bosom; then she speaks with a different voice and rapidly:

"One evening Hinemoa sat listening upon the rock Iri-iri-kapua, and suddenly the longing to go shook her as an earthquake. The trembling of love overtook her, and the courage of love overflowed her heart.

She went to the store-house, and took six dry and empty gourds, and tied them together with flax for floats, and she went to the edge of the water, called Wai-rere-wai, threw off her mat of kiwi feathers, and cast herself to swim the long, long way with the help of the floating gourds. Oh, my friend, behold Hinemoa like a beautiful flying star casting herself into the water!

Oh, Hinemoa, the brave!"

Silent is Ngawai : her lips are murmuring incantations to Tangaroa; her hands tremble; her eyes are fixed far away in the distance.

" $\mathrm{Ah}$, there, behold, she is there where the stump of the sunken tree stands in the lake-

Oh, Hinemoa!

Her arms are weary and her bosom is panting as she holds on to the branches of the tree.

$\mathrm{Ah}$, now has darkness swallowed her!-oh her heart is brave !-

On she goes, on, on, weary her limbs, her breast panting, darkness around; but nearer and nedrer comes the sweet music, nearer, nearer, and at last, with all her strength gone, her hands 


\section{ANCIENT LEGENDS OF THE MAORIS}

reach the rocks of Mokoia, where the hot spring is in the cave Wai-ki-miha. In this cave she took shelter, for she was cold, and trembling like a dead leaf. Trembling were her hands, but her heart was full of joy! Weary were her limbs, but her love was great and happy!"

Ngawai is striding with quick steps forward, heaving is her bosom, but in her eyes is fire and she is murmuring to herself. Her heart and thoughts are far away among the waves of the lake Rotorua, battling there with the water, as Hinemoa did, her ancestress.

"Long, long was the way over the water-oh, great was the love of Hinemoa!-

Whilst she was warming herself in the cave, there appeared at the narrow edge a slave, sent by Tutanekai, to fetch some water; and when he had filled his calabash Hinemoa called out to him: 'Slave, for whom is that water?'-and the frightened slave answered: 'For Tutanekai, my ariki.' Hinemoa spoke: 'If it is for Tutanekai, then give it to me,'-and the frightened slave reached her the calabash, and she drank and broke it on the rocks. The slave called out: "Why did you break Tutanekai's calabash ?' But Hinemoa never answered.

Again did Tutanekai send the slave, and again spoke Hinemoa: 'Give me Tutanekai's calabash'-and again the frightened slave reached it to her into the darkness, and she drank and broke it again.

When Tutanekai heard the words of the slave, he reached full of wrath for his warweapon of whalebone, calling, so that it sounded all over the island: 'Woe be to the man, woe be to the bad spirit, woe be to him who broke my calabashes! I will make a calabash out of his skull!"”

Harsh come the words from Ngawai's lips, but full of laughter are her eyes, and she wanders a while, smiling to herself.

"Tutanekai, in the dark cave, his powerful weapon lifted for a deadly blow cried fiercely: 'Who is that enemy, that I may give his name to my cup which I will make out of his skull?'

A voice answered softly out the darkness: 'It is I'-and the beautiful Rangatira, dressed in her flowing hair, stretched longingly her arms towards Tutanekai : ' $O$, Tutanekai, my ariki, kill me, kill Hinemoa.'

$\mathrm{Ha}$ ! the powerful weapon fell to the ground like a useless stick; forgotten was the God of War; forgotten the lizards: sorrow and fear and full of love sounds the voice out of the cave: 'Hinemoa!'

And from the rocks it echoed over the lake: 'Hinemoa!'”

Long is Ngawai staring in her hands, squatting down on the beach, then form her lips one word: "Hinemoa." 


\section{XIII}

\section{MAUI AND IRAWARU: A TRADITION}

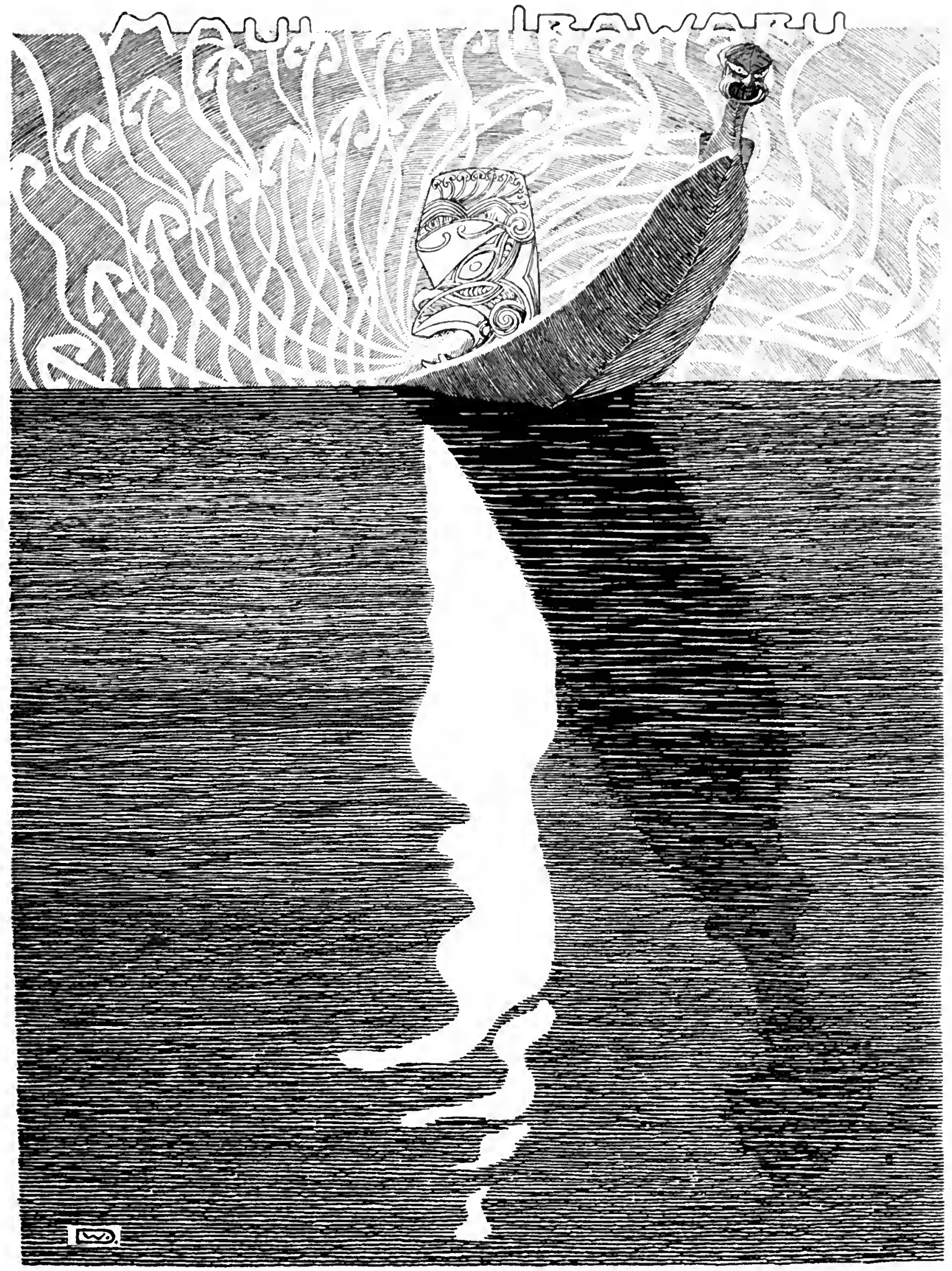



The Sun is setting, and our canoe is gliding, slowly, with the tide, up the river. Hupene, sitting in the prow, is staring to the west, and mutters lowly to himself; Ngawai plays lazily with the paddle, and is listening to what the old man is muttering, while the sandhills slowly pass by.

Hupene is staring into the broad reflexion of the Sun over the sea, but he has to close his eyes; and, bending his head, he commences a low-toned chant. Of Maui he sings, yes, of Maui, the hero of his people.

He sings how Maui and Irawaru once went together out to catch fish, and how Maui could not catch any, and Irawaru caught many.

Lower sinks the Sun whilst Hupene is murmuring, and the mighty spectacle of the sunset illustrates his chant. There is the Sun God Maui ready to steer his Sun-canoe into the Lower Worlds again, singing his song of farewell to his sister Hinauri, the earth.

Irawaru, the husband of Hinauri, had followed Maui in the morning upon the sea, to catch fish-Irawaru is the reflexion of the sun over the sea, wandering forth with the sun in the mornings to catch fish-what else could a man do on the sea?

Maui's fish-lines are the rays, shining through and between the clouds, and his sharp-pointed fish-lines may enter deep into the sea among the fish, but, having no barbs, they are not able to hold and land the fish in his canoe. But Irawaru's fishing-lines have many barbs, which you may see in the ripple of the water, and you may see too, the fish caught, and playing among Irawaru's fish-lines.

"Ah" (sings Hupene) "Irawaru caught many fish, a great many, and therefore Maui, who had not caught a single one became very angry, and in his wrath he entangled the fish-lines! Irawaru's line had caught a fish, and Maui, feeling it tear and try to free itself, hauled up the lines with all his might. Ha, when he lifts the fish now out of the water, he sees that it is caught by Irawaru, but he also sees the secret of the barbs on Irawaru's fish-hook."

The Sun is nearly touching the sea; Hupene is smiling cunningly to himself, and the canoe is gliding noiseless in the broad Reflexion of the Sun.

"Yes, Maui wanted to kill Irawaru, because he had deceived him with his barbs. His face becomes red with rage, and he asks Irawaru to help him land his Sun-canoe upon the shores of the Lower World, for he had reached Mahiku-rangi, the End of Heaven. Maui is cunning, and Irawaru, not knowing Maui's wrath, crawls under the Sun-canoe to help him lift it upon the shores of the Lower World, when Maui, with all his mighty strength, began to jump in the canoe, pressing it down, and nearly killing Irawaru. Then, springing out of his canoe, he jumped and danced upon Irawaru till his body grew longer and longer and took the form of a tail; and then with incantations Maui changed Irawaru into a dog."

So sings Hupene. The blood-red Sun seems to tremble and dance, before he sinks below the sea: he changes Irawaru into a dog which is now running as the last shade of light upon the mountains, whilst the Sun is entering the Lower World.

Our canoe is putting ashore to leave Hupene behind; but his sing-song is not ended yet, and he is standing on the shore before the golden evening-sky, and finishes his song, which Ngawai in the noiselessly on-gliding canoe is listening to and translating:

"Hinauri asked the parting Maui what he had done to her husband, for she did not see him coming back with him, and Maui answered that Irawaru had crawled among the bushes on the mountain; that she must go and call out to him: mo-i-mo-i, Irawaru, mo-i-mo-i. Hinauri did as she was told, and called and called, till at last a dog came running towards her, and she knew it was Irawaru, her husband, whom Maui had so cruelly changed into a dog. She broke out in a great lament, and at last she cast herself into the sea."

The earth follows the parting sun into the darkness. 

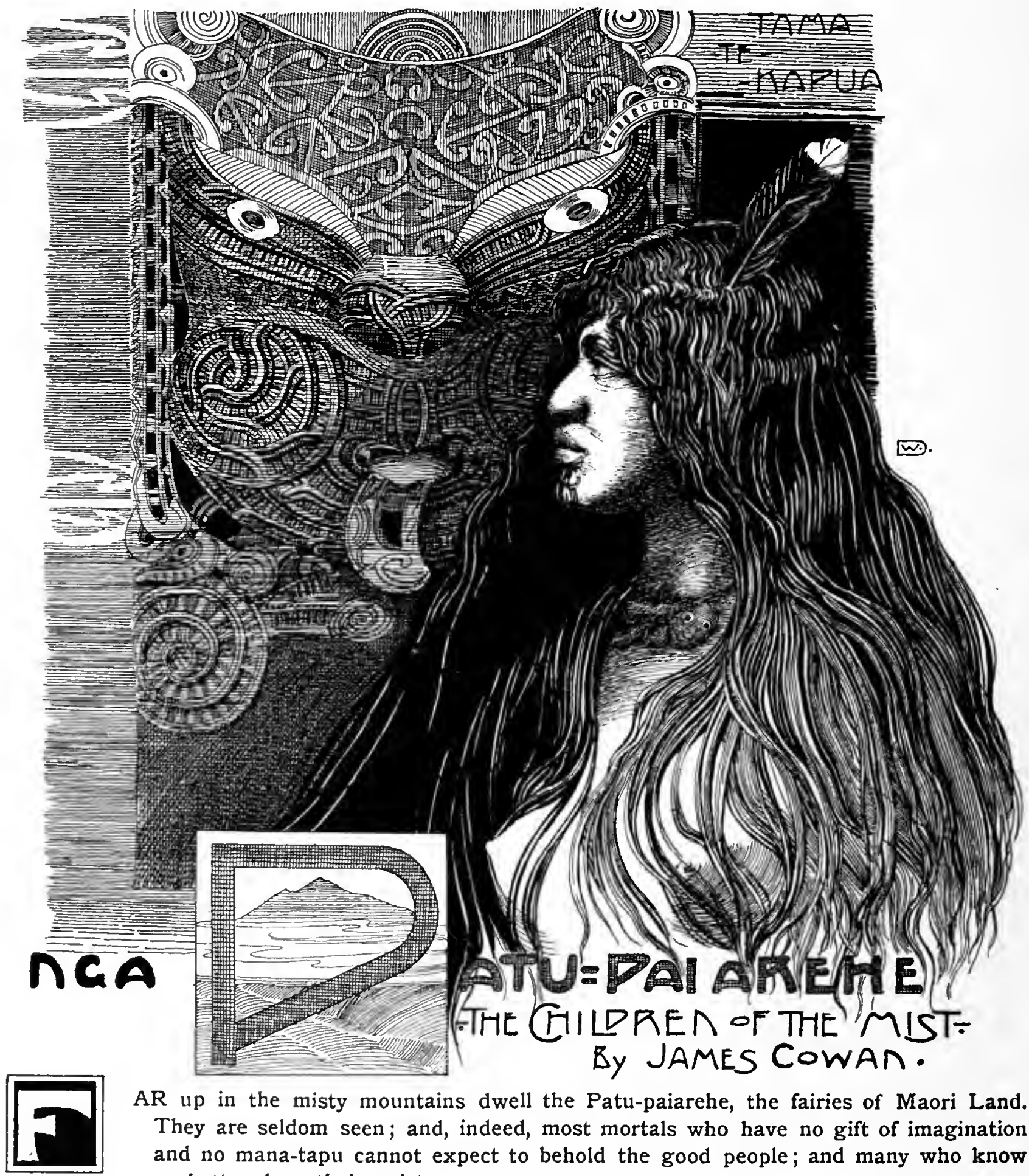

AR up in the misty mountains dwell the Patu-paiarehe, the fairies of Maori Land. They are seldom seen; and, indeed, most mortals who have no gift of imagination and no mana-tapu cannot expect to behold the good people; and many who know no better deny their existence.

It is supposed by some that they were really tribes of aborigines whom the Maoris found dwelling in this wild new land when they arrived here from the isles of Polynesia. But the old Maoris say that they still inhabit certain of the lofty forest-clad mountains of Aotearoa -a numerous people, some of them tiny gnomes and elves and pixies, some of them in the presentment of men and women of this world but smaller and exquisitely-shaped and with 


\section{THE PATU-PAIAREHE: THE FAIRY PEOPLE OF THE MOUNTAINS}

fair hair and fair skins just like Europeans. They are known to the Maoris by several names: Turehu, Tahurangi, Maero, and Patu-paiarehe; but their common designation is Patu-paiarehe. They are a bright, cheerful race, and take great pleasure in music. They are skilled in charms and the art of enchantment, and many a strange adventure has happened to the Maori who has had the temerity to venture into their haunts.

Like the elves of other countries, these fairies of Maori Land dread daylight, and appear only by night. Sometimes, on dark and gloomy days, when the thick mists descend and envelop the bare crags and deep ravines of the mountains of the South, the fairy people will be heard chanting songs in a thin sweet cadence, and then too will be heard the doleful sound of the fairy trumpet, and the faint and plaintive music of the Koauau, or nose-flute, and the voices of the fairy children laughing and singing above the clouds. But most of all they love the thickly-wooded mountains of the North, the Fish of Maui, where they live in their little pas, palisaded like those of the Maoris, and adorned with quaint little carvings and diminutive figures of fairy ancestors. Few mortals can discover those pas. They are hidden far away in the shadiest recesses of the bush, where the mist-maidens hover all day long, and where the Goddess of the Clouds descends nightly and covers her fairy children with her loving mantle. A Tohunga alone can perceive those stockades and houses of the Patu-paiarehe. To ordinary folk who penetrate the fairy country, those works of the little people are to all appearance mere trees and rocks and beds of ferns. But, if you have the wise eye and the Tohunga's understanding, you will see that the great rimu pine, with its drooping waterfall of golden foliage, and the lance-like kahikatea, tall and stately, the knotted and gnarled rata, the graceful nikau palm, and the lovely tree-fern, swishing gently its broad feather-fronds, are all part and portion of the Patu-paiarehe dwellings. For the fairies are ever of the forests: with the forest-trees they live, and with the passing of the forests they, too, pass away.

Many are the stories told of the fairy people and their encounters with mortals. One story says that it was from a party of fairies who were fishing by night for mackerel (tawatawa) in a bay in the far North, where they were joined by adventurous Maoris, and who, being surprised by daylight, fled, leaving their nets on the beach, that the Maori people first learned the pattern and hitch used in making the large seine fishing-nets.

Harmless as the Patu-paiarehe ordinarily were, they yet could worry mortals considerably on occasion. Some hapus of fairies, for instance, were in the habit of making periodical nocturnal expeditions to the homes of the Maoris and carrying off their wives. The korako, or albinos, sometimes seen amongst the Maoris are said to be the offspring of these unions; though in the far North they are spoken of as the children of kehua (ghostly visitants) and the women of this world. One of these stories of wife-abduction by the fairies relates to Mt Pirongia.

This beautiful mountain, with its dense woody ridges and valleys, its cascading brooks and its rocky fastnesses, is in Maori eyes the abode of hosts of Patu-paiarehe. In the dark moonless nights the lone eel-fisher out on the Waipa banks would start in affright when on his imaginative ear broke the sound of the fairies singing in their pas, and he would promptly fortify himself against their magic wiles by reciting potent karakia or incantations, and would chant a high quavering waiata to scare away the goblins of the night.

One day long ago Te Puhi and I were out pigeon-shooting far up the wooded slopes of Mt Pirongia. Evening had come upon us while we were intent upon bagging the "wingflapping children of Tane", and, as we had a long and toilsome journey down the bush ridges and across rapid creeks to make before we reached the old frontier township of Alexandra, my Maori companion and I decided upon spending the night in the forest. So, selecting a comfortable nook beneath the spreading branches of a fine old rata tree, we were soon enjoying a savoury meal of fat pigeons roasted over the camping fire, with the turnip-like pith of the nikau palm in lieu of bread. Tama-nui-te-Ra sank down beyond the westernmost peak into his ocean cave. The evening mists crept up from the murmuring streams and the gloomy gullies, and stole noiselessly along the dark forest ranges; and the Hau-ma-ringiringi, the soft 


\section{ANCIENT LEGENDS OF THE MAORIS}

fog-born dews, descended on the earth. And there was something uncanny in the long dancing' gleams of light which shot through the forest from our bivouac fire. The black shadows of the woodland swayed like ghosts with the flickering of the flames; and, Puhi, squatting close by the fire, gazed half fearfully down the gloomy forest aisles. And presently, in subdued tones, as if he were chary of arousing the genii of the bush by too loud a tongue, he told the story of the fairies.

"O friend of mine, listen! This is the belief of our people. This peak of Pirongia is an enchanted mountain; and it is well that you, a pakeha, are with me, else would I perchance be visited by the fairy tribe who dwell upon these heights. Pirongia is a Maunga-hikonga-uira,' that is a 'lightning-flashing peak'. Sometimes, when it is fine weather below on the plains, thunder will be heard rolling along the summit, and the lightning will be seen darting downwards upon its topmost peak. That is a tohu maté, an omen of death or misfortune to the Maoris: some chief of our tribe will die, or some untoward event will overtake the people. And high up around the top of the mountain live the Patu-paiarehe.

A great many years ago, many generations before the pakeha came to these shores and when the plains below us here were covered with the fires of the Maoris, there lived at the foot of this mountain, near the Waipa River, a chief named Ruarangi, of the tribe to which I too belong. His wife was named Tawhaiatu, and she was a woman of fine appearance, a beautiful woman in the eyes of the Maori. And the fairies of the mountain also considered her a fine wahine, for one morning when Ruarangi returned to his house in the early dawn, after having: been out all night eel-fishing, he found that his wife had disappeared. He searched long for her, and called her name aloud, but to no avail. When full daylight came, Ruarangi, greatly sorrowing, took his spear in his hand and placed his stone weapon in his belt and went along the track in the direction of the mountain where the fairies dwelt, for he knew that his wife had been carried off by a Patu-paiarehe. And, as he paused awhile on his way, he stretched forth his spear towards the fairy-mountain and wept, and chanted his song of lamentation for his vanished wife :

'My message of love blows afar,
Borne on the Eastern breeze,
A token of sorrow from the
Beloved one of your dreams,
Here stand I, in whose fond arms
You oft reposed. Oh, loved one of my
Heart! Return!
My head is bowed with grief.
Return! Incline to me your face ;
Like rushing fountains see my tears down fall.'

And lying in wait for two days near the forest pa, Ruarangi performed the ceremonies and repeated the incantations to recover his ravished wife. By stratagem he gained the place where she had been taken to by the fairy-the Patu-paiarehe did not perceive him, else had he been a dead man; and in haste he took her, before her fairy husband could follow in pursuit, and they reached their village on the banks of the Waipa in safety.

But Ruarangi and his wife knew that, though they were back in their home, the fairy chief or his followers would come by night and endeavour to regain possession of her. Their hearts sank as they communed long with one another in the shelter of their raupo house and planned how to prevent the fairies from again carrying Tawhaiatu away. And at night there came the spirit of one of their priestly ancestors, and it sat on the ridge-pole of their house and the thin whistling voice of the wairua spoke down to them as they sat by the fire in the centre of the whare:

'Oh, friends, I greet you! Hearken to my words. Smear the sacred paint of kokowai 
THE PATU-PAIAREHE: THE FAIRY PEOPLE OF THE MOUNTAINS

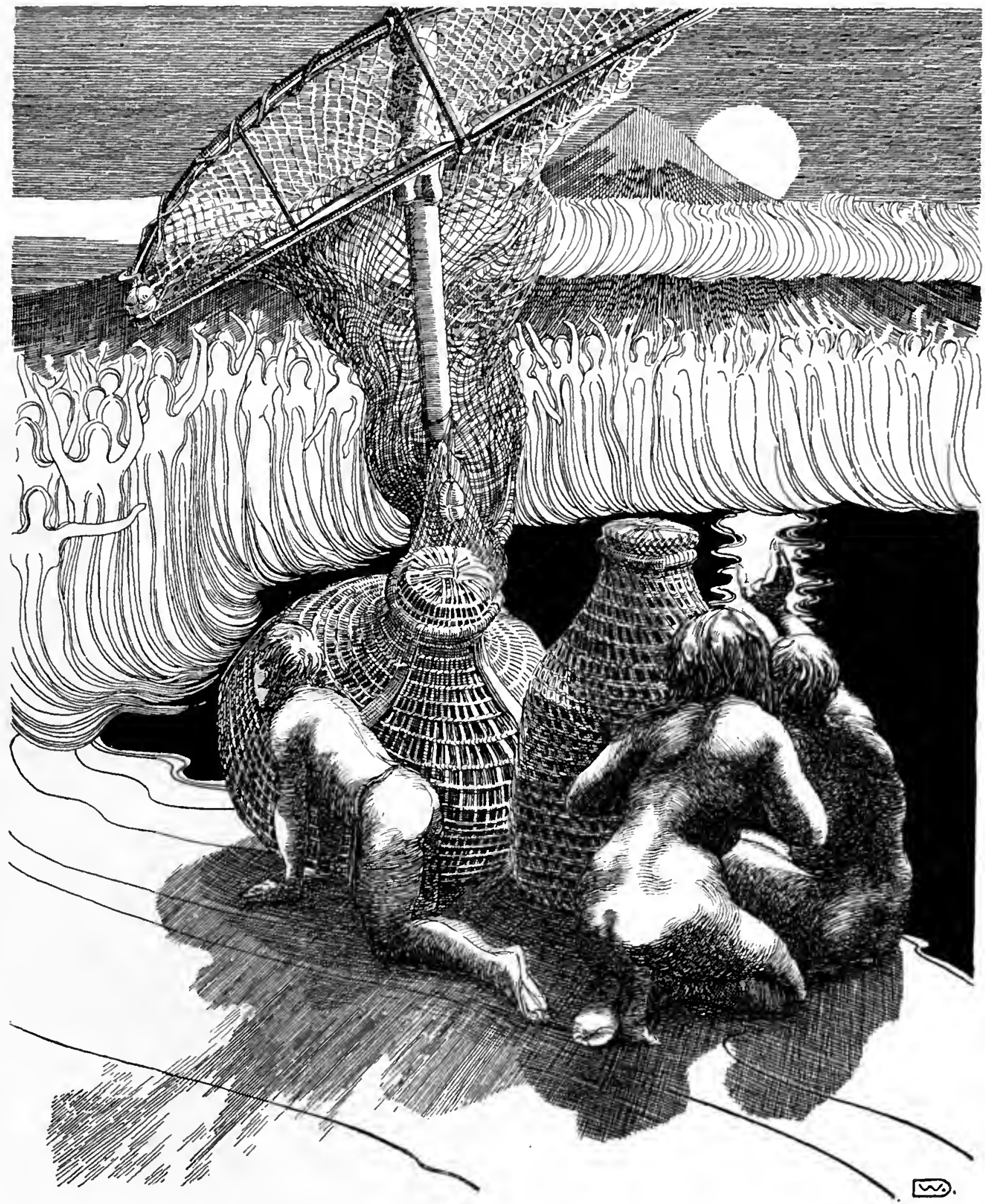




\section{THE PATU-PAIAREHE: THE FAIRY PEOPLE OF THE MOUNTAINS}

all over your bodies, and paint the inside of your house and the door-posts and the door and threshold also with the kokowai, for the Patu-paiarehe fear the kokowai as they do the fire of man. And, when the fairies come and see that you have covered everything over with kokowai, they will be afraid to enter into your house at night to steal the woman.'

So in the morning Ruarangi and his wife went forth and gathered kokowai earth (the sacred red ochre of the Maoris), and, mixing it, painted the whole of the inside of the house and the lintel-posts and the door, and also painted their bodies with it, and as evening came on they lit a fire in the house and awaited the coming of the fairy.

And at night, in the black darkness, there came to the house of Ruarangi the fairy chief from the misty mountain-top. He stood in the marae outside the door, and, as he looked into the house and saw the red kokowai on the posts and walls and on the bodies of the man and woman who sat by the fire repeating incantations, he grew afraid, and remained outside in the courtyard. He raised his voice in a song of lamentation, for he loved Tawhaiatu, but he could not prevail against the sacred kokowai and the powerful spells of Ruarangi. And then the fairy returned sorrowing to his dwelling on lofty Pirongia." days."

"And," said the pakeha, "Ruarangi and his wife lived happily together for the rest of their

"Ae ra" ("Yes,") gravely returned the Maori. "And who should know if not I? For Ruarangi and Tawhaiatu were my own ancestors. And perhaps I am half a Patu-paiarehe myself. Who can tell?"

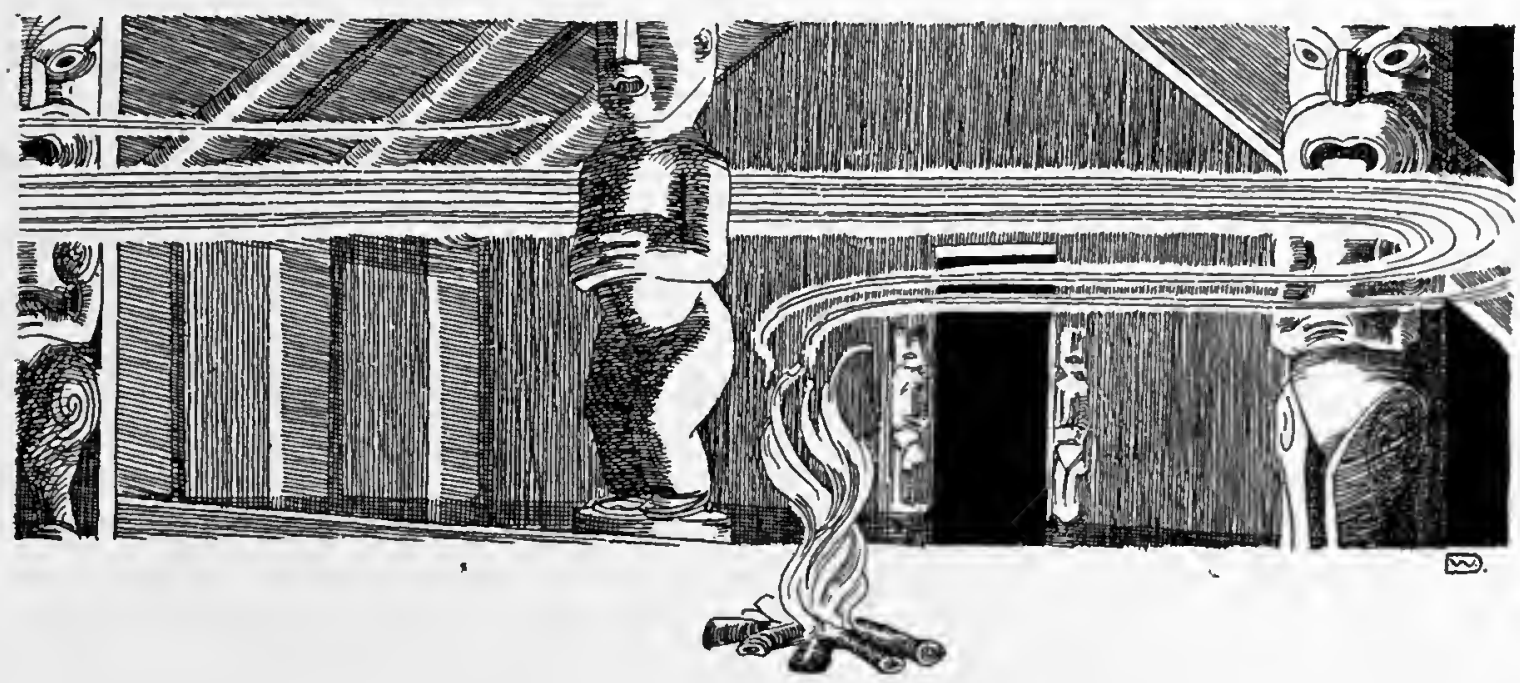




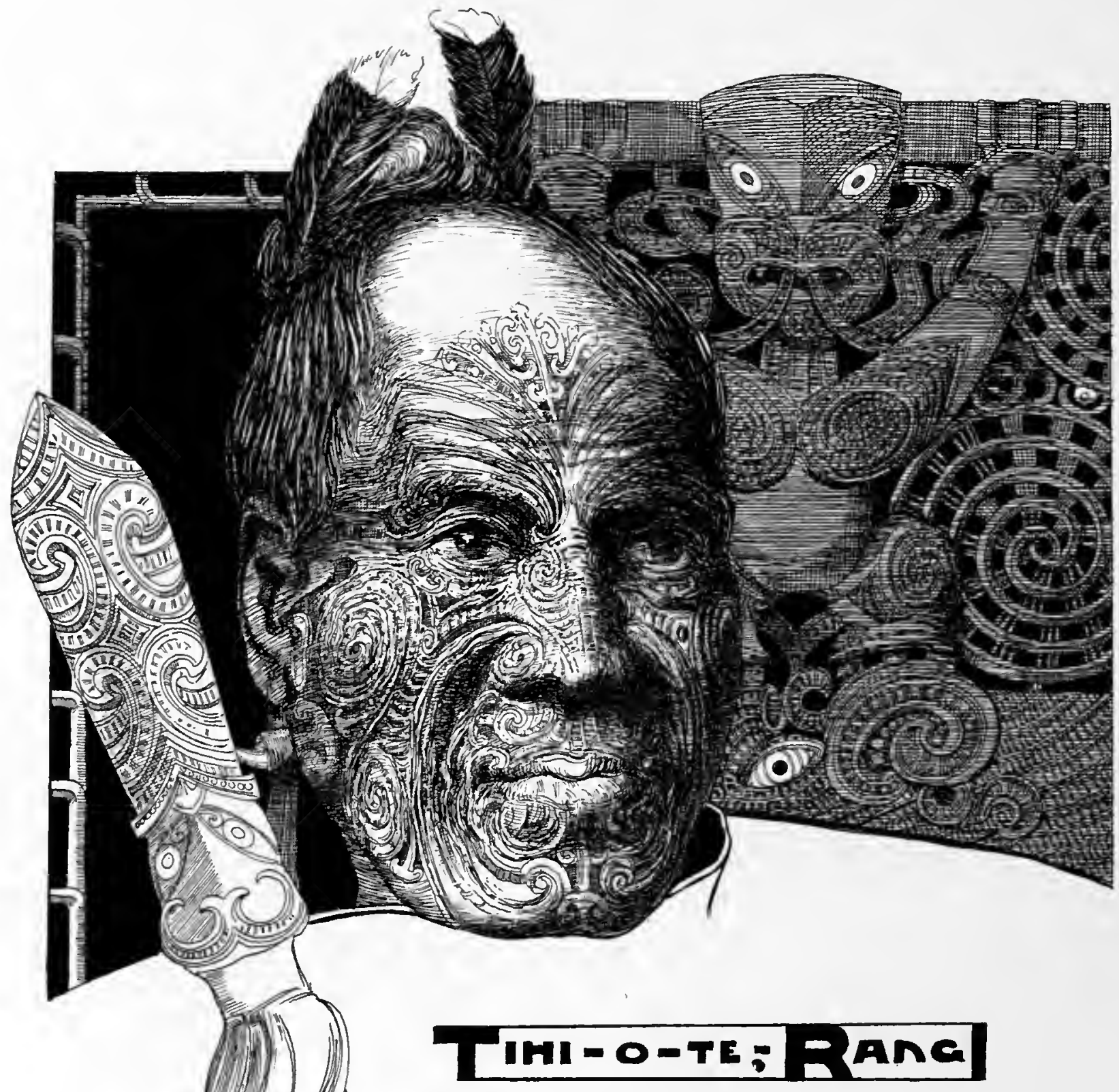

"The Path of the Spirits" - the mind of the young Maoris runs far now from battle and bloodshed, and but few bear the blood of the warriors in their veins, that blood which suddenly boils into powerful deeds.

Few carry the blood of the Rangatiras, who were masters over the bloodthirsty savages, or of the women, who were slaves, but who were sometimes Tohungas and powerful masters over the savage passions.

Out on the sea is the tribe, enjoying life and fishing under the summer sky; the pa (village) is lifeless, and the semi-darkness of the whare-puni broods lonelily over the past. The past, full of history for Ngawai-Hine-aroha, the friend: it is the whare-puni of her ancestors. Carved is there Tama-te-Kapua, the great Chief-Tohunga, her ancestor, who came from Hawaiki.

Silent is the whare-puni; silent are the carved ancestors; and silent is Ngawai, watching the mist covering the snow-clad mountains in the distance.

It is the hour of the fairies and the spells; the hour when the sun hides; and Tawhiri-matea, 


\section{TIHI-O-TE-RANGI}

the God of the Winds, is resting - the happy hour when man forgets his wishes, and the path of his mind is guided by the spirits of his destination: it is the hour when the woman-Rangatira knows that she is a woman, and will be a slave.

Ngawai's ancestors live in her veins, and her spirit wanders along the path of the past. She stretches out her arms commanding the spirits; her mind perceives; and speaks:

"Look, friend: many men and many women of my people lived and died, yes, a great many, since Tu-poho came, the great chief of the Nga-puhi tribe - ah, great was the number of his warriors-they came in the darkness of night, and their hearts were full of rage. Ah, a very great many were the slain of my people, and many were offered to the God of War by Tu-poho.

Day upon day lasted the feasting, for great was the hate of the Nga-puhi toward my people, and they ate them, and scattered the bones of my ancestors; ah, my friend!-The joy of the Nga-puhi was great, when they found Matike the beautiful sister of Tihi-o-te-Rangi; and they made her a slave.

Tihi-o-te-Rangi, the warrior and ariki, ah, he was in the mountains whilst this battle happened, and he was hunting for kiwis and pigeons whilst the women of the Nga-puhi tribe, day after day, were preparing the food for their warriors off the slain of his people, killing the women and children to feast the enemy.

Ah, terror would have been Tu-poho's! Tihi would have offered his blood to the War God; he would have swallowed his eyes; he would have eaten him and scattered his bones!-ah, Tihi was in the mountains; Tihi was in the mountains.-Ah, my friend.

At last a message came to him. Two women of his tribe came to him; they came naked and torn, the white flower of the clematis in their hair. By night they came and brought the head of their husband; they lit a fire before Tihi's house, and commenced their frightful tale of woe. They were cutting their faces and breasts with sharp stones, so that blood covered them all over, and terrible was their weeping and wailing.

Fearful to behold were the blood-covered women, calling for help and revenge, filling with fire of rage the heart of Tihi-o-te-Rangi.

He killed the little bird Ma-tata, and offered his blood to the War God Maru, that the war-tapu might come over him, and then he went his way to find Tu-poho.

Matike, the sister of Tihi-o-te-Rangi, was given to Te-marama, Tuwhare's daughter, as her slave, and great was the beauty of the two maidens. Matike, with her long flowing hair and tall figure, was the flower of the mountains; but the great eyes and soft swaying movements of Te-marama was the beauty of the flowers of the Pohutukawa, swaying on the shores on the North.

Crossing the rivers and walking along the shores of the sea was the tribe of the Nga-puhi, when they were followed by Tihi-o-te-Rangi.

He had held the Tangi over his burned pa and the bones of his tribe, and then he went and followed his enemies to free his sister. When he found the great party, he mingled with the slaves and carried baskets of food, and did the work of the slaves-ah, my friend, Tiki, the chief of great mana, carrying food like a slave!

One evening he met Te-marama, the daughter of Tu-poho, and she looked at him disdainfully and spoke: 'Truly, of all the warriors you are the strongest, and beautiful is the tattoo on your face and your body, and you do the dirty work of slaves! Ha, you have the face of the War God; but, truly you have the heart of a pigeon!' And he answered: 'You speak truth: I am a slave till I free my sister Matike; but soon I will show your warriors that they are women, for they fought women!' And Te-marama spoke: 'If you are Tihi-o-te-Rangi, truly then you are the best of all warriors, for you lower yourself to a slave to free a woman; but listen, Tihi: Matike is a slave no longer-for her beauty she is taken by the chief Takerangi to share his resting-place and his mana.' When Tihi heard Te-marama speaking thus, joy entered in his heart and he said: 'Sweet is it for the eyes to rest upon the Flower of the North, and her words give gladness to my heart! Listen! When Tihi-o-te-Rangi shall carry the powerful 


\section{ANCIENT LEGENDS OF THE MAORIS}

war-weapon of his tribe before his wrathful warriors into the land of Tu-poho, to kill and revenge my people, to eat and destroy the Nga-puhi, then shall revenge live in the one half of his heart, but it will carry peace in the other half, and joy and sweetness to the whare-puni of the Flower of the North!'

In the blackness of night he left the tribe, and went back to his destroyed pa again. There he sent messengers to all the tribes in the mountains calling them to revenge themselves upon Tu-poho. Warhapu after Warhapu followed his call, and all came burning for revengeah, a great many warriors all along the river were preparing for a great slaughter and a feasting on their enemy Tu-poho and his tribe, but the time for travelling was not yet come.

The greatest rage was in the heart of Tihi, and he built high palisades around his pa, the strongest and highest in all the land;-but in the shade of the evenings his mind kept ever forming the image of the beautiful maiden Te-marama: then his heart began to tremble, and the War God was hidden by clouds. And he sat lonely, and made presents to the Tohungas that they may hold incantations to the gods who govern the heart and desires of women. Ah, it was at that time that far in Nga-puhi Te-marama sat, listless and lonely, on the shores of the sea; ah, many days and many nights did she sit there, listless and lonely.

One morning, while the sun was rising out of the sea, she could bear it no longer: she called her slave to put some food into a basket, and bade her follow her.

$\mathrm{Ah}$, my friend, that was the beginning of Te-marama's great wandering over the pathless land, through the dark forests, and along the endless shores.

Ah, she followed the gods whose help the incantations of Tihi had gained, followed them, on and on, living on the wild berries of the forest and on the food that the shores of the sea offered her; sleeping under the rocks and upon the branches of the trees, always living in fear of the multitude of bad spirits-ah, the incantations of Tihi sent courage in her heart and the longing to overcome all fear.

At last she came to the pa Kau-ara-paua, and there she asked for Tihi-o-te-Rangi. But Tihi was living in his pa Tuke-a-maui; so she went up the river in a canoe, and the people of the pas on the shores were good to her, and gave her food, and marvelled at her beauty.

Many questions she asked as to where she might find Tihi-o-te-Rangi, and one evening, while resting in the whare of Rongo-mai, she related the story of her long wandering, and told that she was Te-marama, the daughter of Tu-poho-ah, my friend!

The face of Rongo-mai grew black! Ah, all his relatives were killed by Tu-poho! Up he jumped, and walking up and down before the assembled people he swung his Taiaha (war-weapon), and with rolling eyes and frightful jumps and movements he chanted terrible words to the spirits of his relations, who were still crying in the forest, for their bones were scattered over the world and their flesh was eaten, and their death never revenged. His rage was terrible, and, suddenly jumping forward, he killed Te-marama with one powerful blow of his weapon!

Ah, his frightful words had filled the hearts of the people with rage and revenge, and terrible cries of wrath and spite filled the whare! They took the heart of Te-marama, and offered a part of it to the crying spirits of their relatives; then they cooked the remaining part for Rongo-mai, who ate it in spiteful insult to Tuwhare. Then they cooked the body of the girl, who came to give gladness to the heart of Tihi-o-te-Rangi, their most powerful chief, and feasted upon it!

Ah, my friend, Tihi was near, but the joy of his heart and the sweetness of his mind was killed; the heart, beating for Tihi, was offered to the gods of revenge-ah, my friend!

The slave escaped, and her tears were floods, and frightful her cries, and terrible her words of insult when she met Tihi: ' $O$, Tihi, look at Te-marama, who was truly your slave, look upon her, look; look upon her bones in the mouths of your people of dogs; go and look for the eyes of your girl in the stomach of the dog Rongo-mai; go, that the dogs of your people may devour you, you rangatira of a tribe of dogs !'

Up flamed the blood of Tihi, his eyes burned, his hands trembled; with one blow of his mere he killed the slave that he might not hear more. He cut his hair, and offered it to the gods who 


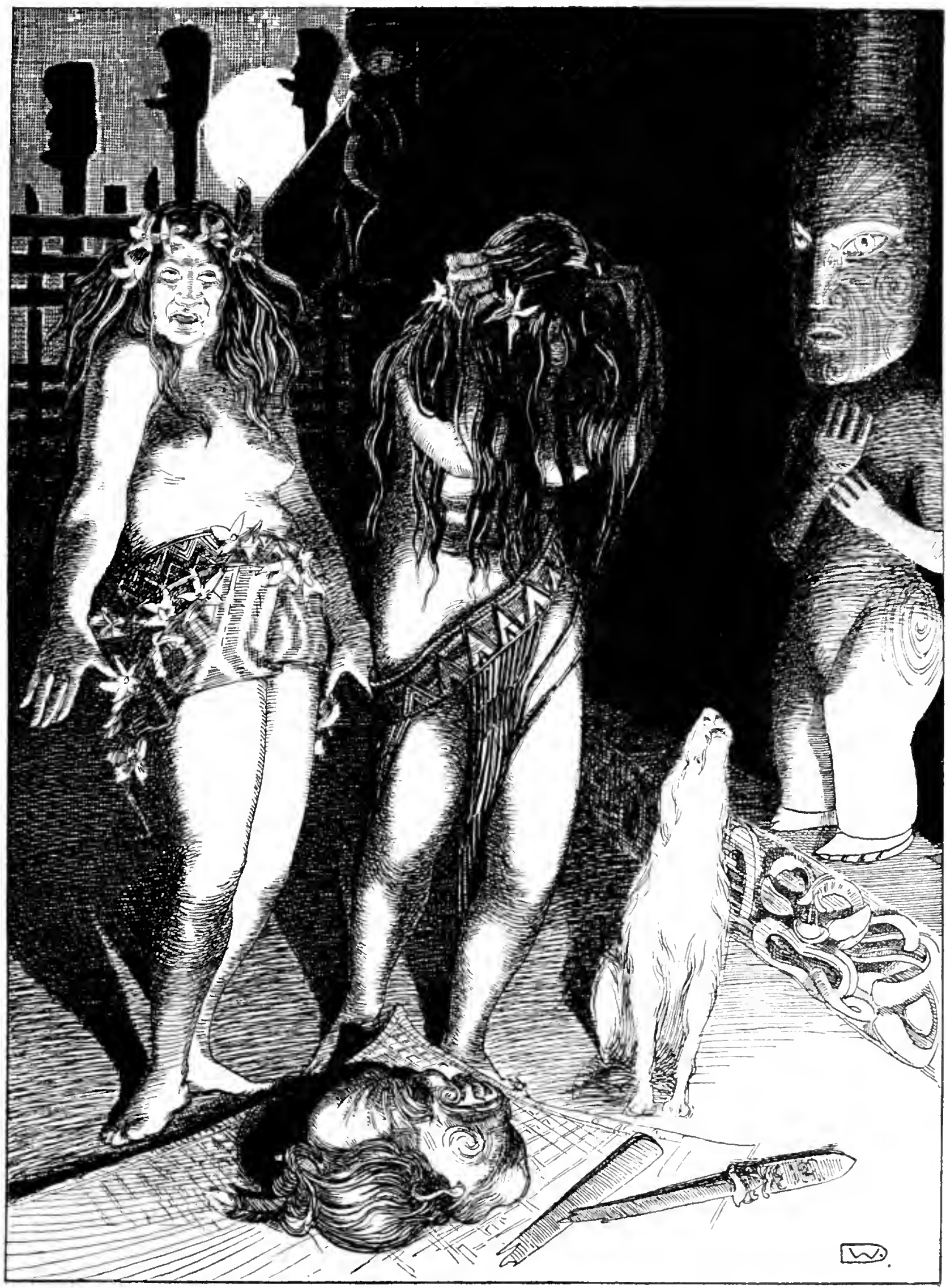


, " 
have the rage of man in their keeping, and then he went to revenge Te-marama! He killed Rongomai and all his family and his relatives and friends and all who took part in the feasting and all who were related to them; and he invited all his tribes to feast upon the slain, to shout insult and spite over the dead and their bones far into the world, and to curse their bones, to break them, and scatter them all over the world !-

Ah, ah, my friend-but Tihi! Ah, from that time he sat alone at the fire in his whare-puni, brooding and sorrowing and crying; and happiness never again entered his heart-Tihi-o-te-Rangi! But then, my friend, he collected his warriors against the enemy Tu-poho, and from that time the frightful war was waged between the two insulted chiefs of which the people of both tribes know numberless doleful songs."

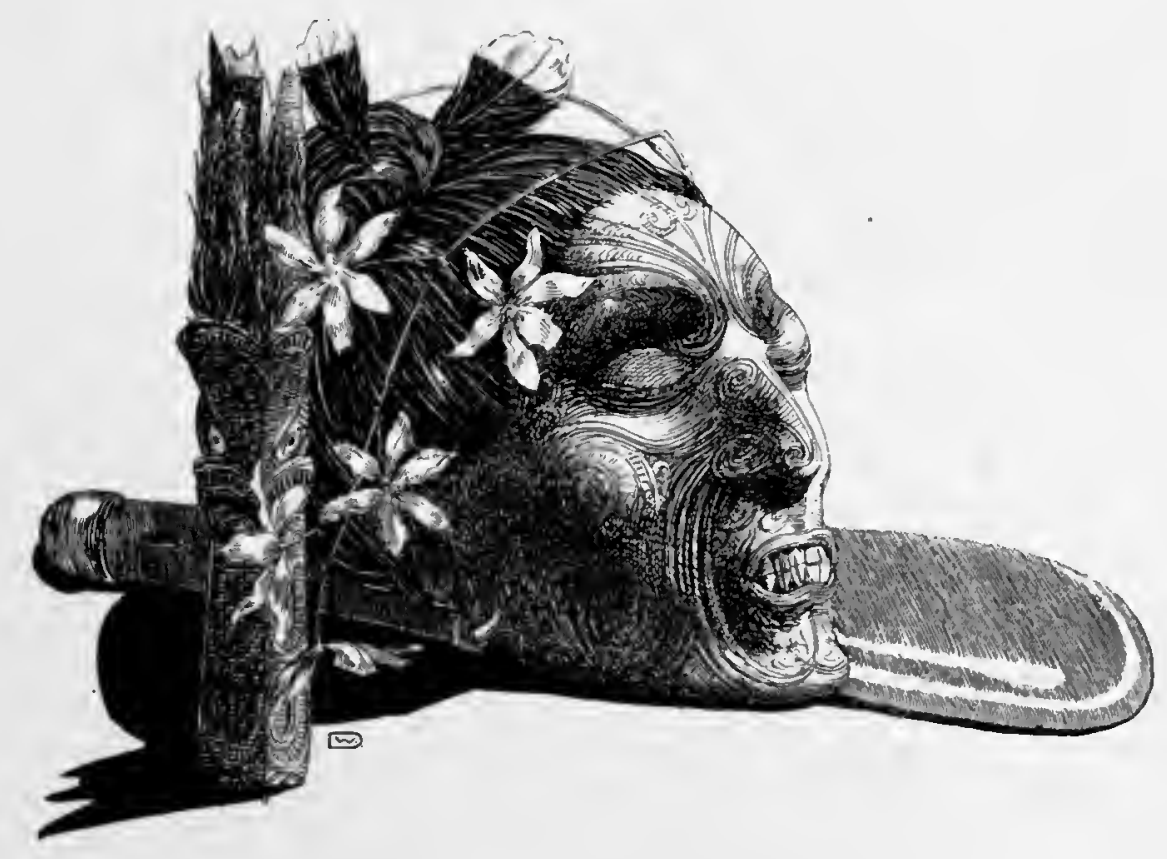




\section{THE BATTLE OF THE GIANTS}

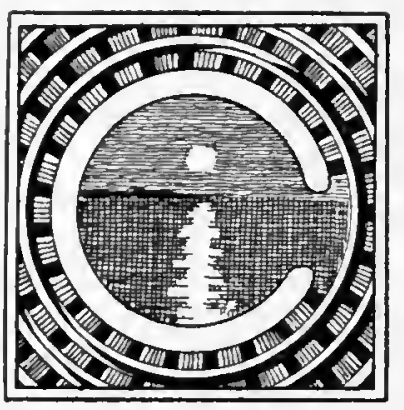

ALMNESS reigned over the world, and Ngawai's murmurings died away in the silent night.

Incantations.

Yes, Ngawai, your story was beautiful, your story of Te-marama and Tihi, the warrior; but many hours has the night, and my mind wandered out to the Little Ones, the Patu-paiarehe, and they told me the spirit of Te-marama was not dead, but still wandered along the path that leads to gladden the heart of man; and her name was Ngawai.

But, Ngawai, look, the fire has burnt lower and lower, and no fresh wood has been put on the embers — but look, there, yonder! Look how the snow of the mountain is hailing joyfully the Morning Sun.

"Ah, too young is still the morning, my good friend, for the wanderings of man, rest and listen-_"

Beautiful crimson and golden, and blue and silver-white, with hushing shades and flashing lights rises the mountain-world into the new-born day. Like God's own messenger of peace towers the snow-clad giant over the world, breathing his grandness into the universe.

How small is man, wandering over the endless base of the giant, over the dead and burnt stone-wilderness! No green, no grass-the friend of man-enlivens the vastness out of which the eternal silence is growing into the lonely magnificence.

This is Ngawai's story:

\section{THE GIANTS}

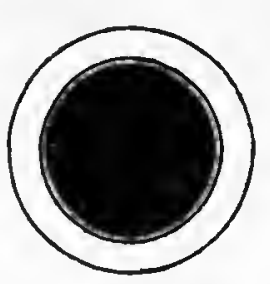

her suitors.

NCE the volcanoes Taranaki, Ruapehu, and Tongariro dwelled together. That was the time when Tongariro in her wonderful beauty had captured the fiery hearts of the two giants, so that their joy filled the heavens with majestic outbursts and covered the earth with their dark-glowing heart-blood of fiery lava and molten stones.

Softly then answered the gently ascending Steam-column of Tongariro, smiling and swaying, gold-bordered by the setting sun; smiling at both

Ah, Tongariro was a woman!

Both, the straight and simple Taranaki and the rugged and strong Ruapehu, their cloudpiercing heads covered with spotless snow, or adorned in their passion-glowing lava-streams, were beloved by Tongariro; but the snows of the winter and the suns of the summer came and went from the first time, to the hundredth time, to the thousandth time, and still Tongariro was undecided whom she would prefer for a husband.

She became the sacred mountain of the Maori people; her beauty captured the hearts of all, so that she became the possessor of the highest tapu, and no foot dared walk upon her, and only the eyes of the new-born were directed towards her; and the eyes of the departing rested full love upon her beauty, whilst they wandered to the Reinga. 
THE BATTLE OF THE GIANTS

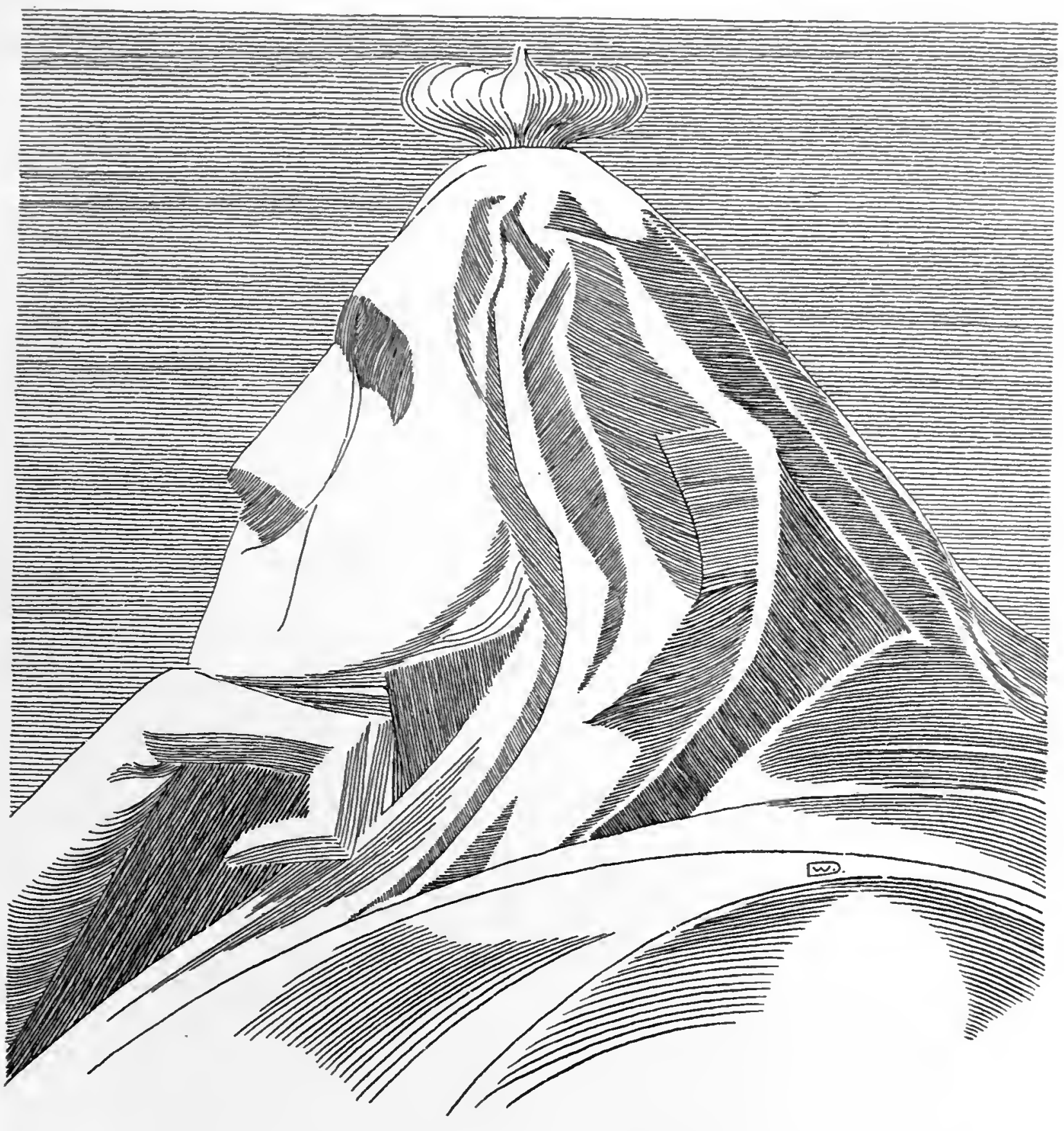





\section{THE BATTLE OF THE GIANTS}

The eyes of generations upon generations of man.

Beautiful to behold from all the lands was the great love of the giants; now all covered with glittering snow, now hiding in the clouds and bursting forth, covered with strange and wonderful beauty; now girdling their bodies with clouds and lifting their endless heads into the golden heavens; and now again breaking forth into terrible passions, covering the earth with blackness.

$\mathrm{Ah}$, Tongariro roused the passions of the giants: she made the volcanoes tremble! Their blood of fire and boiling stones shook them, the thundering of their voices, roaring insults at each other, made the earth tremble. Streams of lightning pierced the nights, and black smoke of deadly hate darkened the days, and the ears of man were filled with the roaring hate of the giants, and their wondering eyes beheld the beauty of Tongariro, smiling at both!

At last the two rivals decided to fight for Tongariro!

Now followed days of silence. The giants stood there grim and silent to the world, but they were gathering strength, and were melting stones in their insides, and lit terrible fires, their powerful weapons. So they stood silent and grim; the sun gilding their beautiful garments of snow, and Tongariro smiled at them with her graceful swaying column of steam; and the Maori people looked wonderingly upon the peaceful landscape.

Then a rolling grew into the nights, and rolling filled the days; louder and louder, night after night, day after day-a terrible groaning, dump and deep. Suddenly a crashing thunder shook the earth, and bursting forth from the mouth of Ruapehu a fiery mass of molten stones and black hate and fury fell upon Taranaki, covering him with a terrible coat of fire, whilst the flying winds howled and the melted snow-waters fled thundering down into the valleys.

A beautiful straight form gave the mass of fire and ashes to Taranaki-but he shook in terrible rage! He tore himself out of the ground, shaking the earth and breaking the lands asunder; he tried to fly at Ruapehu, to kill him with his weight. But Ruapehu made the water of his lake, high up in the snows, boil, and, hurling it down, it filled all the rends Taranaki had made in the earth, and burned all the inside of the earth and of Taranaki himself. He now, tearing the air with his roaring cries of pain and thundering howling of rage, threw a tremendous mass of stones at his enemy, and broke the highest cone, the loftiest peak of Ruapehu, so that his looks were not so majestic, and his reach not so far into the skies.

Ruapehu now, in deadly hate, swallowed his broken cone and melted it; he lit terrible fires in his inside, which spread to the lake Roto-aira, so that it rose and boiled, the steam covering all the world and blinding Taranaki. Then Ruapehu filled himself with the boiling water, and, throwing it out of his mouth down upon Taranaki, it filled all the crevices, and it lifted him, for he himself had loosened his bonds with the earth; and now, darkening day into night, he sent the molten mass of his swallowed cone against his enemiy, so that he was compelled to retreat: blinded by steam, burned in his inside by the boiling water, and covered with the molten mass of the cone of Ruapehu he himself had broken.

He groaned, and rose, and tumbled, and shook himself; and he felt for a way to the sea to cool his burning pain; howling in unbearable pain he had to run, in order to get out of reach of Ruapehu, deeply hollowing his path through the lands. But his conqueror, Ruapehu, melting all his ice and snow, sent it as boiling water into this deep path, that his enemy might not come back again, for his strength also was exhausted.

On to the sea went Taranaki, and, when his pain had left him a little, he looked back at his conqueror, and saw how his three peaks were again covered with fresh snow, and how he was now the supreme lord over all the lands and the husband of Tongariro. They two were now the arikis over all the land; but it was waste now, and dead, for the terrible fight had killed all the people and the living beings all around. Once more a burst of black anger broke forth from Taranaki, and again it was answered by a wonderful swaying and smiling 


\section{ANCIENT LEGENDS OF THE MAORIS}

steam-column from Tongariro; and then he went and wandered along the coast till he had found a place for his sorrow. There he stands now, brooding on revenge.

"And my people know that one day he will come back in a straight line, to fight Ruapehu again; and none of my people will ever live or be buried in that lime; for one day he will come back to fight for Tongariro-who knows?"

But the path of Taranaki to the sea is now the Wanganui River.

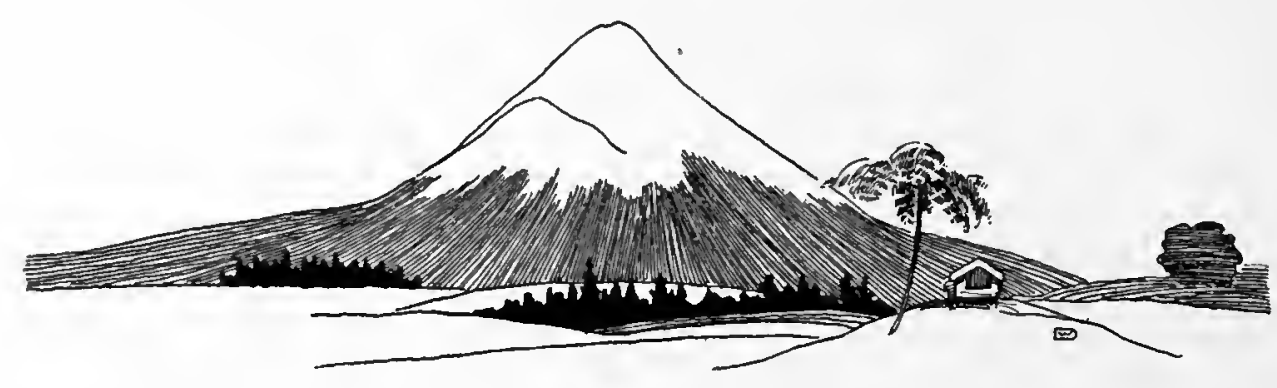


THE BATTLE OF THE GIANTS

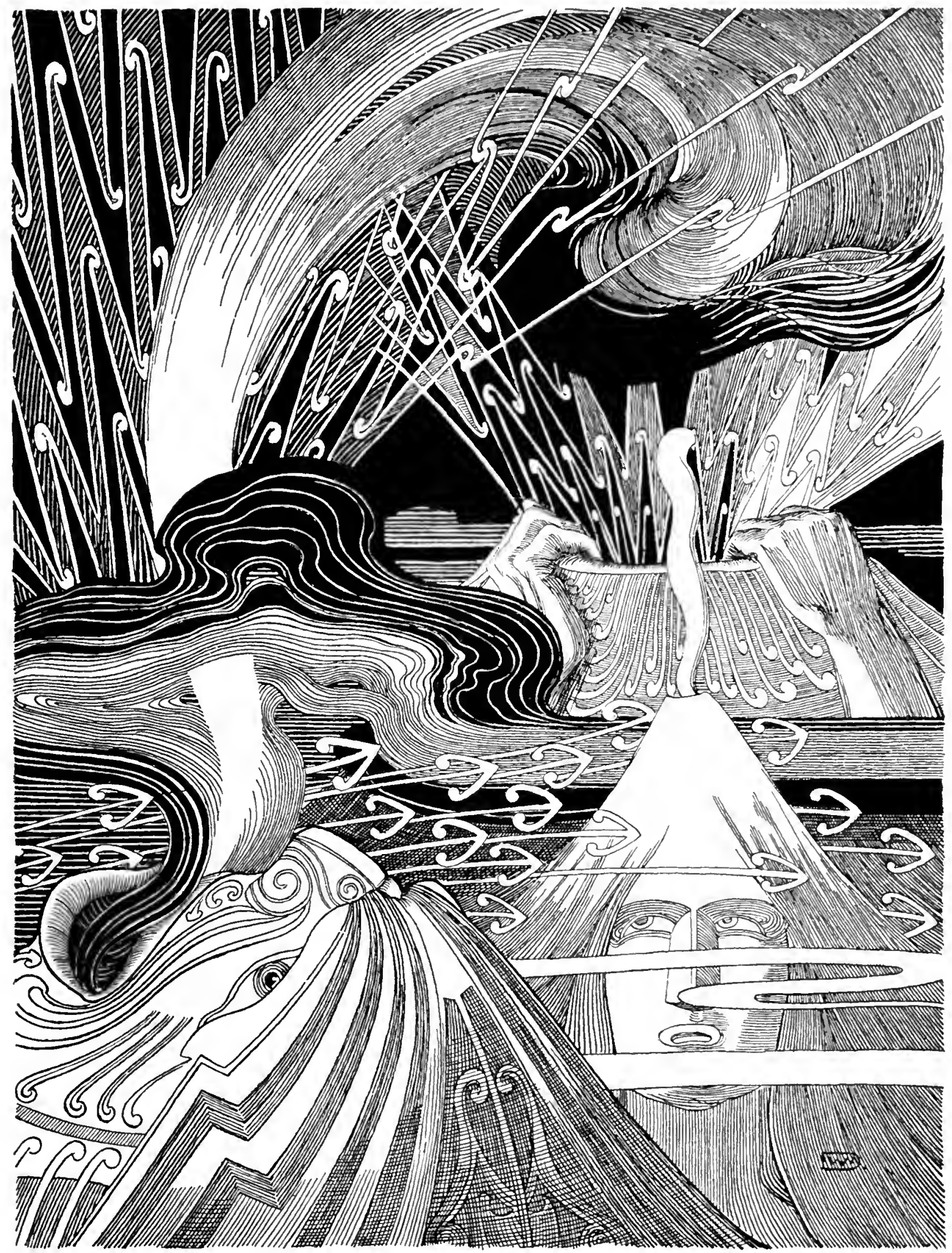




\section{XVII}
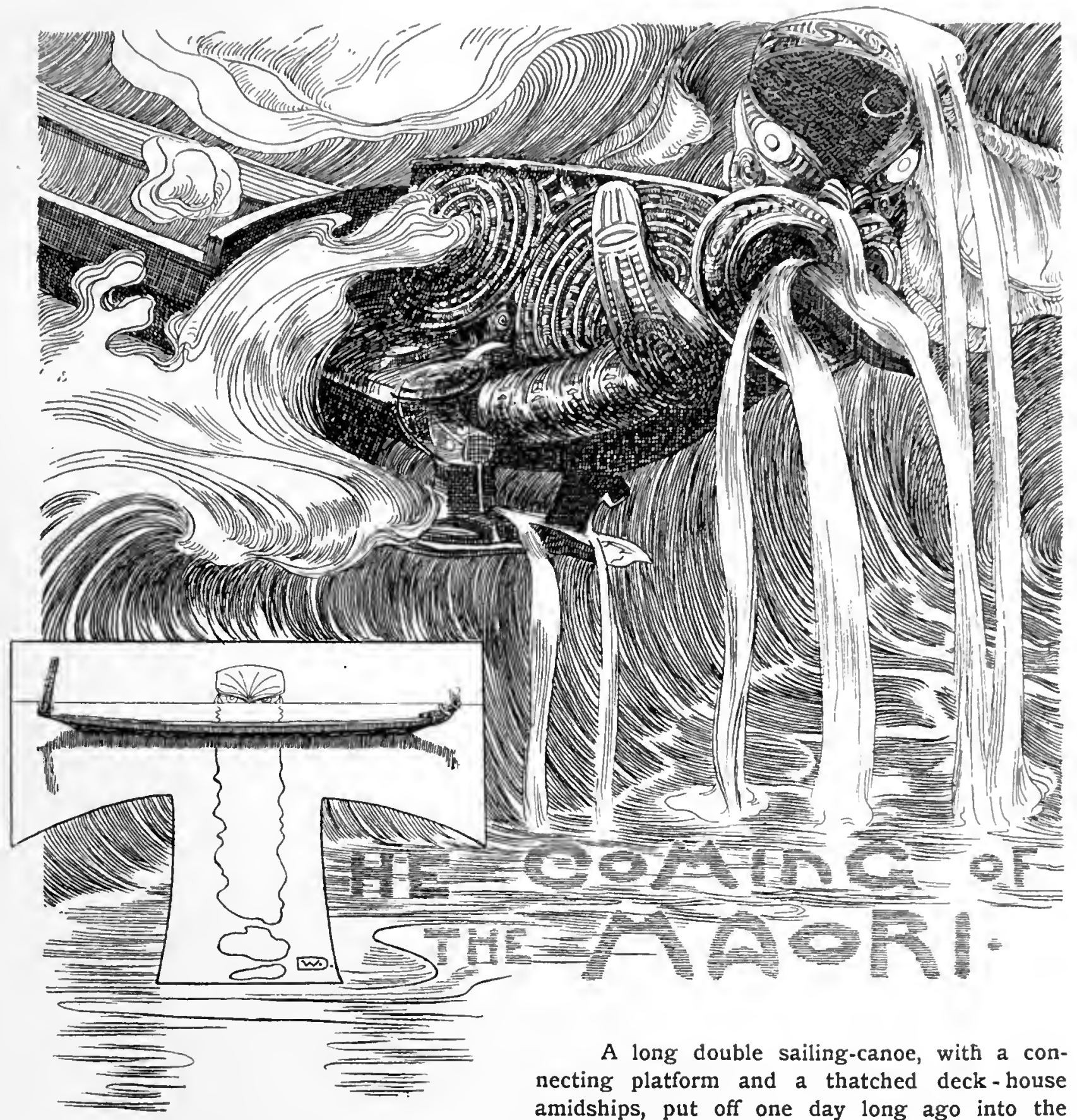

A long double sailing-canoe, with a connecting platform and a thatched deck-house amidships, put off one day long ago into the Great Ocean of Kiwa from the palm-clad shores of Tahiti the Golden, in the far South Seas. A multitude of brown people stood on the shining beach, with loud cries bidding farewell to the brave band of kinsmen who were adventuring into the vast unknown places in search of a new and wider land. In their midst, leaning on his staff, was the patriarchal chief Hou-mai-tawhiti. Bent by the weight of years was the ancient man, and his long white beard swept his breast. And as the canoe-paddles took the water and she gathered way, a voice of Hou' was heard crying his poroporoaki, his farewell to the crew. "Go! Go! Depart to your new land. Leave war and strife behind you. Follow not after the God of War; hold to the deeds of Rongo the Peaceful. Haere! Haere! Haere atu ra!"

And then the sails of the great canoe were hoisted, the foresail, the main and the mizzen, 


\section{ANCIENT LEGENDS OF THE MAORIS}

for she had three masts-lofty triangular mat-sails with the apex downwards. Like a huge sea-bird she swept across the blue lagoon to the reef-opening; then she bravely mounted up on the great ocean-rollers, te-whare-hukahuka-a-Tangaroa ("the sea-god's foamy dwelling"). The brisk trade-wind filled her sails, and away she bounded into the south-west, growing smaller and smaller - a mere speck upon the great waters, until she faded from the vision of the keenest watcher on the shore.

This was the Arawa, most famous of all the historic fleet of canoes that voyaged thousands of miles across the Pacific to this new land Ao-tea-roa, the Great White World. Her commander was Tama-te-Kapua (Son of the Clouds), the son of the venerable Hou-mai-Tawhiti. And of Tama's doings and the perils that befell the Maori Mayflower I shall briefly tell.

Tama-te-Kapua was a bold and cunning man. He invited the high-priest Ngatoro-i-Rangi on board the Arawa to perform the sacred rites appropriate on the occasion of putting to sea, and then refused to allow him on shore again. He carried him off across the ocean to be the Arawa's priest, knowing that Ngatoro' was under the protection of the atuas and ancestral spirits of the race, and that he was indeed almost a god in himself.

While crossing the ocean in search of the new land Ao-tea-roa, Tama-te-Kapua clandestinely gained the affections of the lady Kearoa, the wife of Ngatoro-i-Rangi, who had accompanied her husband. When Ngatoro' discovered this, he resolved to destroy the canoe and all that were on board. So to this end he directed the bow of the Arawa straight towards the Waha-o-te-Parata, the Mouth of the Sea-monster, a terrible whirlpool, or maelstrom, in mid-ocean, which had sucked down many a vessel to destruction. The sea-battered craft entered the outer circle of the maelstrom, swiftly approached the fatal spot where the Ocean God drew down the waters with an awful, roaring noise. The people in their terror cried to Ngatoro-i-Rangi to save them, but he heeded not. Then stood up Ika, one of the chiefs on board, and recited a karakia to Rangi, the Sky God, praying him to save the canoe, te-kaokao-o-Tane, the ribs of Tane the Tree God, and beat down the angry waves of Tangaroa.

But the ears of the gods were closed, and downwards surged the Arawa. The roaring of the Waha-o-Parata grew more terrifying, and the men and women and children on board cried again to Ngatoro-i-Rangi to save them. And the high-priest rose, and in a wild chant he invoked Tangaroa the Ocean God, and called upon many a deified ancestral spirit. Loud pealed his awa-moana, his rhythmic storm-assuaging incantation (beginning "Unuhia, unuhia te pou tapu, ko te pou mua, ko te pou roto"). He besought the gods to draw out the canoe from the dread tumult of water, the sacred canoe that once grew as a tree (pou-tapu) in the enchanted Forests of Tane-to save from the throat of the Ogre of the Depths the ship of Ngatoro'. He called upon the spirits of Ruarangi, of Maui-tiki-tiki-o-Taranga, to descend by the path of Tawhaki the God-man from the heavens, and "clear from perils all the ocean track of Ngatoro'."

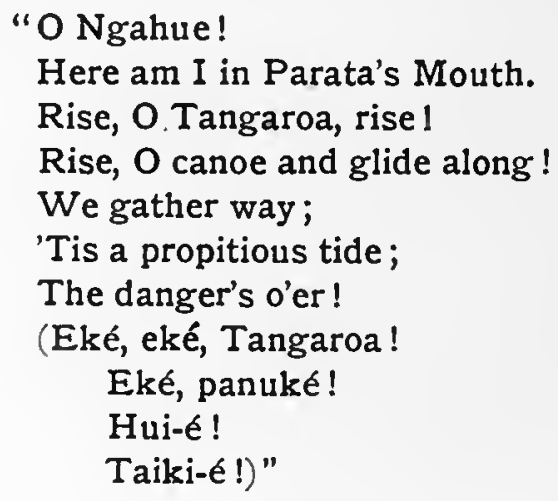

And the mana tapu, the supernatural influence of that awa-moana, and of the Tohunga, was such that the terrific lashing of the sea was calmed, the gaping whirlpool closed again; the great billows ceased to tumble, the heavens grew light, and the canoe sailed on once more in 
THE COMING OF THE MAORI

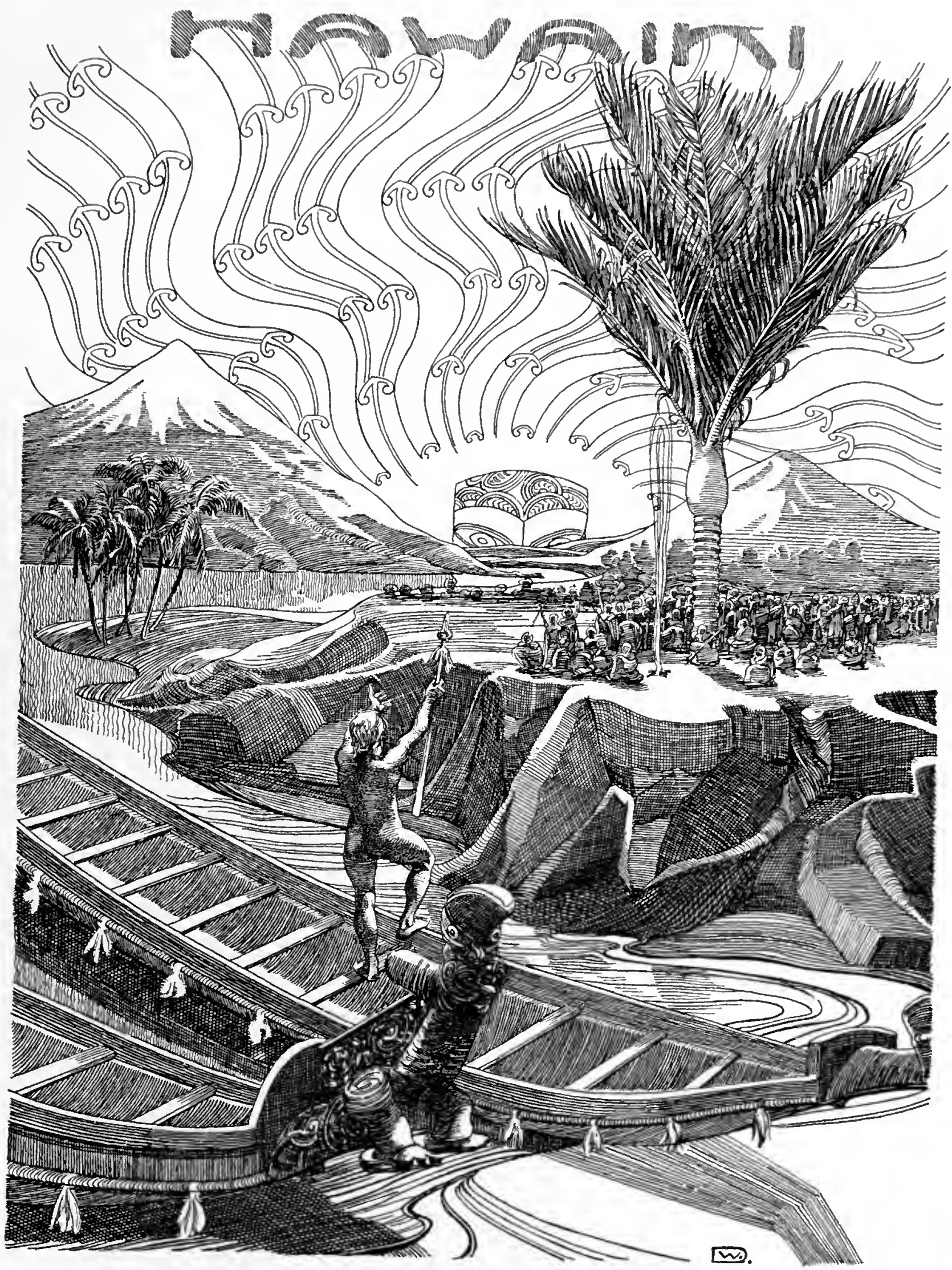



THE COMING OF THE MAORI

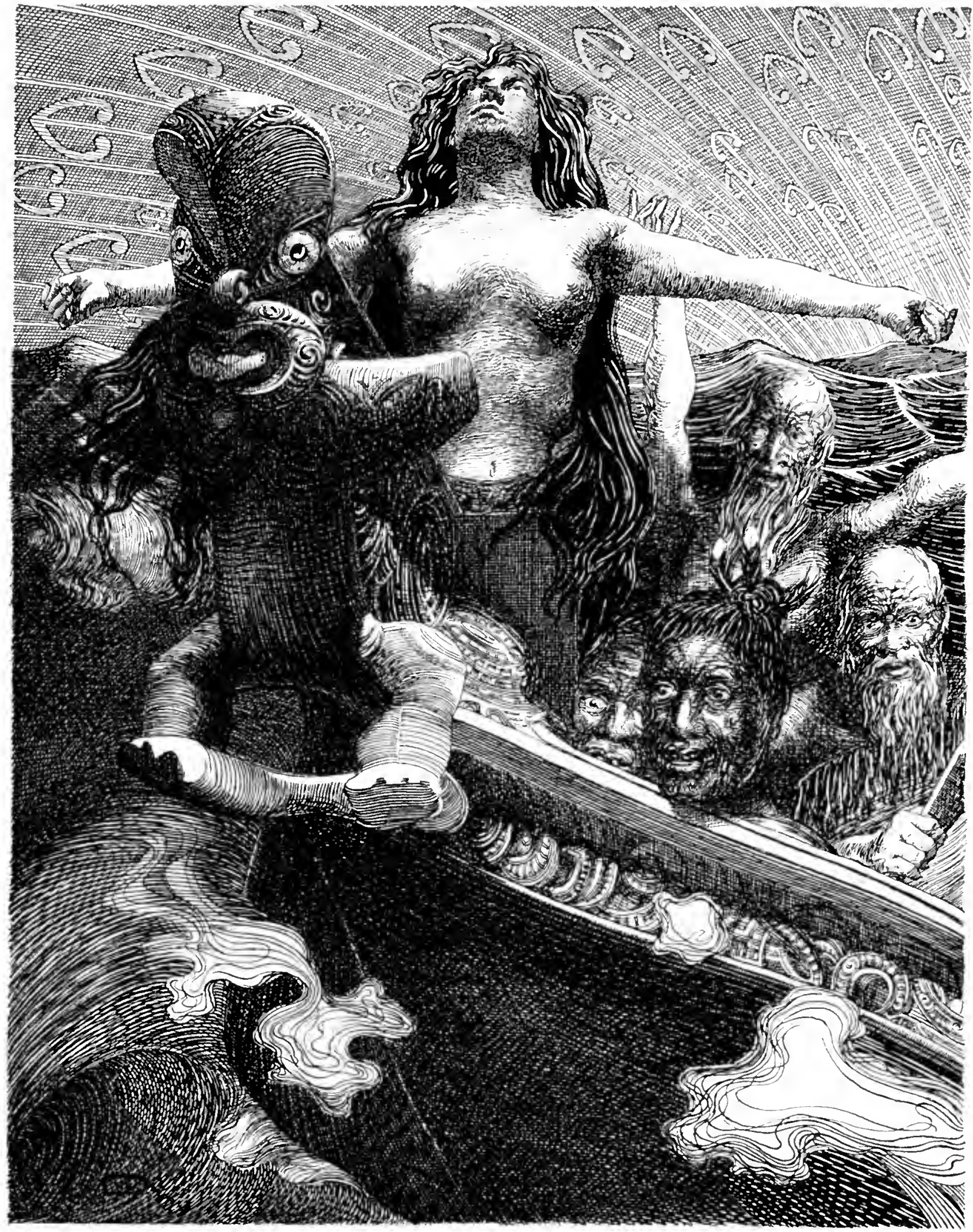





\section{THE COMING OF THE MAORI}

safety over the long heaving swell of the Ocean of Kiwa. Magical indeed was that ringing seachant-of Ngatoro', as potent in its peace-compelling numbers as that mermaid's song of which Oberon discoursed to Puck in A Midsummer Night's Dream:-

"Thou rememberest since once I sat upon a promontory,
And heard a mermaid on a dolphin's back
Utter such dulcet and harmonious breath
That the rude sea grew civil at her song,
And certain stars shot madly from their spheres
To hear the sea-maid's music."

It was midsummer when the sea-worn pilgrims at last made landfall on the far-extending coast of the Long White World. As they drew close in to the shores, near the East Cape of the North Island, they saw that the cliffs, shining like chalk in the sun, were fringed with beautiful trees, the pohutukawa. Groves of these trees, too, grew right down to the tide-edge, and the rich crimson flowers which covered them were reflected in glowing red (ura) in the calm and glassy waters. Several of the people in the canoe wore red ornaments, relics of Hawaiiki, in their hair. On seeing the beautiful red flowers they impulsively threw their own head-ornaments into the sea, and, when they leaped ashore they ran to gather the blossoms of the pohutukawa to deck their hair, only to find to their disappointment that they fell to pieces at a touch.

The first place where they landed was Whanga-paraoa (Whale Harbour), so called because they found a great sperm-whale stranded there. Here were performed the ceremonies of thanksgiving for safe arrival, the offering of seaweed-the spoils of Tangaroa-and of the earth of the new country to the gods. The sacred fire was kindled and the sacred kumara roasted, in burnt sacrifice to the spirits of this vast strange land. They coasted along, and finally hauled the canoe ashore at Maketu, whence they travelled inland, exploring and making homes for themselves. It is their descendants who now people the Geyserland district of Ao-tea-roa, extending from the Bay of Plenty southwards to the great central lake of Taupo. Ngatoro-i-Rangi the high-priest and his wife took up their abode on the island of Motiti. From Ngatoro' sprang a line of powerful priests of Ariki rank, and one of his direct descendants is Te Heuheu Tukino, the present head chief of Taupo.

Tama-te-Kapua wandered wide and far over the face of the Long White World, and at last made his home on the bold mountainous headland which the pakeha calls Cape Colville, guarding the Hauraki Gulf and its cloud of islands. Here Tama' died, and here his sons buried him, on the forested ridge of Moehau. On the lofty mountain-top was the chieftain laid to rest, and his sons as they performed the last rites said:

"Let him slumber here, where his spirit can gaze far over the ocean and over the land of Ao-tea-roa. And the winds that sweep across the Great Ocean of Kiwa, they shall ever sing his oriori, his wild lullaby."

And to this day the mountain-cape where the Captain of the Arawa was buried is called by the Maoris Te-Moe-hau-o-Tama-te-Kapua (Tama's Windy Sleeping-Place). 


\section{XVIII}

\section{TRADITION-TAMA-TE-KAPUA}

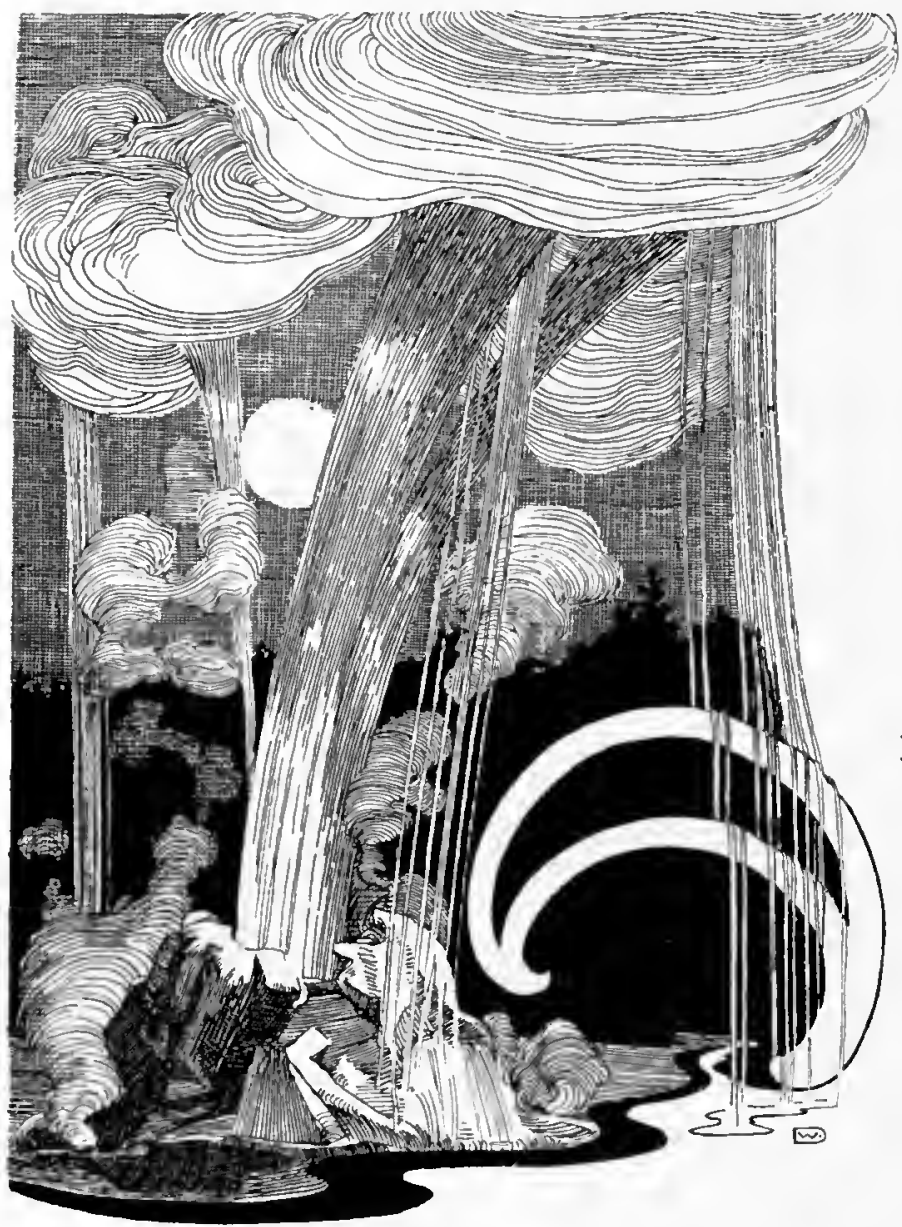

LONG a narrow path through the flowering manuka-shrub led Ngawai; round groaning, rolling, bursting, and steaming mudcraters wound the path, and steam hissed everywhere from out the ground-now on to the larger crater-basins full of boiling water, green, blue, white, and always wonderfully transparent. Out of the middle of the basins rose vast boiling columns out of the unmeasurable depth to the surface, there to burst, bubbling and boiling. A beautiful but terror-

inspiring spectacle are these crater-pools: silent, heartless, death-bringing, boiling from all beginning-from the time that Ngatoro-i-Rangi had called them from Hawaiki by his incantations: boiling, boiling, boiling; crowned with a thin cloud of steam, framed by the dripping, overhanging manuka-bushes.

Pitiless, eternal water-graves are these dark-green boiling seas, and the everlasting gargling of the water is like a death-song of lost souls hovering over them.

Dizzily narrow now led the path between two craters. Silently steamed the large basin to the right, its neighbour gargled and bubbled. Suddenly, as if by enchantment, the gargling water disappeared, and a moment afterwards shot a majestic column of water from out of the funnel, the air filling with vast clouds of steam. The whole column then broke in itself together, roaring and splashing; the boiling water overfowed the Geysercrater and filled the large steaming basin, which is only by a thin wall separated from the Geyser, with a fresh supply of hot water in which the Maoris and their white friends enjoy their bath, their chat, and their smoke, especially when the winds blow down from the snowfields of the mountains.

During the night the geysers groaned and burst and splashed all around: the noises accompanied the stories of the old friend-sometimes interrupting his murmurings, and sometimes lending power and truth to his words. 
TRADITION-TAMA-TE-KAPUA

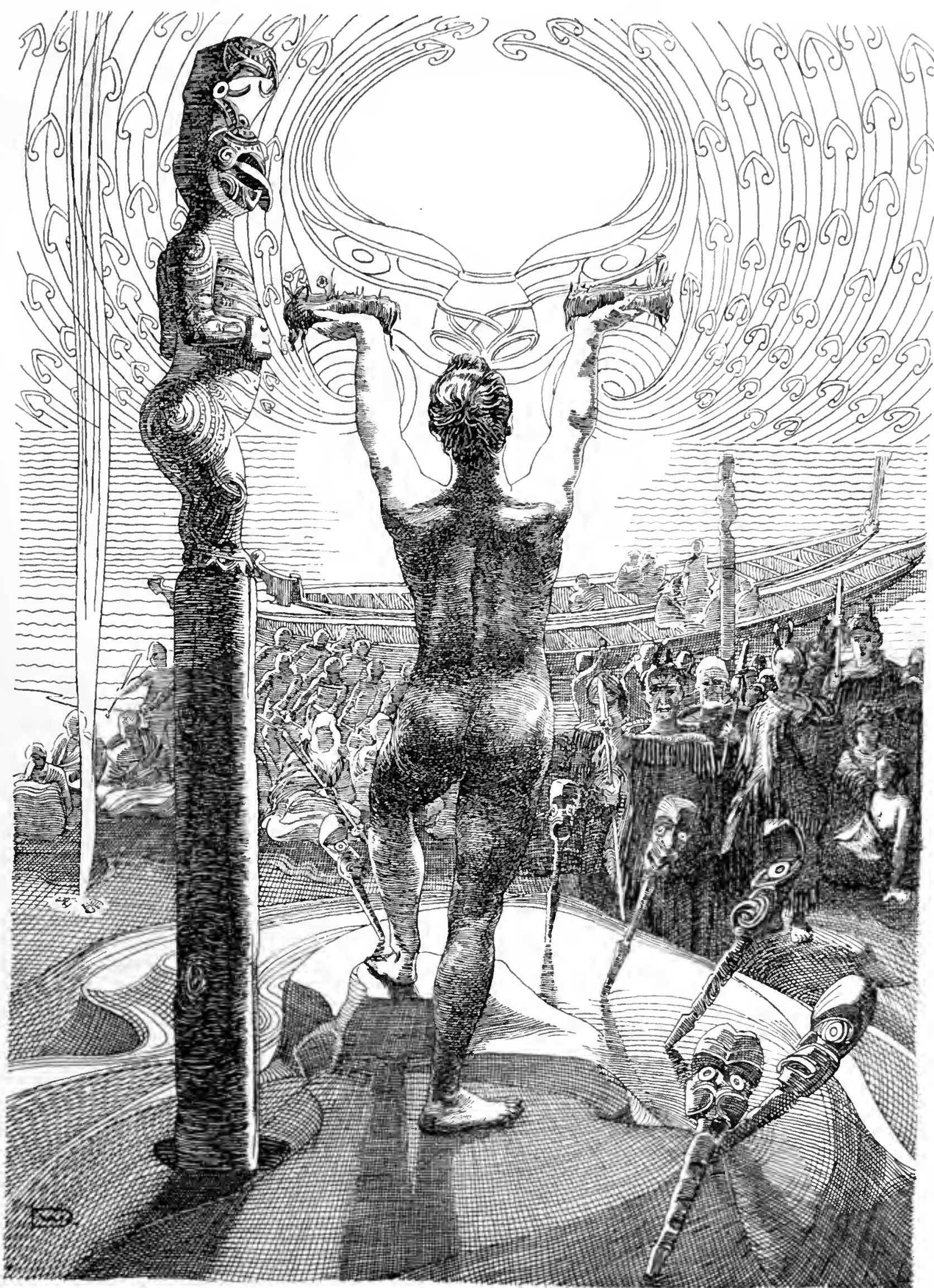




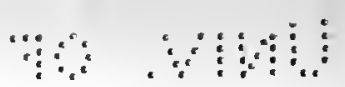

"... 

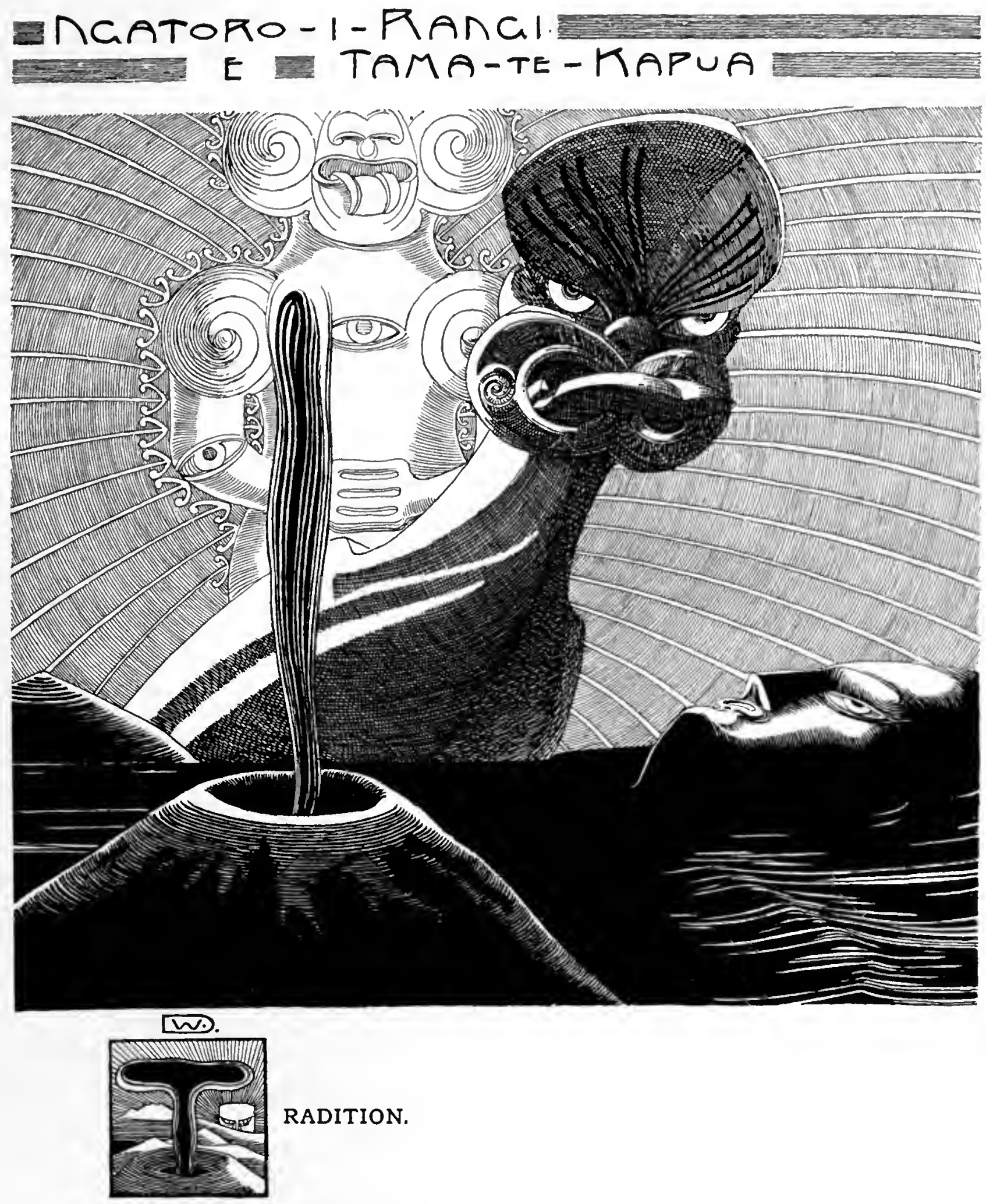

Ngatoro-i-Rangi is the Sun.

Tama-te-Kapua, the cloud invites the Sun to travel in his canoe, and Ngatoro-i-Rangi, coming from the east, follows the invitation and brings his wife, the Earth; for with the rising of the Sun out of darkness rises also the Earth.

During the journey Ngatoro climbs up to the Height of the Midday, tying the earth to him 


\section{ANCIENT LEGENDS OF THE MAORIS}

by his sun-rays; but Tama-te-Kapua unties the sun-rays which bind the earth to the Sun-the cloud flies over the earth-and takes her to his wife.

When Ngatoro now suddenly descends from on high, and bursts through the clouds, then is it too late: his rays are too feeble to tie them quickly again to the Earth.

Wrathful over the insult Tama-te-Kapua had done to him, Ngatoro now steers the canoe into the western precipice: the Sun is setting, and night swallows the canoe; and in vain does Tama-te-Kapua call for help from Ngatoro: everything is swallowed in darkness. But at last Ngatoro takes pity and saves the canoe: the Sun ascends again in the East, and steers the canoe against the West, to Ao-tea-roa. Far from Hawaiki now they landed.

Ngatoro takes possession of the land.

Wherever he ascends a hill, he stamps water out of the ground, and he puts the fairies, the Patu-paiarehe, upon the hills.

At last he ascends Tongariro, but his companions, whom he had left behind, saw that he became paler and paler as he reached the summit of Tongariro: the sun was frozen in the ice-cold atmosphere of the sacred mountain. At last, nearly dead, Ngatoro offers incantations to the gods at Hawaiki, and they send the fire to him.

It came through the paths of the Lower World and it burst through the earth on many places: at Roto-ehu, Roto-rua, Tarawera, and at many more places; but at last it ascended Tongariro, and created a volcano, and the fire and heat of the volcano saved Ngatoro-i-Rangi from a frightful death.

"Ngatoro-i-Rangi, my listener is the ancestor of the tribe of the Ngati-tu-wharetoa; we all are the descendants of Ngatoro-i-Rangi, and the sacred Tongariro is the guardian of my people."

Out of a wonderful spectacle of colours springs the new day into life.

The rising sun condenses the steam which is hanging, a large white cloud, over the landscape. Like granades are the geysers shooting into the mass of steam, and from everywhere is steam ascending thickening the silvery mass, which hangs swaying and broadening, and bordered with a golden rim, over our heads. Under the cloud glitters on the near hilltops the fresh fallen snow.

Now the heart of our old friend feels also joy and happiness.

On the edge of the warm crater basin he squats, covered in his mat, and looking far into the beautiful day, he commenced his last narrative-

"The bursting open of the gates of heaven" - so finished the old Tohunga his last song of creation-"was the work of Tamatea.

Dim was the light at first, but faster and more powerful became the blows of Tamatea upon the hangi (oven) in which all that was left of Tu-taka-hina-hina, a mighty ancestor of the Maori people, was roasting; and at last his blows burst the gate that closed in the days. And day came, and the full and long day came. The people of the world, now freed from darikness, looked around, and they could see how many had died during the everlasting darkness; and they could see how very few survived.

At last they saw with wonder how Tamatea, instead of Tangaroa, now took the Dawn of Morning in his keeping, and they knew that the time of the Many Days had come, and they cried full of joy and gladness: "Truly, Tamatea, this is the Dawn of our days!'"

Then the old friend pointed with a bony finger towards the Sun and spoke no more. 


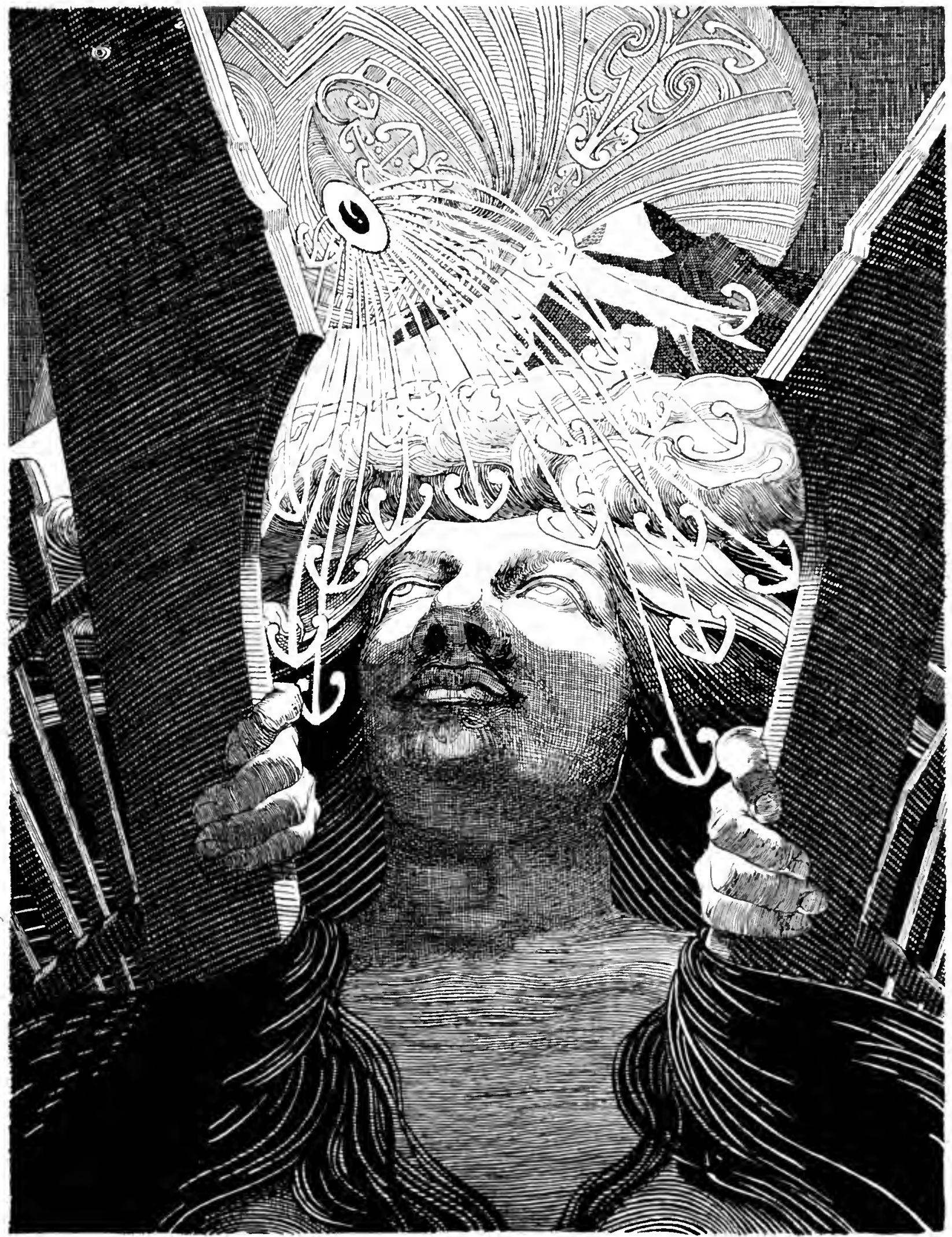




\section{XIX}

\section{A TANGI}

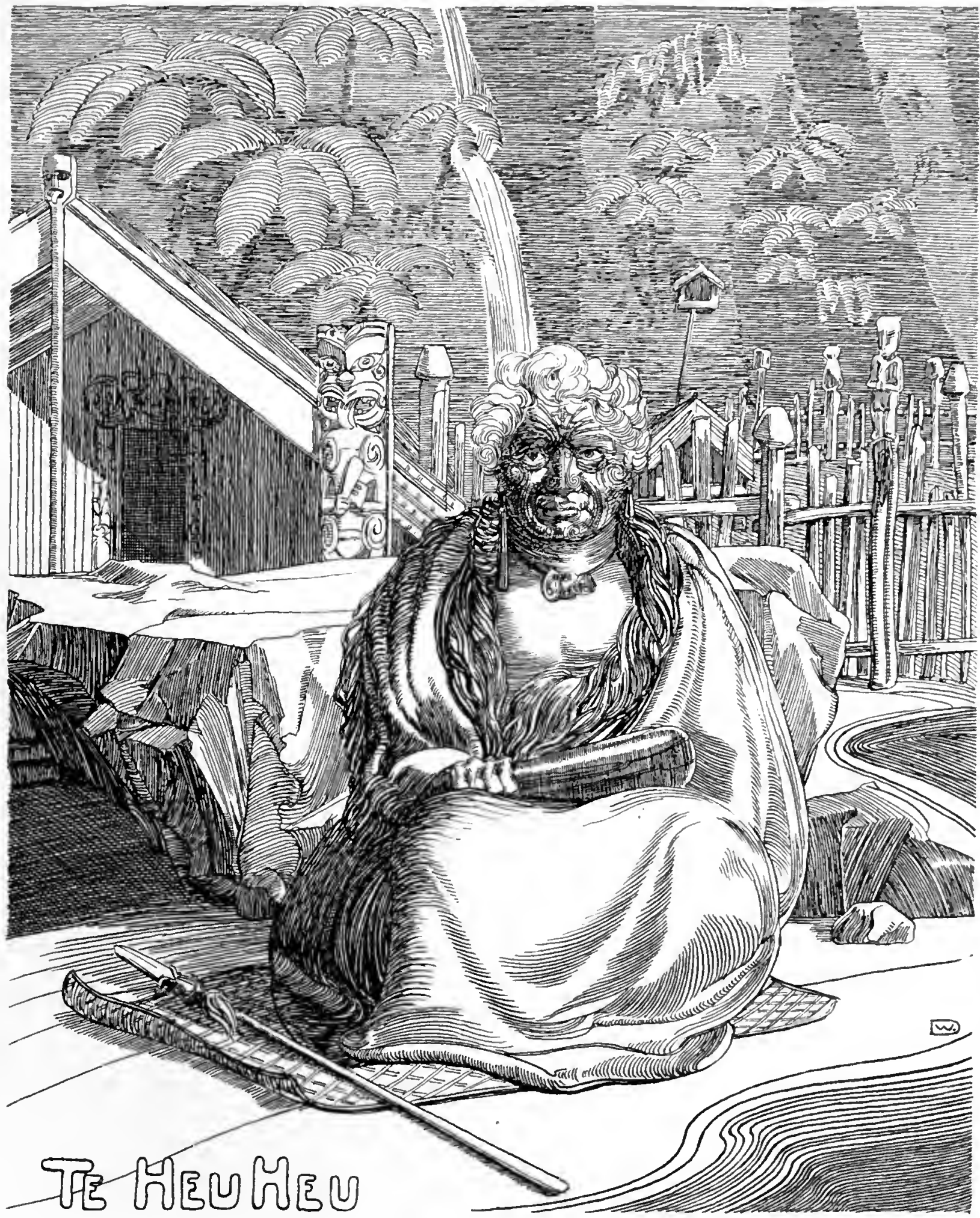





\section{A TANGI}

Like a filled sponge is the air lying over the pa, heavy and sorrowful-filled with desolate cries. Dismal wails issue from the groups which surround the dead chief, men and women howling, dancing, and distorting their faces.

The wailing lies like a cloud upon the earth, and hangs like fog around the groups. A sharp shriek pierces the air, or a shouted sentence in honour of the dead chief cuts the fog; and again everything unites into a monotonous, heart-breaking lament.

The dead chief was a Rangatira-Tohunga, and deep is the sorrow of his people from the mountains and his people from the lake. The women of his next relatives cut their breasts with sharp-edged shells, bleeding, and howling in their pain and sorrow.

Tribe upon tribe nears with dismal lament: all are received by the old women with the long-drawn, piercing cry of welcome to the Tangi. The women march in front; they have flowers wound around their heads, and wave flowers and twigs and leaves in their outstretched arms up and down, up and down-a sign of sorrow. Crying and sobbing follow the men, whose heads are bent and whose gestures betoken the deepest grief-warlike figures, with tattoed faces bestrewn with tears.

In long lines they approach. Canoe after canoe brings ever new hapus (parties), and each approaches in a long line loudly howling: louder and louder grow the howls till the hapu stands before the dead chief, who is covered with the red feather-mat of his rank; and there the whole mass of people is uniting in terrible dirge, dancing and distorting their faces, in which each new arrival joins. All nature seems to lament: the wide lake, the hills, the forests upon the hills and the cloud-covered heads of the mountains-all is united in grief.

Slowly night descends and covers the dirge in darkness.

Great was the mana of the dead Rangatira; terrible was his death; and great sorrow fills the hearts of his people.

The star-lit night is wonderfully clear, and looks down upon the dead chief in his red garment of the Rangatira, surrounded by the treasures of his people; in his hand the beautiful greenstone weapon, the famous mere Pahi-kaure.

Slowly the moon ascends over the murmuring waves of the lake, and streams peacefully her soft light down upon the thousands who are sleeping around her dead Rangatira.

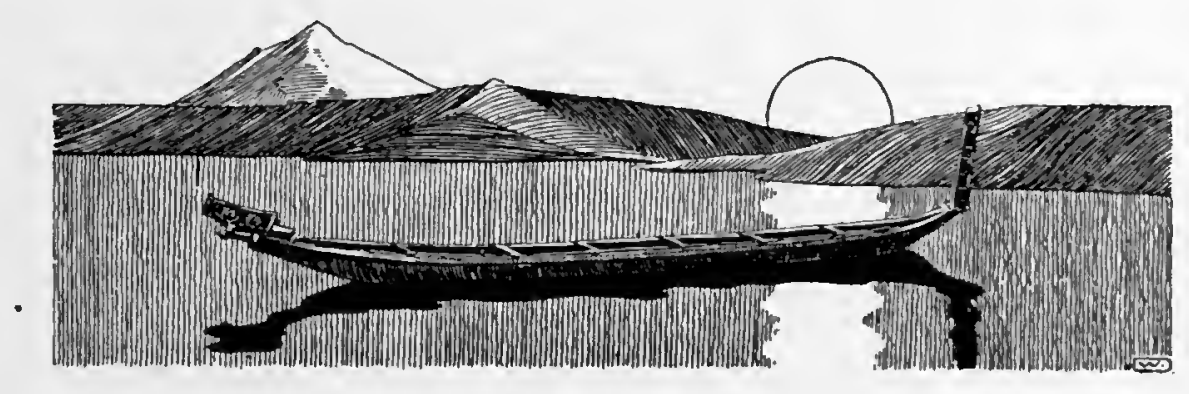




\section{ANCIENT LEGENDS OF THE MAORIS}

\section{TE REINGA, THE MAORI SPIRIT-LAND}

The empty forms of men inhabit there ;

Impassive semblances, images of air.-The Odyssey.

In the extreme north of the North Island of New Zealand is the Muri-whenua, the Land's End, where the never-resting surges thunder at the feet of the bare rocky capes, and the giant sea-kelp swirls in long snaky masses round the fabled gateway to the Maori spirit-land. For here is Te Reinga, otherwise called Te Rerenga-Wairua, or the Place where the Spirits take their Flight. Te Reinga is a long craggy ridge that dips down to the ocean, ending in a rocky point whence the ghosts of the departed take their final plunge into the realms of darkness and oblivion. The souls (wairua) of the dead, the moment they are released from their earthly tenements, travel northwards until they arrive at the Land's End of Ao-tea-roa. As they near the Reinga, crossing sand-dune and stony cliff, treading with viewless feet the wild precipices whose bases are ever licked ravenously by the wilder ocean, the spirits bethink them of their old homes. And they pause awhile on the wind-swept heights, and gaze backwards over the long and dreary way by which they came; and they wail aloud, and lacerate themselves after the fashion of the mourners of this world, with sharp splinters of volcanic glass (mata-tuhua), and in proof thereof these mata are to be seen there to this day by living man. They deck their heads with paréparé, or mourning chaplets of green leaves, and their weird, ghostly wails for the Land of Light they are leaving mingle with the melancholy voice of the ocean winds. The long flax leaves which spring from the rocky soil on these heights above the Reinga are often found knotted and twisted together in a peculiar manner. The pakeha says this is the work of the ever restless winds and eddying gales which sweep the Land's End. But to the Maori those knotted leaves are the work of the sad spirits of their departed, tied by the ghosts as they pass along to the gates of $\mathrm{Po}$, to show their sorrowing friends the way they took in leaving this world of day. And the waterfalls cease their sound as the ghosts flit by;

Trembling the spectres glide, and plaintive vent

Thin hollow screams, along the steep descent.

Down along the narrow ridge to the tideway they move, until they reach the ghostly leaping-place, tapu to the manes of the innumerable multitude of dead. Here grew a venerable pohutukawa tree, gnarled and knotty, with great ropy roots trailing to the tide. By these roots the spirits dropped to the sea, loosing their last grip of Ao-tea-roa to the dirge of the screaming sea-birds and the moaning waves. Below, the tossing sea-kelp opens a moment to receive the wairua, and then the dark waters close over them for ever. This is the Tatau-o-te-Po, the Door of Death, which is the entrance to the gloomy Kingdom of Miru, the Goddess of Eternal Night.

Many an Ossianic concept, many a weird and poetic fancy, is woven by the Maoris round this haunted spot. This is a fragment of an ancient lament for the dead, sung to this day at Maori tangis :

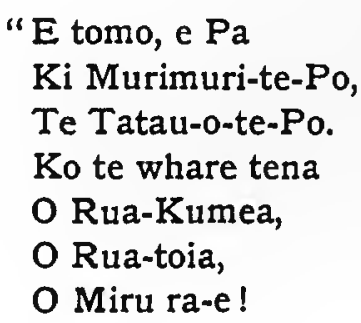


TE REINGA, THE MAORI SPIRIT-LAND

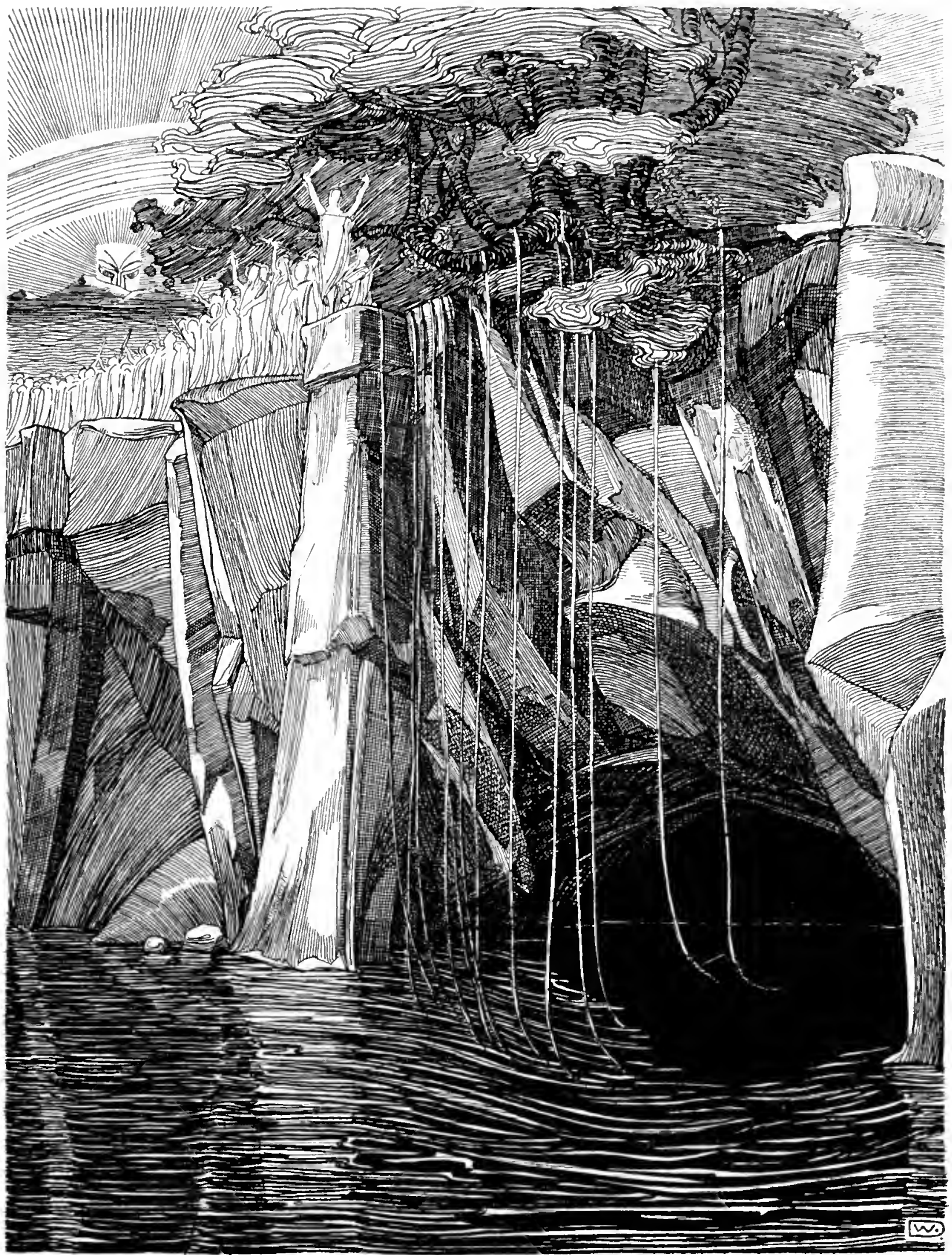



O tuhouropunga,

O kaiponu-kino.

Nana koe i maka

$\mathrm{Ki}$ te kopae o te whare $\mathrm{i}$ !"

("Enter, oh sire,

The gates of that last land,

So dread and dark;

The Gates of the Endless Night.

For that is the dwelling

Of Rua-kumea,

Of Rua-toia,

Of the grim goddess Miru,

The ever-greedy one.

'Tis she who hurleth thee

To the deep shadows of her gloomy house.")

And, again, the tribal bards, lamenting over their dead, chant this centuries-old poem :

"Now like an angry gale,

The cold death-wind pierceth me through.

O chiefs of old,

Ye have vanished from us like the moa-bird,

That ne'er is seen of man.

O lordly totara-tree!

Thou'rt fallen to the earth,

And naught but worthless shrubs remain.

I hear the waves' loud tangi

On the strand of Spirit Land,

Where souls, borne from this world of light,

Cast one last look behind.

The rolling seas surge in at Taumaha

Singing their wave-song for the dead

Who have forever vanished from our eyes." 

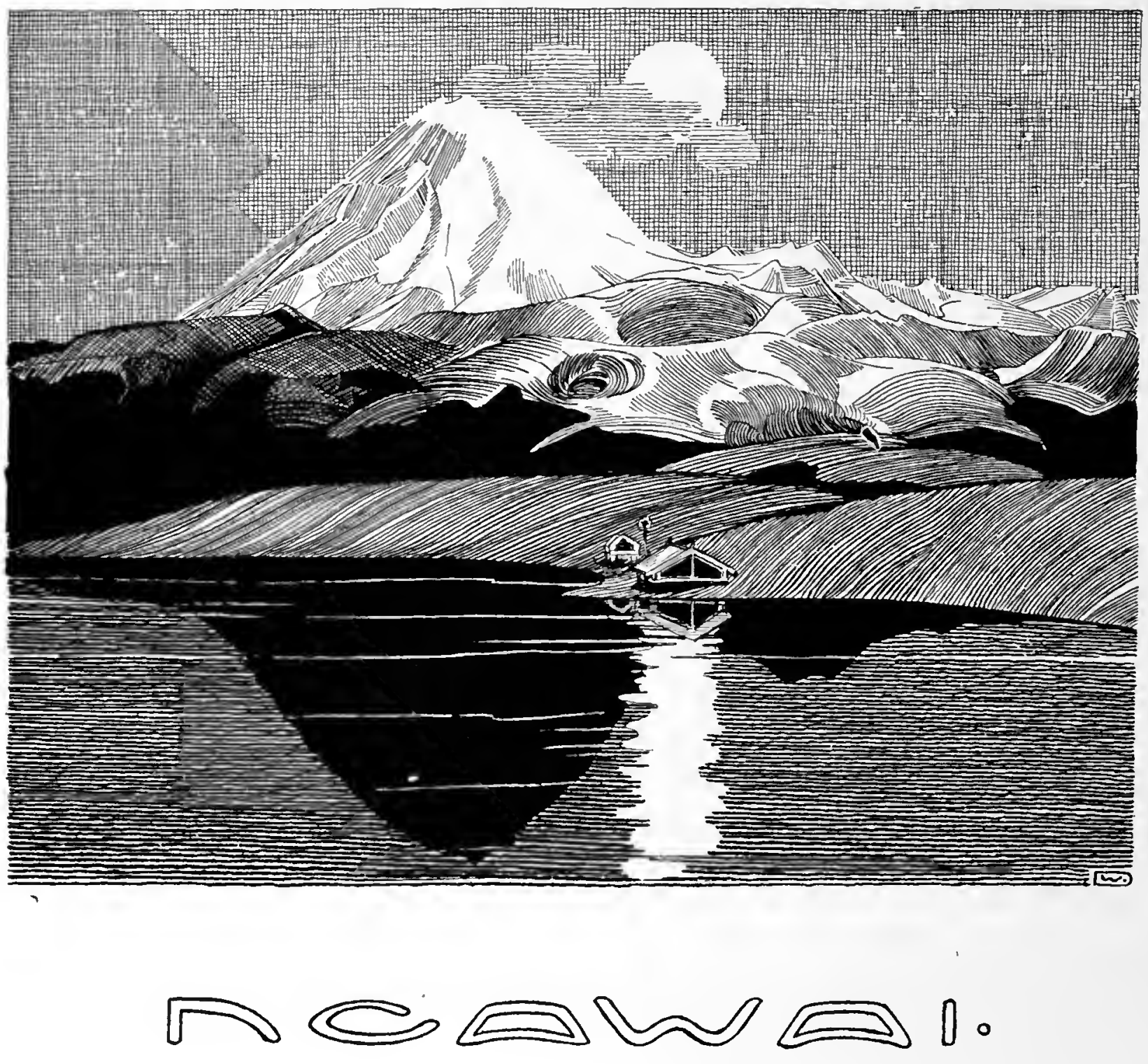

Dreamily is Ngawai staring into the embers, whilst the pale new morning is crawling through the spaces between the fern-stems which form the walls of the mountain-whare (hut).

Cold and pale at first appear the long stripes painted over the floor, till they change slowly into warmer and more glowing colours, lighting up the calabashes, the nets, the paddles, and the mats, which hang on the walls smoke-blackened under the raupo roof. The stripes of daylight are able, too, to light up Ngawai's eyes, which stare into the nearly burnt-out embers. More fiery glow the stripes, and suddenly they flood the whare with wonderful golden light: it is pure gold, through which, like music, the blue smoke ascends to the roof. Now the Sunshine pours in at the door, and with it the wonderful picture of the mountain-lake, reflecting the mountain giants, to the astonished eye. And in all the beautiful world life commences again with laughter and happiness-the laughter and happiness of the parting day.

Slowly is the sun wandering his way in the skies; up to the height of midday he wanders; the shades grow longer, and Rangi-o-mohio, a very old woman, the daughter of the famous Rangatira Te Heu-heu, is still relating:

"Listen: A great procession is ascending with much noise and shouting and frolic the 


\section{THE BURIAL OF TE HEU-HEU ON TONGARIRO}

barren wilderness around the stone-body of Tongariro-a great procession of Tohungas, warriors, women, and children.

Ah, Iwikau the Rangatira is leader, and they carry the bones of Te Heu-heu, my father.$\mathrm{Ah}, \mathrm{Te} \mathrm{Heu}-\mathrm{heu}$, he was my father! Ah, with his bones we wander and crawl and climb over the lonely wilderness. Ah, he was the Rangatira over the lands-but, my son, look upon the greatest Rangatira of all the lands: look upon the Tongariro-tapu!"

Ngawai listens to the narrative of the old Rangi-0-mohio whilst her eyes are gazing upon the sacred Tongariro. The moon has risen over the lake, and a fine silvery gleam is glittering upon the snow of the mountain, which is sending its beautiful column of silver high up into the skies. Then once more Ngawai looks sorrowfully back, and goes on her way to her people in the distant pa.

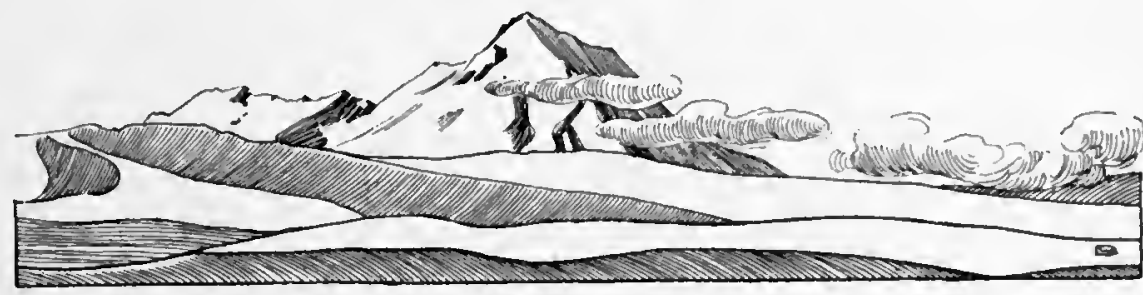

THE BURIAL OF TE HEU-HEU ON TONGARIRO

This is Rangi-a-mohio's story:

Iwikau, the brother of the dead Rangatira Te Heu-heu, and chief now over the tribe of the Ngati-tu-wharetoa, is the leader of a large procession of sorrowing, weeping people of the tribe. The four greatest warriors of the tribe carried the carved box which contained the bones of $\mathrm{Te} H e u-h e u ;$ it was painted red, and adorned with white albatross-feathers.

The whole tribe had decided to give their dead Rangatira the mightiest burial-ground in all Ao-tea-roa-the crater of Tongariro-tapu 1

Truly, the mountain Tongariro shall swallow the bones of the Rangatira, that they never may fall in the hands of man-perhaps enemies.

The sharp-edged coke-rocks cut the feet of the bearers, and the sulphur in the air is the deadliest foe to frolic-and what can be properly done without frolic in Maoriland? The feet of the bearers begin to bleed, the incantations of the Tohungas grow weaker; less overbearing, too, become the songs of defiance which Iwikau is shouting to the gods: silence and ghostly fright fall upon the multitude.

Deeper now are the precipices, steeper the rocks, and hellish the sulphurous fumes; but high above still towers the crater, the summit of Tongariro, the mighty grave of the Rangatira! The sacred mountain shall swallow the bones of the sacred chief-as the base of the mountain, in a frightful landslip, has swallowed his life!

Great is the conception, and bravely they try to carry it into effect beneath the mighty 


\section{ANCIENT LEGENDS OF THE MAORIS}

column of steam and sulphur which Tongariro is streaming out and which the heaven is pressing down again upon the people, in wrathful defiance of its sanctity.

Distant thunder rolls, shaking the ground, and the sulphur-fumes press fiercely beneath the broadening steam-column. Hard and heavy breathe the bearers; terror at the temerity of the undertaking, which violates the sacredness of the mountain, grows in the heart of their leader. .

The vast world stretches all around, and the people who surround the dead Rangatira seem tiny and powerless as the mountain defends his sacred crater with mighty bursts of steam and smoke and rolling thunder and suffocating fumes. Overawed by terror the strength of the bearers fails : they let fall their burden upon a rock; the hearts of the bravest are trembling.

The sanctity of Tongariro-tapu cannot be violated; no, not even by the sacred bones of the Rangatira; and fear grows overpowering beneath the still high-towering, angry cratersummit.

None dares touch the remains of $\mathrm{Te}$ Heu-heu again; one and all let them be where they are, upon the rock, overtowered and defended by the majestic summit, with its rolling, thundering, steaming crater - and down they tumble, down, down, helter skelter, in wild and fearful fright they run, a shouting, shrieking body of men, possessed by overpowering terror of the sacred giant. Down, down.

But high up in the sacred regions of Tongariro lie bleaching the bones of the greatest Rangatira of the mountain people-

Maui Pomare, M.D., the grandson of a famous chief, gave me, at parting, this lament composed by the wife of his ancestor:

"Behold! far off, the bright evening star

Rises-our guardian in the dark,

A gleam of light across my lonely way.

Belov'd, wer't thou the Evening Star,

Thou wouldst not, fixed, so far from me remain.

Let once again thy spirit wander back,

To soothe my slumbers on my restless couch,

And whisper in my dreams sweet words of love.

Oh! cruel Death, to damp that beauteous brow

With Night's cold softly falling dews.

Rau-i-ru, Keeper of Celestial Gates, *

There comes to thee a lovely bride

Borne from me on Death's swollen tide.

Belov'd, thy wandering spirit now hath passed

By pendant roots of clinging vine

To Spirit Land, where never foot of man

Hath trod-whence none can e'er return-

Paths to the Gods which I not yet have seen.

Belov'd, if any of that host of Heaven

Dare ask of thee thy birth or rank,

Say thou art of that great tribe

Who, sacred, sprang from loins of Gods.

As stands lone Kapiti, a sea-girt isle,

And Tararua's solitary range,

So I to-day stand lonely midst my grief.

My bird with sacred wings hath flown away

Far from my ken, to Spirit Land.

* The god who receives the spirits. 
THE BURIAL OF TE HEU-HEU ON TONGARIRO

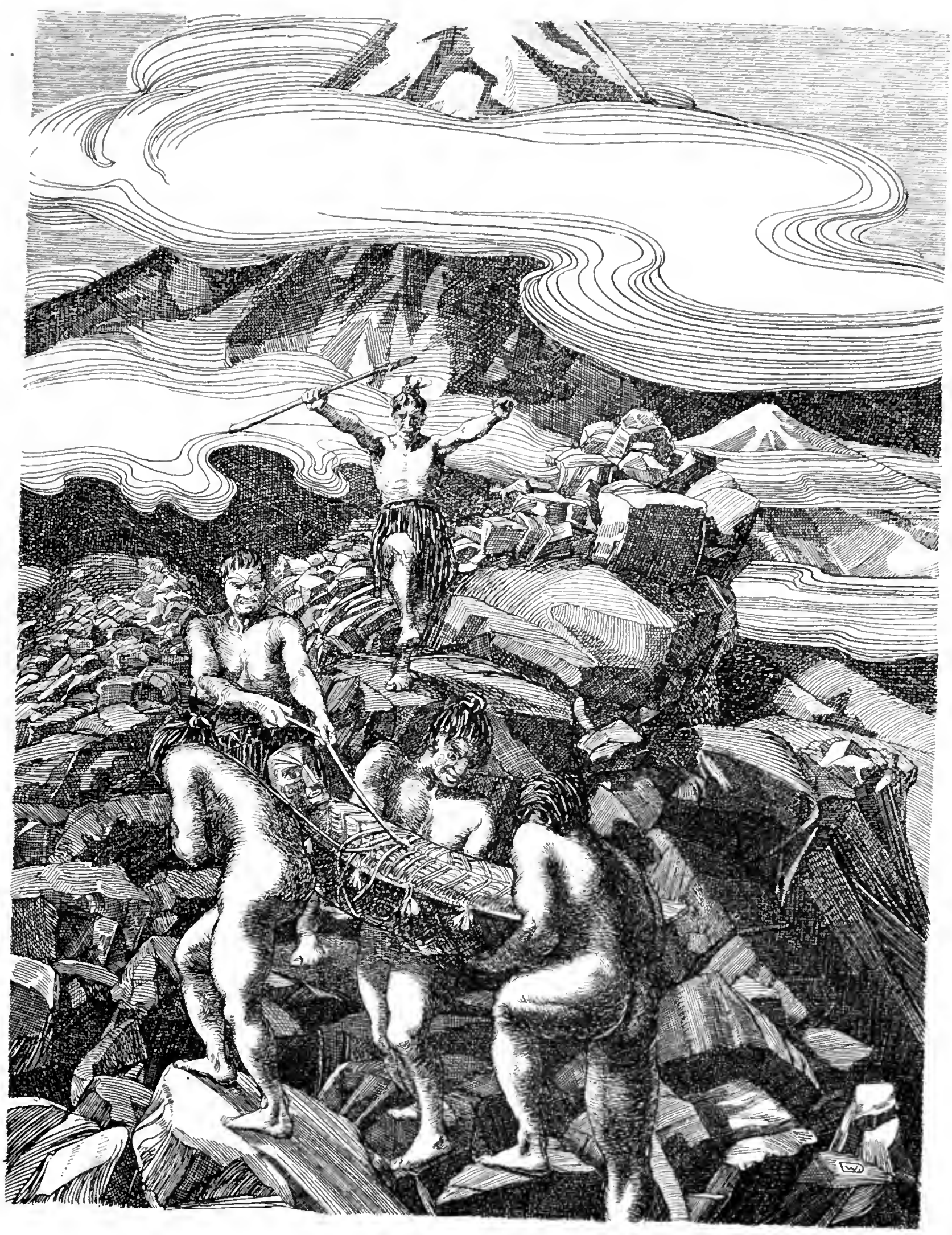



THE BURIAL OF TE HEU-HEU ON TONGARIRO

I would I were a Kawau, resolute

To dive into the inmost depths of time,

To reappear at my beloved's side

Amidst the throng upon the further shore.

Belov'd, I soon will join thee there!

I come! Await me at the gates!

My spirit frets; how slow is time."

THE END

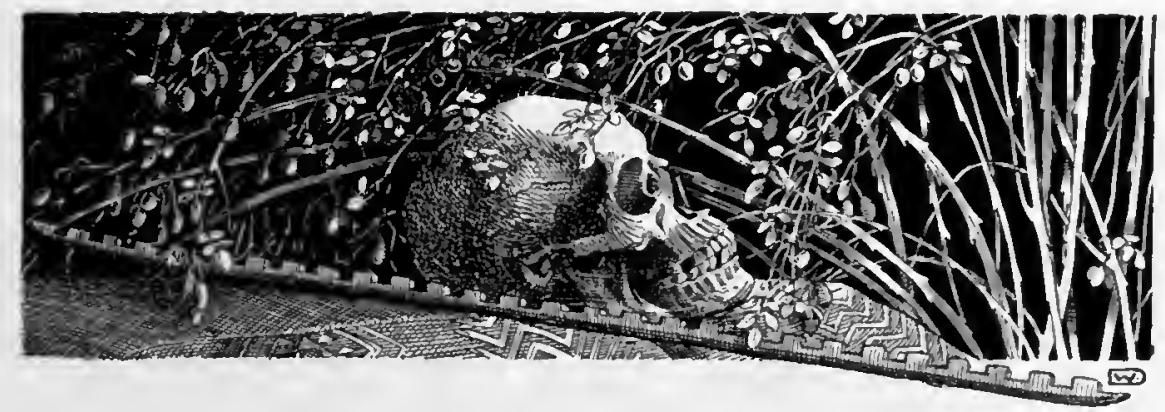



Printed at

The Edinburgh Press 9 and II Young Street 



RETURN TO the circulation desk of any

University of California Library

or to the

NORTHERN REGIONAL LIBRARY FACILITY

Bldg. 400, Richmond Field Station

University of California

Richmond, CA 94804-4698

ALL BOOKS MAY BE RECALLED AFTER 7 DAYS

2 -month loans may be renewed by calling

(415) 642-6233

1 -year loans may be recharged by bringing books to NRLF

Renewals and recharges may be made 4 days prior to due date

DUE AS STAMPED BELOW

SEP 081990

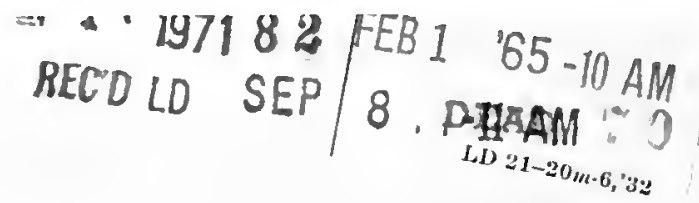


U.C. BERKELEY LIBRARIES

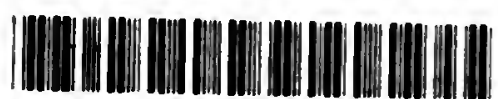
c00607454l 
